Historic, Archive Document

Do not assume content reflects current scientific knowledge, policies, or practices. 



\section{New Books}

\section{Interesting and Valuable Reference Works by Famous, Practical Men.}

Orchardists, Nurserymen, Florists, Gardeners and amateur growers will find a reliable text book to be their best guide, and greatest aid to success.

We have carefully selected the following most practical works on the subjects treated.

All books postpaid at following prices:

Apple Culture, Field Notes on, Bailey, 88

Binding Price

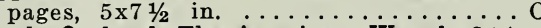

Apple Orchard, The American, Waugh, 214 pages, $5 \times 7 \frac{1 / 2}{}$ in.

Art of Propagation, Jenkins, 31 pp., $6 \times 9$ in $P$ Asparagus, Hexamer, 116 pages, $5 \times 7 \frac{1}{2}$ in. $C$ Beautiful Flower Garden, The, Matthews, 186 pages, $5 \times 7 \frac{1 / 2}{2}$ in. ........... $\mathrm{P}$

Blackberry and Raspberry Culture, Littooy,

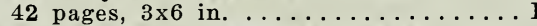

Bulbs and Tuberous-Rooted Plants, Allen, 312 pages, $5 \times 7$ in. ............

Bush Fruits, F. W. Card, 538 pages ....

Carnation Culture, American, Lamborn, 175 pages, $51 / 2 \times 8$ in. . ...................
Chrysanthemum, The, Herrington, 160

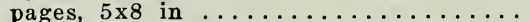
Cranberry Culture, White, 131 pages, 5x

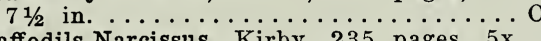
Daffodils-Narcissus, Kirby, 235 pages, $5 \mathrm{x}$ $71 / 2$ in. . . . . . . . . . . . . $\ldots \ldots \ldots$ pages, Dwarf Fruit Trees, Waugh, 125 pages, Ferns, and How to Grow Them, Woolson, 156 pages, $5 \times 7 \frac{1 / 2}{2}$ in. ...........

Fertilizers, Gregory, 137 pages, $5 \frac{1 / 2}{2}$

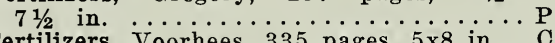
Fertilizers, Voorhees, 335 pages, $5 \times 8$ in...

Floriculture, Practical, Henderson, 325

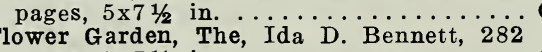

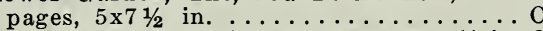

Fruit Garden, Barry's, 516 pages, $5 \times 71 \frac{1}{2}$ in. $\mathrm{C}$

Fruit Grower, The Practical, Maynard, 128

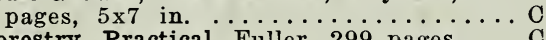

Forestry, Practical, Fuller, 299 pages ....

Fruit Growing, The Principles of, Bailey,

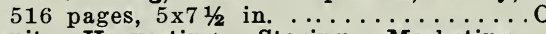

Fruit, Harvesting, Storing, Marketing, Waugh, 224 pages, $5 \times 7 \frac{1 / 2}{}$ in. ......

Fungi and Fungicides, Weed, 228 pages,

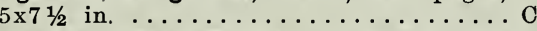

Garden and Farm Topics, Henderson, 244

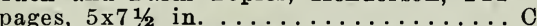

Gardening for Pleasure, Henderson, 404

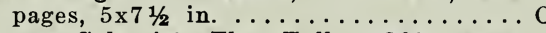

Grape Culturist, The, Fuller, 282 pages,

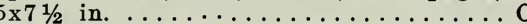

Greenhouse Construction, Taft, 210 pages

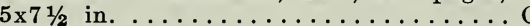

Greenhouse Management, Taft, 382 pages,

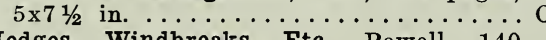

Hedges, Windbreaks, Etc., Powell, 140 pages, $5 \times 7$ in. ... ...........

Home Floriculture, 300 pages, $5 \times 7$ in.... C

Horticulturist's Rule Book, Bailey, 312 p..C
Note-C indicates cloth; P, paper cover.

Binding Price

How to Plan the Home Grounds, Parsons, 249 pages, $5 \times 8$ in $\ldots . . . . . . .6$

Injurious Insects of the Farm and Garden, Treat, 296 pages, $5 \times 7 \frac{1 / 2}{\text { in } \ldots . . . . . ~} 1.60$

1.15
30 Insects Injurious to Fruits, Saunders, 436 pages, $5 \times 8$ in. .............

Insects and Insecticides, Weed, 334 pages, $5 \times 7 \frac{1 / 2}{2}$ in. . . . . . . . . . . . . . . . . Irrigation for the Farm, Garden and Orchard, Stewart, 276 pages, $5 \times 71 / 2$ in ... C

Land Draining, Miles, 199 pages, $5 \times 7 \frac{1}{2}$ in. C Landscape Gardening, Maynard, 338 pages,

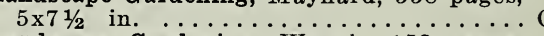

Landscape Gardening, Waugh, 152 pages,

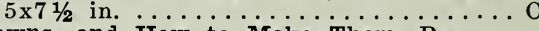

Lawns, and How to Make Them, Barron,

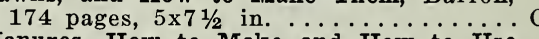

Manures, How to Make and How to Use Them, Sempers, 218 pages, $5 \times 71 / 2$ in. ...P

Manure, The Bommer Method of Making, 86 pages, $6 \times 9$ in. ............ $\mathrm{P}$

Nursery Book, The, Bailey, -365 pages, $5 x$ 7 in $\ldots \ldots \ldots \ldots \ldots \ldots \ldots \ldots \ldots \ldots \ldots \ldots$ Nut Culturist, The, Fuller, 289 pages, $5 x$

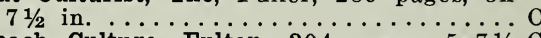

Peach Culture, Fulton, 204 pages, $5 \times 71 \frac{1}{2} \mathrm{C}$

Propagation of Plants, Fuller, 349 pages,

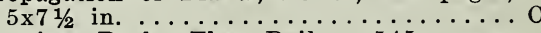

Pruning Book, The, Bailey, 545 pages, $5 \times 7 \frac{1 / 2}{2}$ in. $\ldots \ldots \ldots \ldots \ldots \ldots \ldots \ldots \ldots \ldots \ldots$

Raspberry and Blackberry Culture, New, Littooy, 42 pages, $3 \times 51 \frac{1}{2}$ in. ....... Rhubarb Culture, The New, Morse, 130 pages, $5 \times 7 \frac{1 / 2}{}$ in. . . . . . . . . .

Rose, The, Ellwanger, 310 pages, $4 \frac{1 / 2 \times 61 / 2}{2}$

Rose, The Book of the, Foster-Melliar,

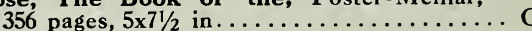

Rose, Parsons on the, 211 pages, $5 \times 7 \frac{1}{2}$ in. $\mathrm{C}$

Roses and How to Grow Them, 189 pages,

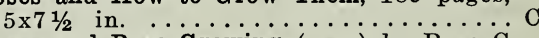

Roses and Rose Growing (new) by Rose $G$ Kingsley, 163 pages ...........

Small Fruit Culturist, Fuller, 289 pages

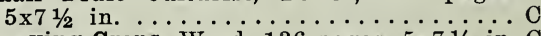

Spraying Crops, Weed, 136 pages, $5 \times 71 / 2$ in. $C$ Strawberry Culture, The A B C of, Terry \& Root, 235 pages, $5 \times 6$ in. ......... P $\quad .50$ Strawberry Culturist, The Illustrated, Fuller, 59 pages, $5 \times 7$ in. ...........

Sweet Potato Culture, Fitz, 86 pages, $5 \mathrm{x}$

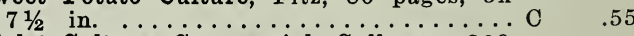
violet Culture, Commercial, Galloway, 239 pages, $5 \times 71 / 2$ in ...............

Violets, How to Make Money Growing, Saltford, 45 pages, $5 \times 6 \frac{1 / 2}{2}$ in. ....... Water Lilies and How to Grow Them, Conard \& Hus, 228 pages, $5 \times 7 \frac{1 / 2}{2}$ in. ..... C 1.10

\section{Bees In Orchards Are An Imperative Necessity}

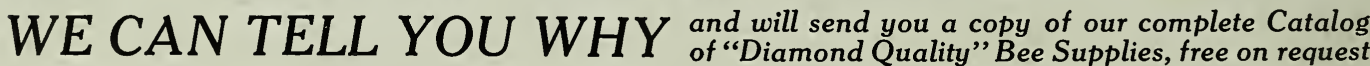

\section{GUARANTEE OF GENUINENESS}

While we exercise the greatest care to have all our stocks true to name, and hold ourselves in readiness on proper proof to replace all trees, etc., that may prove untrue to label free of charge, or refund the amount paid, it is mutually understood and agreed to between the purchaser and ourselves, that our guarantee of genuineness shall in no case make us liable for any sum greater than that originally received for said trees, etc. that may prove untrue. 


\section{AUTUMN CATALOG}

Bulbs, Roses, Fruit, Shade and Ornamental Trees and Flowering Plants

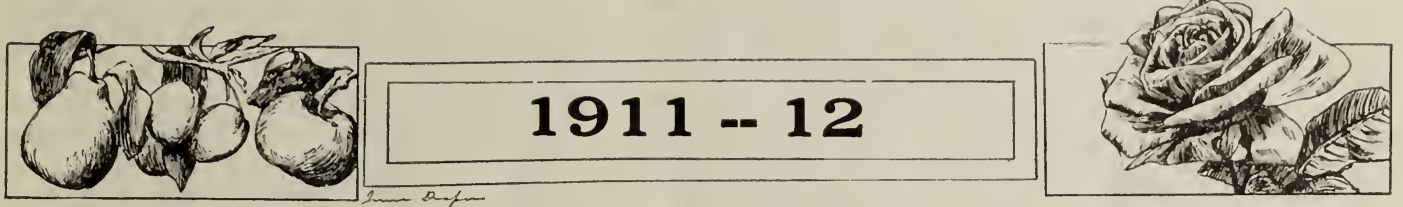

THE BEAUTY AND VALUE of planting-improvements, do not lie in their extent or the amount expended upon them, but in their tasteful and appropriate relation to their surroundings and to the selection of suitable varieties that, where desirable, will give permanency.

To assist you in your selection-which is a matter of first importance-we list in this Catalog only such standard varieties and novelties of real merit as experience has proven will give satisfaction.

Our Dutch, French, Japanese and Native Bulbs are the choicest "Top-root" size from the most reliable growers-not the small, immature mail order stock which is usually offered.

Oregon Roses are world famous and we are justly proud of our two-year field grown plants, which include the latest novelties from the most famous Irish, English and European growers. We list only those that are most desirable, but can supply any variety in commerce, guaranteed true to name.

Fruit and Ornamental Trees, Shrubs and Berry Plants are grown near Portland and in no other country do nursery stocks grow to such perfection, and the Western varieties of fruits and berries originating in Oregon and the Pacific Northwest have no equals in their various classes, being a revelation to orchardists from other sections.

Ferns, Palms, House Plants, Perennial Border and Bedding Plants of our own growing, fine healthy specimens, the most beautiful and useful varieties, can be supplied in season in unlimited quantities.

Tell us your Planting Plans.-If in doubt as to variety, or if special effects are required, our experience may prove helpful and save you money and disappointment. Our facilities for serving you promptly are unexcelled and your orders or inquiries will have immediate and courteous attention.

PORTLAND SEED COMPANY.

\section{IMPORTANT-.-PLEASE READ CAREFULLY}

When To Order.-We issue this Catalogue in September, but customers can order at any time and goods will go forward in season, as follows:

Flowering Bulbs.-We are direct importers from Holland, France, Bermuda and Japan; stocks begin to arrive in August, most deliveries being complete by December 1st, except such bulbs as Cannas, Dahlias, Gladioli, Tuberous Begonias, etc., which are not ready until after February 1 st.

Orders should be placed early in the fall as late plantings do not give best results, but stock can bo supplied up to March 1 st. If you are not ready to plant bulbs when received, put them away in a cool, dry place and they will keep for weeks.

See Cultural Directions under the different headings for best time to plant.

Palms, House Plants, Etc.-Our importations of these arrive from December to May. During these months we have large and complete stocks, but we can generally furnish nice plants during the whole year. Palms and plants should be potted as soon as possible after arrival and watered well for a day or two so as to settle the earth round all the little fibrous roots.

Roses.-We are headquarters for Roses and guarantee all varieties true to name. In our list will be found the recent introductions of the world's great rose specialists, if there is a novelty of real merit we can supply it. Our large two year old field grown roses are ready for delivery from October until June, one year old mailing size from January to August. The earlier you set them out the better they will grow.

Fruit, Shade and Ornamental Trees and Shrubs.We ship these from October until June and recommend fall and early spring planting. Late plantings are successful if you water freely. If you do nof want to plant on arrival, dig a trench and "heel" your trees in. If the ground is frozen, put them in a cellar and keep the roots damp.

Mail and Express Charges on Bulbs.-Only Flowering Bulbs are prepaid at catalog prices. All other items F. O. B. Portland, unless otherwise stated.

Complaints or Praises.-If our goods and treatment please you, tell others; if anything is wrong, tell us quickly, so that we can make it right. Our best efforts will be given to filling all orders in a satisfactory manner.

Order early-it helps us to please you.

We never Substitute without permission from our customer. But as many items are sold out as the season advances, when requested, we will substitute varieties of equal merit maturing about the same season. But always labeled true to name.

NOTE.-WE CANNOT SEND GOODS C. O. D.-CASH MUST ACCOMPANY ALI ORDERS.

Of Our Oregon grown nursery stocks are strong, vigorous Trees and Plants - The best the world produces-Carefully selected, true to name, guaranteed free from disease and pests, and, in strict compliance with our State Horticultural Laws, are always inspected before shipping. 


\section{Bulb Planting Tables}

Number of Bulbs Required for Planting Different Sized Beds of Tulips or Hyacinths

Everyone can afford a bed of flowering bulbs. They bloom so early, make such hand some and showy displays, and require so little care that their general use is increasing each year. As the circular bed is the most popular and satisfactory, we use it as a basis to figure on. If you want a square or oblong bed the cultural directions of the different bulbs will give you the distance bulbs should be planted apart. The best effect in bulb beds is obtained by planting to solid colors, but if variety is wanted we would not advise you to select over two or three colors. Too many colors spoil the whole effect. A very satisfactory way is to plant a solid center with one or two of the outer rows of another color; a pleasing effect is obtained by dividing the bed into four sections, planting each in a separate color.

In ordering bulbs for the mixed beds and for the number contained in the two outer rows of different sized beds, refer to table below.

\section{No of Bulbs Required}

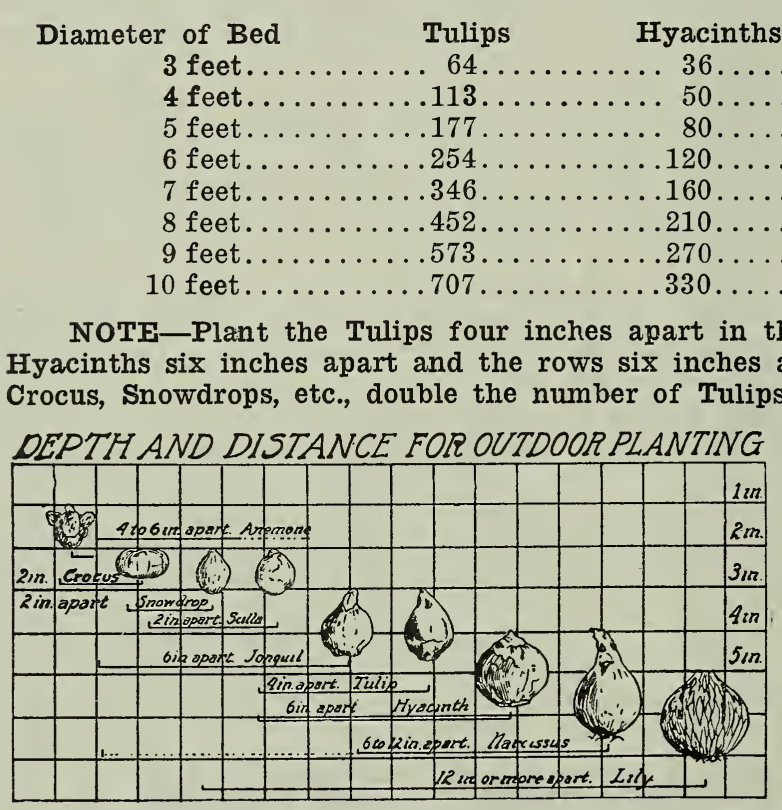

No of Bulbs Required for Two Outer Circles Only

\section{Tulips Hyacinths}

3 feet. . . . . . $64 \ldots \ldots \ldots \ldots 36 \ldots \ldots \ldots \ldots 50 \ldots \ldots \ldots$

$80 \ldots \ldots \ldots \ldots 87 \ldots \ldots \ldots 57$

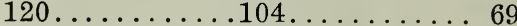

. . . . . . .

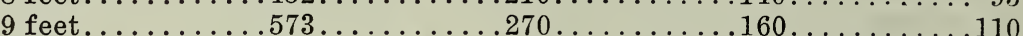

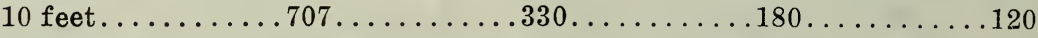

NOTE-Plant the Tulips four inches apart in the rows and the rows four inches apart. Hyacinths six inches apart and the rows six inches apart. Narcissi same as Hyacinths. For Crocus, Snowdrops, etc., double the number of Tulips. See chart below.

\section{HYACINTH GLASSES}

These are for Growing

\section{HYACINTHS AND NARCISSUS}

In water, see page 3

High or Low, Each, 20c; doz. $\$ 2.00$

The sooner Hyacinths and Daffodils are planted the better they will grow and force.

\section{Suggestions for Tulip Beds}

No. 1-Circular Bed of Vermillion Brilliant with edging of two rows of Chrysolora, yellow............... Cottage Maid, pink; second, Chrysolora, yellow; third, Artus, scarlet fourth, La Reine, white. This arrangement is effective with two colors, red and white being best.

No. 3-A Circular Bed of pleasing variety is made with Kaiserskroon scarlet edged gold, in center, Belle Alliance scarlet, next, then La Reine white, and on outside rows Chrysolora yellow.

No. 4-Bed in Three Sections or three rows of color; Crimson King, scarlet; Rose Grisdelin, pink; L'Immaculee, white.
No. 5-Bed in Three Sections or Rows; Joost van Vondel, cherry red with white stripe; Rose Grisdelin, pink; Yellow Prince, bright yellow.

No. 6-Double Tulips-Rubra Maxima, scarlet and $\mathrm{La}$ Candeur, white, give a fine showing, holding their form and lasting well.

No. 7 - Single May Flowering-White Swan, Gesneriana Spathulata, rich crimson, and Bouton d'Or, pure doep yellow, can be used in pleasing combination. They are tall growers ( 18 inches) and the best of their colors.

Solid Beds of Murillo, early double light pink, or Rose Grisdelin, early single. delicate pink, are very attractive.

Plant a shallow rooting annual in your Tulip bed, and you will not have a bare spot when the bulbs are gone. It also keeps the weeds down. Forgetmenots, Petunias, Pinks, Poppies, Verbenas, Candytuft, are a few of the best. Low growing perennials are also good, as they need not be disturbed. It is best not to lift Tulips each year. Leave them in the ground. They bloom better.

FLORISTS, GARDENERS and LARGE BUYERS of BULBS, should submit their Lists for Special Prices on the Number of Bulbs they Use. We can save You Money and Our "Diamond Quality" Bulbs will Give You Satisfaction 


\section{HYACINTHS}

ALL HYACINTHS ARE WELL ADAPTED TO POT CULTURE, OPEN BEDS OR BORDERS

Hyacinths-The grandest of all hardy flowering bulbs, delight millions of flower lovers throughout the world with their matchless beauty and rare fragrance.

Every home could be cheered in winter and every garden be glorified in spring with their fragrant and beautiful wax-like flowers. Hyacinths are amendable to the most diverse treat. ment and bloom in splendid profusion in the winter or spring, as desired.

They may be grown in pots, glasses or the garden. The colors, shades and tints are wonderfully varied, from the purest white through blush, pink, rose, etc., to the deepest red, and from daintiest porcelain through yellow to orange and rosy apricot, etc.

Named varieties, marked " $\mathbf{X X}$ " and ' $\mathbf{X}$," produce the finest trusses of blooms, and should always be selected for specimens in pots or glasses. The cheaper grades are usually used for bedding, garden borders, or for forcing for winter cut flowers.

\section{Culture of Hyacinths}

OUTDOOR CULTURE. - The preferable season is October, November and December, but bulbs will give good results if planted somewhat later. Plant so that the tops of the bulbs will be from two to three inches below the surface and five to eight inches apart. In preparing the bed, see that it is well drained, so that the bulbs will not rot during our long wet winters. After flowering, if the beds are wanted for late spring planting take up the bulbs, tops and roots, and "heel in" in some corner of the garden until the bulbs mature, after which they should be spread out in an airy room to dry, and kept in a cool, dark place until time for replanting the following autumn.

CULTURE IN GLASSES.-When it is desired to grow Hyacinths or Narcissus in water, they should be placed so that the base of the bulb merely touches the water. The glass should then be set in a cool, dark place, until filled with roots, when they may be brought into the light. Fill the glasses with fresh water every few days. Give as much fresh air as possible without letting the plants stand in a draught, and as nearly as possible at a temperature of 60 degrees until the spikes are developed.

INDOOR CULTURE IN POTS.-Bulbs for winter blooming can be planted from September until December-the earlier the better. Plant one bulb to a four-inch, or three to a six-inch pot. Then place in a cool, dark cellar, watering well. The whole success of pot culture depends on getting the roots well established in the pots, at a low temperature of, say, 40 to 50 degrees, before you begin to force the tops. From four to six weeks is not too long to leave them in a dark, cool place.

After this the bloom is easily developed by giving light, keat and water, and one can have a supply of flowers from Christmas until Easter by regulating the time of bringing them to light.

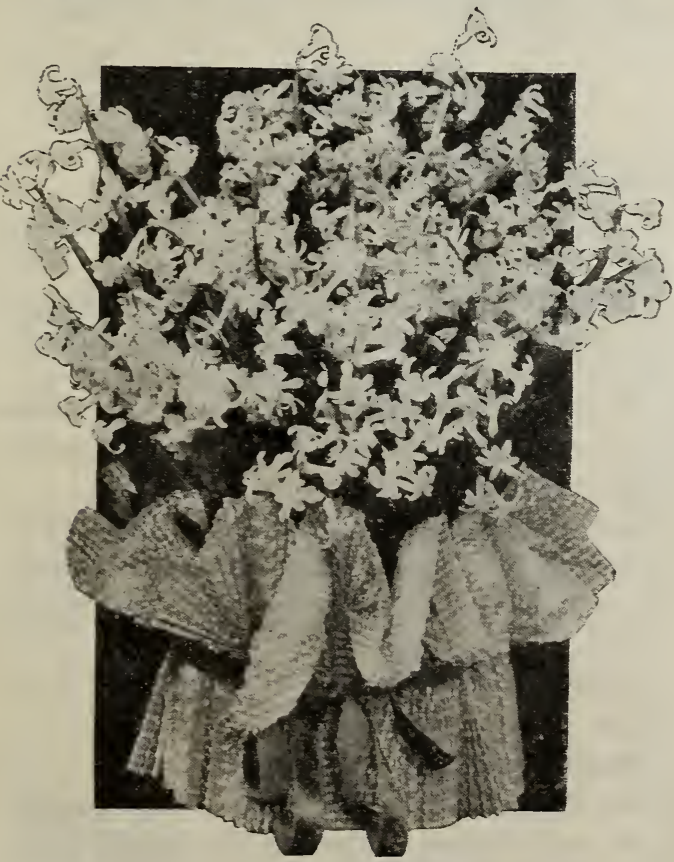

SELECTED FRENCH

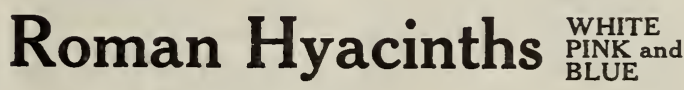

A charming class of Hyacinths, extensively grown by florists for winter flowering. Each produces several very graceful flower spikes. The delicious perfume, earliness and profusion of bloom have made Roman Hyacinths exceedingly popular. They are so easily grown and so early that if potted early they can be brought into flower in November and December, and a succession can be had in bloom throughout the winter and early spring.

The best effect is produced by planting four to twelve bulbs in the shallow bulb pots. They may also be planted outdoors.

For cutting purposes the Roman Hyacinth is the finest bulb grown and is most valuable for early planting in the house. Be sure to state whether you want White, Pink or Blu White "Romans" are the best bloomers.

First size, select julbs, $7 \mathrm{c}$; dozen, $75 \mathrm{c} ; 100$

Roman Hyacinths $\$ 5.00$ 


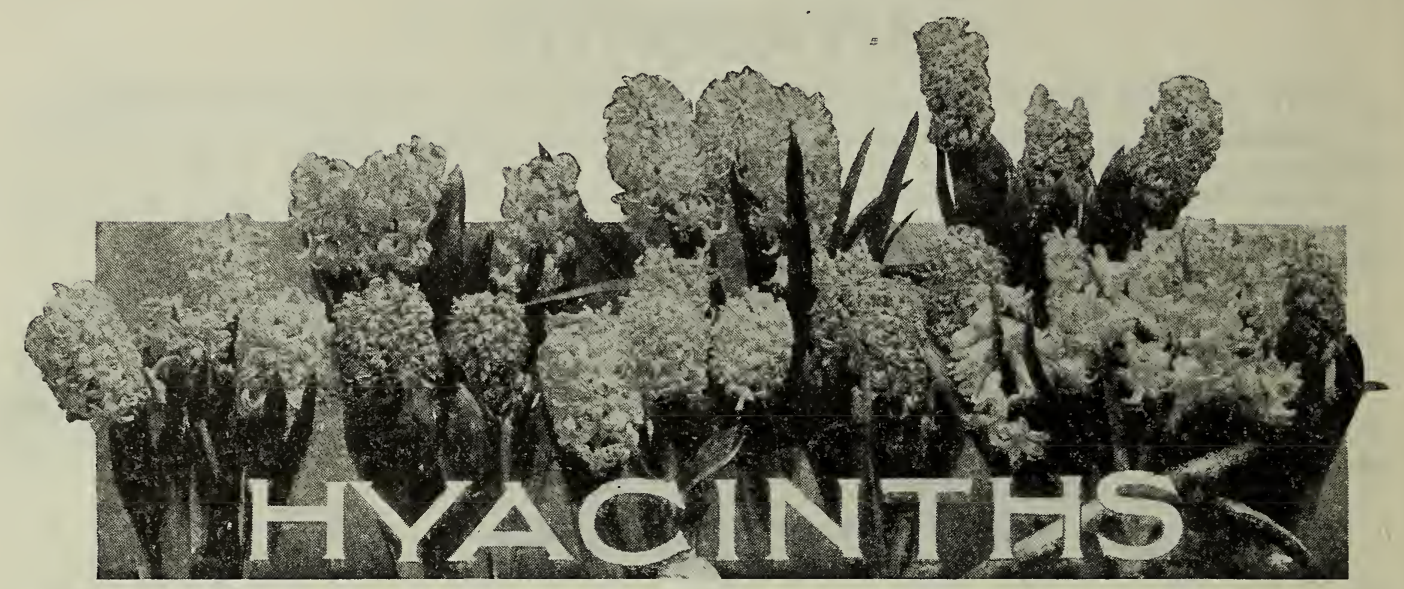

\section{“DIAMOND QUALITY" TOP ROOT BULBS---Select Single Named}

Our " $\mathrm{X}$ " Grade.-For those of our customers who want to produce Hyacinths of the grandest size and finest quality, we recommend our ' $\mathbf{X X}$ '" grade. These are extra choice, large, round, solid bulbs, selected especially for our best trade by our Holland growers. They will produce those handsome, mammoth flowers so highly prized, and are excellent for forcing and pot culture.

Our " $\mathrm{X}$ " Grade.-This grade is usually bought, and we sell more of this price and size bubs than any other. Our " $\mathrm{X}$ ', grade is equal, if not superior, to the "First", or "Select Grade', offered by many seed stores.

\section{Prices Postpaid}

XX Grade...Each...\$0.15 ; doz.... \$1.50 XGrade...Each... .121/2; doz... 1.25 Special prices by the hundred-State varieties preferred.

\section{Single Red and Pink.}

Baron Van Thuyll-Fine pink, large spikes, early; forces easily.

Cavaignac-I_arge Salmon Pink, forces well, a good keeper, extra fine for exhibition.

Charles Dickens-This is decidedly one of the finest pinks; spikes large; easy to force.

General Pelissier-Brilliant carmine, compact spike; an early forcer. One of the best.

Gertrude-Fine rosy pink; excellent sort for forcing or bedding. Flowers large.

Gigantea-Fine blush pink; giant, compact spike; a popular sort among gardeners.

King of Belgium-Fine deep scarlet; compact truss. Excellent bedder.

Lady Derby-(New)-Lovely light rose pink, large spike.

Moreno-Extra fine pink, very large spikes and bells; forces easily. Highly recommended.

Norma-Pale, waxy pink, handsome, large and good forcer. Extensively planted.

\section{Two New Beauties}

Queen of the Pinks-New, extra large spike of great beauty; color bright shell pink, dainty, gracefully formed florets. The finest Pink Hyacinth. Select bulbs.

Each, postpaid, 60c

La Victoire-New brilliant carmine. The most beautiful and distinctive of this color. Select bulbs.

Each, postpaid, 40c

Be sure to include "Queen of the Pinks", and "La Victoire"' in your order. You have never seen their equal.

\section{Single Blush White}

Grand Blanche-A fine blush white, flowers large and of excellent quality.

Grandeur a Merveille.-Lovely blush white, the best of its color; very large spikes. Very popular.

Mr. Plimsoll-Extra fine, blush white, large flower and bells.

\section{Single Pure White}

Arentine Arendse-Grand pure waxy white flower, with large spike and bells.

Blancheur d'Merveille-Pure white, large, good form, extra fine.

British Queen.-Pure white, very fine for early forcing, large compact spikes, very desirable.

Baroness Van Thuill. - Large, pure white. handsome, compact spikes, very early, grows well in glasses.

La Grandesse.-Extra fine snow white, large spikes of fine formed bells, a grand exhibition variety, having no equal among the single whites.

L'Innocence.-One of the earliest; pure white; fine for forcing.

Madam van der Hoop.-Pure white. We believe this is the best white for general planting; flowers large and handsome; erect habit; very popular. 


\section{SELECT SINGLE NAMED HYACINTHS-Continued Single Blue}

Grand Lilas-Extra fine porcelain blue, grand large spikes and bells; forces easily. The finest light blue.

Johan-Fine light blue, extra large, splendid bedder.

King of Blues-Deep glossy blue, large compact spikes. The finest dark blue Hyacinth in cultivation.

La Peyrouse-Dainty porcelain blue; grand size; best of the pale blues for bedding.

Enchantress-Clear pale blue; one of the finest exhibition rarieties.
Lord Derby-Pearl blue, very large hand some spike, good for glass, very desirable sort.

Marie-Dark violet blue, immense spikes of good form, comes early, grows well in glass

Grand Maitre-Deep porcelain blue; spikes large and handsome. ding.

Regulus-A lovely clear blue, fine for bed

Queen of the Blues-A beautiful light blue with silvery sheen; a large, handsome flower, a farorite with florists.

\section{Single Yellow}

Ball of Gold-Large compact spike, golden yellow, best of its color.

Ida-Best pure yellow, for early forcing, fine large spike.

King of Yellows-Fine, bright golden yel-

low, grand spikes, a superior bedding variety. MacMihon-Rich yellow, large spike. Ex cellent flower, forces early.

Yellow Hammer-Golden yellow, extra fine flower, forces easily; exhibition variety.

\section{Select Double Named Hyacinths}

\section{All are First Size, Iarge, Solid, Select Bulbs}

Price, each 15c; dozen, $\$ 1.50$

While the flowers of Double Hyacinths are large and beautiful, the spikes are not generally so full of bells as those of the single sorts.

\section{Double Red}

Bouquet Royal-Salmon pink, red center; very choice.

Noble par merite-Deep red, fine large spike; early; fine forcer.

Lohengrin-Fine bright pink.

\section{Double Blue}

Bloksberg-Light blue, marbled.

Charles Dickens-Dark porcelain blue, extra fine spike and bells.

Garrick-Deep azure blue, very large spike.

\section{Double White}

Bouquet Royal-Pure white, large spike, very fine.

La Tour d'Auvergne-Earliest pure white; a grand flower.

Isabella-Fine blush white; grand spike; excellent.

\section{Double Yellow}

Goethe-Light yellow, large spike, one of the best double yellow Hyacinths.

William III-Rich orange yellow, good bloomer, one of the very best yellows.

\section{"DIAAMOND, Bedding Hyacinths}

\section{Assorted Colors}

A superior grade of large size, selected bulbs, generally used for planting outdoors in making up beds, borders or large displays, but are equally good for forcing. . They are low in price but of superior quality and will all produce fine spikes of bloom. These Hyacinths are not to be classed with the cheap grade of bulbs usually sold as "mixed" Hyacinths.

\section{Single}

\begin{tabular}{|c|c|c|c|c|}
\hline & Each. & Doz. & & Each. \\
\hline$e^{k}$ & $\begin{array}{l}. .90 .06 \\
\ldots \quad .06\end{array}$ & $\begin{array}{r}\$ 0.65 \\
.65\end{array}$ & $\begin{array}{l}\text { Blush White } \\
\text { Light Blue }\end{array}$ & $\begin{array}{l}. \$ 0.06 \\
. \quad .06\end{array}$ \\
\hline hite & .06 & .65 & Dark Blue & .06 \\
\hline e Why & .06 & .65 & Yellow .. & .06 \\
\hline
\end{tabular}

Per 100

\section{Double}

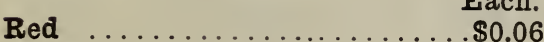

Doz.

White $\ldots \ldots \ldots \ldots \ldots \ldots \ldots . .06$

$\$ 0.65$

Light Blue .............\$0.06

Pink .................. .06

Pure White ............... $06 \quad .65$

Yellow $\ldots \ldots \ldots \ldots \ldots \ldots \ldots \ldots, .06$ 


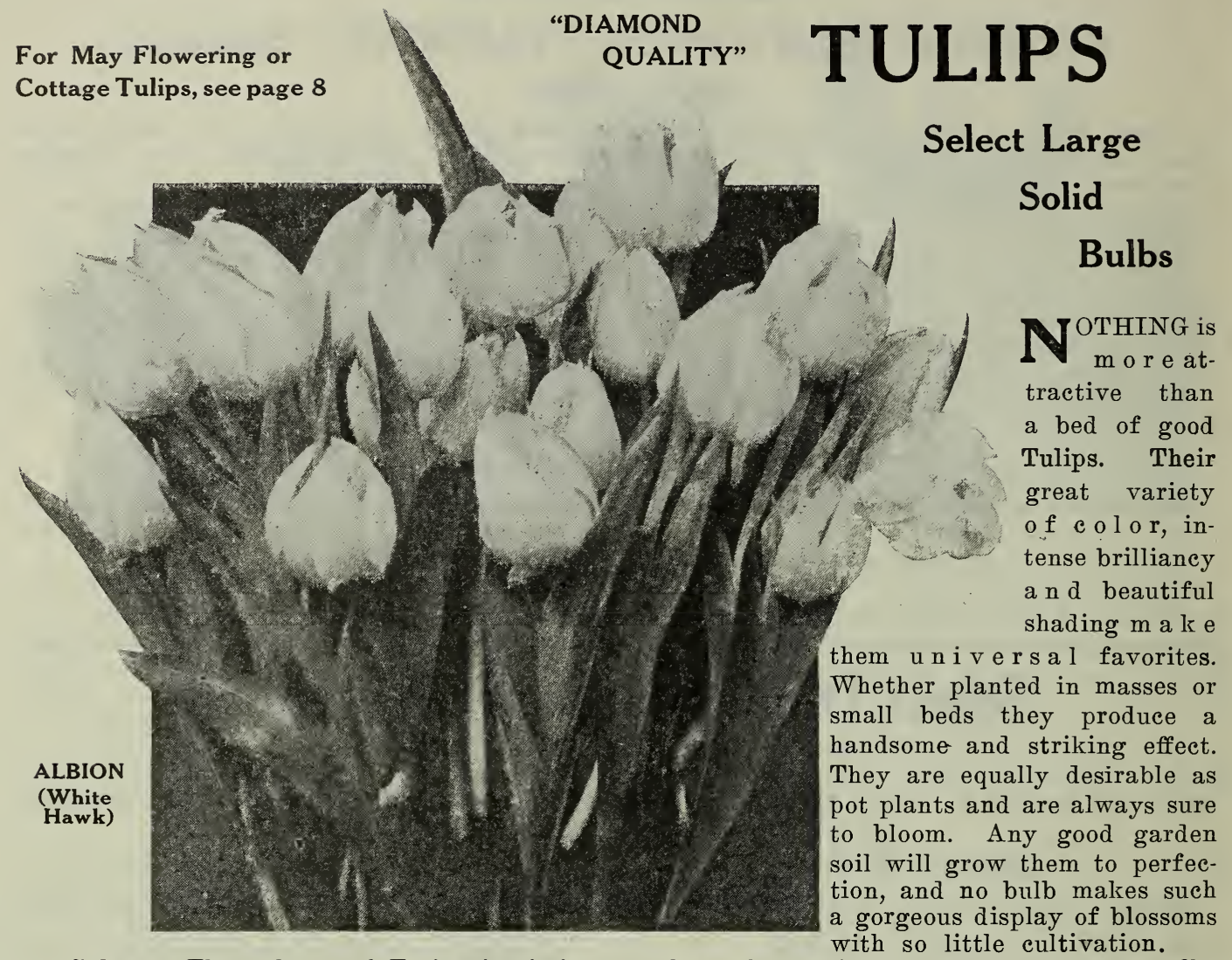

Culture-The culture of Tulips is similar to that of Hyacinths, except that the bulbs should not be planted quite so deep, and from three to six inches apart. All Single Tulips force easily. For indoor planting we have regular Tulip pans. Plant four bulbs to a sixinch pan; eight to an eight-inch pan, etc.

The letters A, B, C, following the varieties, indicate their earliness of bloom; the A's are the earliest, B's follow, etc. The average height in inches is also given for your benefit in selecting for bedding purposes.

Outdoors-Early or late planting does not seem to have much effect on Tulips, but they should be planted in fresh, rich soil, but not freshly manured, manuring should be done 6 months before planting.

\section{Single Early Tulips}

\section{Single Scarlet}

Artus, B 7-Deep, brilliant scarlet, fine for forcing or bedding.

Each, 3c; doz., 30c; 100, $\$ 1.50$

Belle Alliance, B 7-Brilliant scarlet, sweet scented, excellent for forcing and bedding.

Each, 5c; doz., 50c; $100, \$ 3.00$

Duc van Tholl, A 6-Bright scarlet; one of the finest for bedding and forcing.

Fach, 4c; doz., 40c; 100, $\$ 3.00$

Prince of Austria, B 12-Bright orange vermillion, large sweet-scented flower, fine forcer and bedder.

Sach, 4c; doz., 40c; 100, $\$ 3.00$

Vermillion Brilliant, B 8-A beautiful flower; forces easily and early; one of the largest and finest scarlets.

Each, 8c; doz., 50c; $100, \$ 4.00$

\section{Single Violet}

Wouverman, B 8-Purple violet, large flowers; fine for outdoor planting.

Each, 6c; doz., 60c; 100, $\$ 5.00$
Cramoise Brilliant, B 10 (Sparkler) Bright vermilion, large flowers of great substance, fine forcer:

Each, 4c; doz., 40c; $100, \$ 3.00$

Crimson King, B 7-Bright crimson or scarlet, easily forced.

Each, 3c; doz., 30c; 100, $\$ 1.75$

Maes, A 10-Rich scarlet tinged purple inside, center bronze with bright yellow ring; one of the earliest and best bedders.

Each, 5c; doz., 50c; 100, $\$ 4.00$

Pottebakker, A 8-Bright scarlet; large fine flower, good for forcing or bedding.

Each, 4c; doz., 40c; 100, $\$ 3.00$

Couleur Cardinal B 10-Rich bronze scarlet, large fine flower of great substance, long stems, erect habit; a splendid bedder and one of the best for forcing. Our stock is extra fine.

Each, 4c; doz., 40c; 100, $\$ 2.40$

Van der Neer, A 10-Large violet purple, fine form, early.

Each, 6c; doz., 60c; $100, \$ 5.00$

President Lincoln, B 8-Pretty shade of lilac violet. Each, 5c; doz., 50c; 100, \$3.75 


\section{EARLY SINGLE TULIPS---Continued \\ Single White}

Albion, B 10 (White Hawk)-One of the finest pure white Tulips in cultivation for forcing and bedding; flowers snow white, very large and of great substance.

Each, 5c; doz., 40c; 100, \$2.75

Duc van Tholl, A 7-Pure white; the best white Tulip for early forcing.

Each, 3c; doz., 30c; 100, $\$ 2.00$

Joost Van Vondel-White-B 9-Finest and most handsome pure white Tulip, extra large.

Each, 5c; doz., 50c; 100, $\$ 1.00$

Pottebakker, A 9-Pure white; fine large flowers.

Each, 4c; doz., 35c; 100, $\$ 2.50$

\section{Single Yellow}

Chrysolora, A 9-Pure golden yellow, large and fine; excellent for bedding.

Each, 3c; doz., 30c; 100, $\$ 1.75$

Gold Finch, B 9-Golden yellow, sweet scented; forces easily and early; stands well, a good bedding sort.

Each, 3c; doz., 30c; 100, $\$ 2.00$

Mon Tresor-A 10-Earliest golden yellow, fine large flowers, one of the best forcing $\mathrm{Tu}$ lips.

Each, 4c; doz., 40c; $100, \$ 2.50$

Thomas Morus, A 12-Apricot orange. The finest forcing tulip of its color, large elegant form, rery early.

Each, 3c; doz., 30c; 100, $\$ 2.00$

Primrose Queen, B $10-A$ beautiful new tulip; rich sulphur yellow; a splendid forcer and good keeper. Florists should try this.

Each, 6c; doz., 60c; 100, $\$ 4.00$

Golden Queen, A 13-A fine deep yellow, early and extra large.

Each, 5c; doz., 40c; 100, $\$ 3.00$

Yellow Prince, B 9-Sweet scented; one of the very best for forcing; a fine yellow.

Each, 3c; doz., 35c; 100, $\$ 1.75$
L'Immaculee, B 9-Pure white; good for forcing and bedding.

Each, 3c; doz., 30c; 100, $\$ 1.75$

La Reine, B 8-Pure white; best white Tulip for forcing and bedding.

Each, 3c; doz., 30c; 100, \$1.75

Princess Marianne, B 9-A large white sort, slightly tinged with pink; excellent for bedding.

Each, 3c; doz., 30c; 100, $\$ 2.00$

White Swan, C 14-A lovely egg-shaped pure white flower on long stems; extra fine cut flower. Each, 3c; doz., 30c; 100, \$2.00

\section{Single Pink}

Rose Grisdelin, B 7-Beautiful, delicate pink; finest pink Tulip in cultivation.

Each, 3c; doz., 30c; 100, $\$ 2.00$

Rachel Ruisch-A light shade of pink, fine for sutdoor planting.

Each, 3c; doz., 30c; 100, $\$ 2.00$

Rosamundi Huyckman, B 10- White, tipped and suffused rose.

Each, 3c; doz., 30c; 100, $\$ 2.00$

Rose Luisante, B 9-Deep pink, extra fine bedder; forces well.

Each, 4c; doz., 40c; 100, $\$ 3.00$

Queen of the Netherlands, A 13-Large, light pink, fine globe-shaped flower.

Each, 5c; doz., 50c; 100, $\$ 1.00$

Pink Beauty, B 11-Bright rose pink shading to blush, near yellow center. Has no equal in its class.

Each, 5c; doz., 50c; 100, $\$ 1.00$

Proserpine, A 12 -Fine glossy carmine pink, large and early forcer and a splendid bedding tulip.

Each, 5c; doz., 50c; 100, $\$ 1.00$ Finest Single Mixed This mixture contains all colors and shades, and is very fine for
bedding.
Each, 3c; doz., 25c; 100, $\$ 1.50$

\section{Single Variegated Tulips}

Brutus-Orange crimson, yellow edge; fine for forcing. Each, 3c; doz., 30c; 100, $\$ 2.00$

Cottage Maid, B 9-White bordered with, pink, extra fine and showy.

Each, 3c; doz., 30c; 100, \$1.75

Joost van Vondel, B 9-Deep, glossy, cherry red and white, large and attractive.

Each, 4c; doz., 35c; 100, $\$ 2.75$
Duchesse de Parma, $\approx$ 10-Terra Cotta with yellow edge, large flower, forces well, fine for beds.

Each, 3c; doz., 30c; 100, $\$ 2.00$

Keizerskroon, B 9-Bright red, with yellow edge; very large, no other Tulip makes such a handsome bed. Each, 4c; doz., 35s; 100, \$2.25

Standard Royal, B 9-Silvery white, feathered with cherry crimson.

Each, 4c; doz., 40c; 100, $\$ 3.00$

\section{Parrot Tulips ( $\left.\begin{array}{c}\text { For the } \\ \text { Ground only.) }\end{array}\right)$}

These Tulips have immense, attractive flowers of singularly picturesque forms and brilliant and varied colors. The petals are curiously fringed or cut. They form extravagantly showy flowers of endless variety of form and color, and should be grown in every flower garden.

Admiral de Constantinople-Orange red, good size.

Cafe Brun-Orange, red feathered; very showy.

Cramoise Brilliant-Beautiful carmine red, large flowers; very fine.

Lutea Major-Golden yellow, extra fine and large flowers.

Markgraaf-Inside rich orange, outside scarlet and yellow, feathered, extra fine.

Perfecta-Yellow, scarlet feathered.

Named Varieties.

Each, 3c; doz., 30c; 100, $\$ 2.00$

Fine Mixed-This mixture contains a large assortment of colors.

Each 3c; doz., 30c; 100, $\$ 1.50$ 


\section{Single May Flowering Tulips}

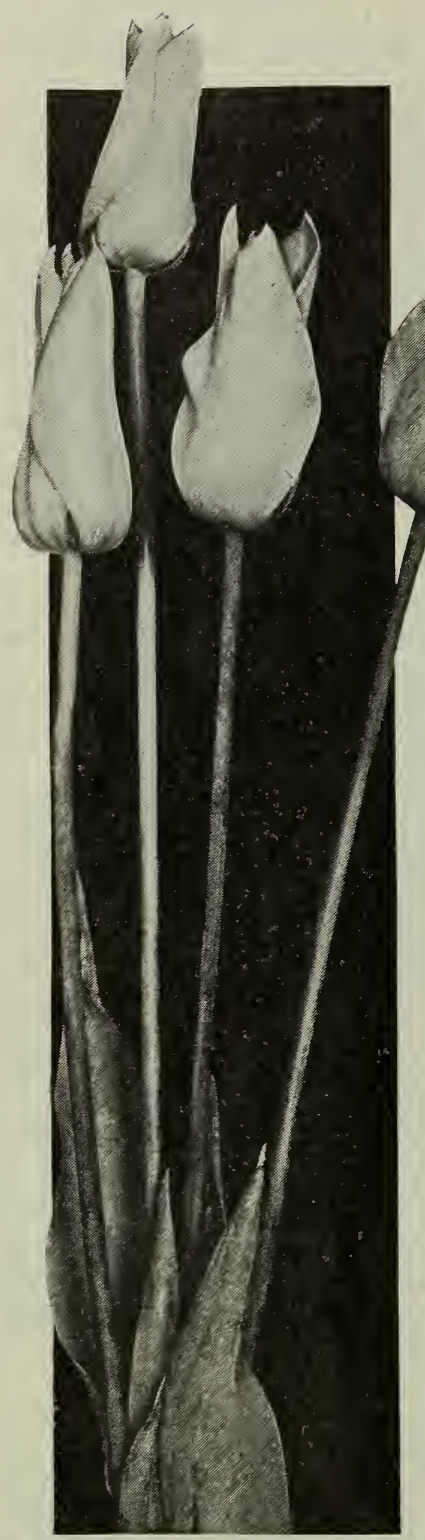

ELLEN WILLMOT

7 HESE are to be grown in the open ground only, each individual blossom being a marvel of beauty in itself. They grow from 18 to 24 inches high and appear at their best when used in the border, the foreground of shrubbery or buildings, or out of the way corners of the garden, where, if left undisturbed, they will bloom with increasing beauty for years. They are extremely hardy and the flowers norne on long, strong stems are good keepers when cut.

Bizarres-Yellow ground, flaked with crimson, purple and violet. Each, 3c; doz., 30c; 100, $\$ 2.00$

Bouton d'Or-Golden yellow, graceful form, beautiful flower. The only late pure deep yellow, Each, 3c; doz., 30c; 100, $\$ 1.50$

Byblooms-White ground, flaked with violet, crimson and maroon. Each, 3c; doz., 30c; 100, $\$ 2.00$ Gesneriana Iutea-Deep yellow, fine, large flower.

Each, 4c; doz., 35c; 100, $\$ 2.50$

Gesneriana Spathulata-Blooms large; color rich crimson with dark center.

Each, 3c; L.oz., 30c; 100, $\$ 2.00$ showy.

Golden Crown-Deep yellow, with crimson edge; very large.

Isabella-(Shandon Bells)-Cream turning to carmine,

Picotee-White with a pink border; fine for cutting.

Each, 3c; doz., 30c; 100, $\$ 2.00$

\section{Splendid Tulips for Rock Gardens}

Greigi-The Queen of Tulips,' handsome and distinct; flowers very large; brilliant orange scarlet with yellow and black center; spotted foliage.

Eàch, 12c; doz., $\$ 1.25 ; 100, \$ 10.00$

Kaufmanii-A wonderful new tulip blooming four weeks earlier than any other variety; color white inside, pink outside of petals; a rare and beautiful combination; a novelty of great merit. Each, 15c; doz., $\$ 1.50 ; 100, \$ 12.00$

Tubergiana-Giant of all Tulips; color brilliant vermillion with dark blotch at base; flowers 8 to 10 inches in diameter, height 20 inches, May flowering, prefers sunny situation, fine for rock garden.

\section{"DIAMOND" COLLECTION \\ 12 Most Beautiful Show Tulips}

Inglescombe Pink-Salmon pink with blue base; one of the finest of the large May flowering Tulips.

Each, 4c; doz., 40c; 100, $\$ 3.00$

Inglescombe Scarlet-Same form as above. Color a rich scarlet; black base. Each, 4c; doz., 40c; 100, $\$ 3.00$

Inglescombe Yellow-A large fine yellow of perfect form; may be used for yellow Darwin.

Each, 15c; doz., \$1.50; 100, $\$ 12.00$

The Fawn-Large oval flower, color light gray, changing to soft rosy white. Each, 7c; doz., 75c; 100, $\$ 6.00$

Caledonia-Bright orange vermillion; extra fine. Each, 4c; doz., 35c; 100, \$2.75

Elegans Red-Beautiful dark crimson; elegantly formed. petals reflexed.

Each, 5c; doz., 50c; $100, \$ 4.00$

Elegans Alba-White with red penciling on margin, gracefully reflexed petals, yellow anthers.

Each, 5c; doz., 50c; 100, $\$ 4.00$

Primrose Beauty-Soft primrose, changing to white; a magnificent flower of the Willmot type.
Vitellina-Pale primrose, passing to pure white; a graceful, artistic flower slightly reflexed. $\quad$ Each, 5c; doz., 50c; 100, \$3.75

Fairy Queen-Rosy heliotrope, broadly margined yellow; inside of petals brownish red. Each, 5c; doz., 50c; 100, $\$ 3.50$

Mrs. Moon-Large orange yellow. A superb Tulip, the best of its color.

Each, 7c; doz., 75c; 100, $\$ 6.00$

Ellen Willmot-An exquisite shade of rich creamy yellow; large, refined flower; delicious fragrance; long keeper. The finest May flowering Tulip. Each, 10c; doz., $\$ 1.00 ; 100 \$ 8.00$

NSPECIAI_For trial, nne each of these 12 beautiful rare Tulips for only 70c, postpaid. 


\section{New Giant Darwin Tulips}

This new class of giant May flowering Tulips have a majestic beauty distinctively their own that is invaluable for garden and landscape effects, while their immense globular flowers of perfect form and satiny, waxlike texture, long stems and lasting qualities, make them ideal for cutting. They come in the most varied and brilliant coloring, from white through dainty pinks, salmon, rose, and deep rich reds to black, lavenders, heliotrope, blue, violet, purple, bronzes and browns, but as yet no pure yellow. Inglescombe Yellow, page -8 , in the May flowering Tulips can be used and is known as the Yellow Darwin.

For best effects Darwins should be planted in clumps of from 15 to 25 bulbs of one color, or in the foreground of shrubs, trees, borders, or buildings. They prefer partial shade, but will thrive in any location. They come in hundreds of varieties, of which we offer the following as the best of their color. Try them.

Bronze Queen-Extra large light bronze yellow. Each, 8c; doz., 85c; 100, $\$ 6.00$

Clara Butt-Deep apple blossom, extra fine. Each, 7c; doz., 70c; 100, $\$ 5.25$

Gretchen-Large globular delicate pink flower, inside soft blush.

Farmscombe Sanders-Beautiful fiery scarlet; best of its color.

Each, 8c; doz., 80c; 100, $\$ 5.00$

Kate Greenway-One of the largest and latest; immense white flowers suffused with lilac. Each, 5c; doz., 40c; 100, $\$ 3.00$

La Candeur - (White Queen) - Splendid white flower, tinged delicate blush; large size.

Each, 5c; doz., 50c; $100, \$ 4.00$

La Tulipe Noire-The Black Tulip, flowers large, lustrous and attractive, of fine form, true Darwin type, grows 24 inches high, May flowering. A rare novelty.

Each, 30c; doz., $\$ 3.00$

ASSORTED NAMED VARIETIES.

Loveliness-A beautiful soft rosy carmine; extra fine. Each, 4c; doz., 40c; 100, $\$ 3.00$

Mme. Krelage-Bright pink, lighter edge. Each, 5c; doz., 50c; 100, $\$ 3.50$

Pride of Haarlem-Brilliant salmon rose, shaded scarlet, blue at base; of grand size and form. Each 5c; doz., 50c; 100, $\$ 4.00$

Rev. Ewbank-Soft Maure, light edging. Each, 5c; doz., 50c; 100, $\$ 4.50$

The Sultan-Glossy blackish maroon.

Each, 5c; doz., 50c; 100, $\$ 4.00$

Mrs. Cleveland-Lovely delicate pink of finest form. Each, 5c; doz., 50c; 100, $\$ 4.00$

William Copeland-A fine large flower, bright rosy lilac. White base, blue zone.

Each, 5c; doz., 50c; 100, \$3.50

Yellow Perfection-Golden yellow, orerlaid purplish bronze and brown.

Each, 5c; doz., 50c; 100, \$3.50 MIXED. Each, 4c; doz., 40c; 100, $\$ 3.00$

\section{Early Double Tulips}

7 HE double Tulips are used mostly for outdoor planting and bloom a little later than the early Single Tulips. Being double and full, the blooms last longer. This, with the great variety of colors, shades and markings, makes them favorites with many.

Couronne d'Or, B 8-Fine yellow, the best double yellow for forcing, strong stem and stands handling well.

Each, 5c; doz., 40c; 100, $\$ 2.75$

Duke of York, B 10-A lovely carmine having a white edge; very showy; fine for bedding. Each, 4c; doz., 35c; 100, \$2.25

Gloria Solis, A 9-Deep crimson, with a broad, golden yellow margin; a grand flower.

Each, 4c; doz., 40c; 100, $\$ 3.00$

Ia Candeur, B 8-Pure white, very full and double; extensively grown in open beds.

Each, 4c; doz., 35c; 100, $\$ 2.25$

Murillo, B 8-This is decidedly the best double pink Tulip for forcing or bedding; flowers large and full; very fine.

Each, 3c; doz., 30c; 100, $\$ 2.00$

Queen Victoria, B 8-Carmine, a lovely flower; good bedder.

Each, 3c; doz., 30c; 100, $\$ 2.25$

Rubra Maxima, B 9-Bright crimson, scarlet, superb variety for bedding; cannot be forced; flowers large.

Each, 4c; doz., 40c; 100, $\$ 2.50$

Salvator Rosa, A 7-Beautiful deep rose, flamed with white; fine for forcing.

Each, 4c; doz., 40c; 100, $\$ 2.50$

Tournesoll, A 9-Bright red, with yellow edge, sweet scented, large flower. One of the easiest doubles to force.

Each, 5c; doz., 50c; 100, $\$ 3.50$

Early Double Mixed-This mixture contains a large and choice assortment of all colors and shades; very suitable for outdoor planting.

\section{Late Double Tulips}

These are handsome and showy, and are often planted in small groups about the yard, as well as in large beds. Following varieties grow quite tall.

Blue Flag-Bluish violet, one of the best dark shades.

Each, 5c; doz., 50c; 100, $\$ 3.50$

Marriage de $\mathrm{ma}$ fille-White, feathered with cherry crimson, flowers large. full and double; very showy.

Each, 5c; doz., 50c; 100, $\$ 3.50$

Yellow Rose-A handsome golden yellow; a good bloomer. Each, 4c; doz., 35c; $100, \$ 2.00$ 


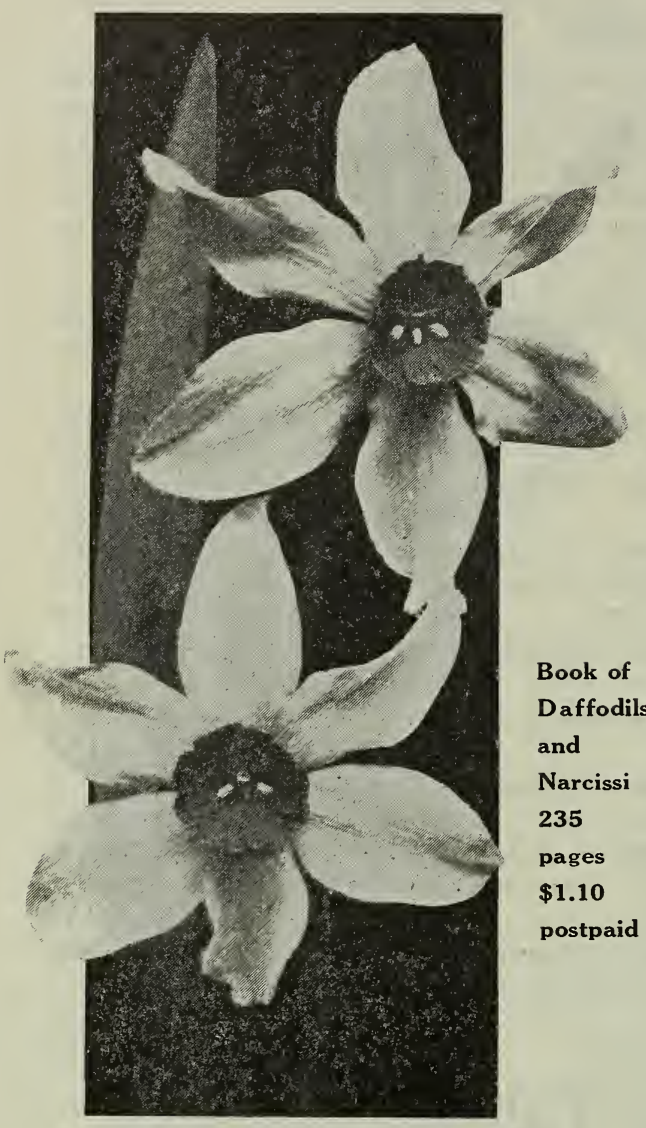

\section{PORTLAND SEED COMPANY'S

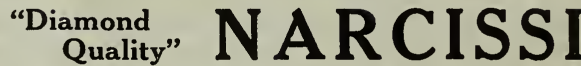

We consider Narcissi to be the most satisfactory and valuable of all flowering bulbs; coming in endless variety, adapting themselves to every planting condition or requirement, their stately and delicate beauty, exquisite perfume, earliness, free blooming and keeping qualities, endear them to all who have grown them.

Once planted in the field or garden they need no further attention but will thrive and perpetuate themselves, increasing in beauty for years.

\section{Popular Types}

The Polyanthus, flowering in clusters; the "Paper White" being the earliest, easiest to force and best known of this class.

The Trumpet types or "Daffodils", are the most widely known, and some of the best garden varieties are of this class; they also force easily, making ideal pot plants.

The "Chalice Cupped" or Star Narcissus are the daintiest and most charming of all types. To this class belong the Incomparabilis, Barrii, Leedsii, etc., .. all splendid garden varieties that will also give perfect results when grown in pots or forced.

The white flowered Poeticus type 'or "Pheasants Eye", Narcissus, give us some of the best of the later garden types, being hardy, sweet scented, very chaste and beau. tiful. Some varieties force easily, others are best suited to the garden or field.

The new Poetaz Narcissi are hybrids of Poeticus and Polyanthus types, forming a distinct and beautiful, free blooming, large flowered class that is attracting much attention and will be grown extensively as they become better known. They retain the polyanthus or cluster form of blooming, but the individual flowers are almost as large as the Poeticus types, equally valuable for bedding or forcing; extremely hardy.

Outdoor Culture-Plant in early fall if possible but plantings as late as Christmas will give excellent results. The depth to. plant is $1 \frac{1 / 2}{2}$ the depth of the bulb. This gives a covering of 2 to 3 inches of soil. Any good garden soil which has not been recently manured will give satisfactory flowers, but a deep moist loam is best. If the ground is dry or sandy it should be dug deeply, well manured and an annual, such as potatoes, grown the year previous. If your soil is light and you do not want to take annual, such as potatoes, grown the year previous. If your soil is light and you do not want a crop before planting, give a light dressing of lime to the surface and work in a layer of well rotted manure a foot below, so as to be out of reach of the bulbs, this layer is to hold the moisture, not as a fertilizer. The best fertilizer is ground bone. This can be used with safety on poor sandy soil. A little sulphate of potash, $3-4 \mathrm{oz}$. to the square yard, will improve the color of the flower and retain the moisture.

Pot Culture-The Bulbs should be planted as soon as received as earliest plantings insure finest flowers. In potting use good, turfy loam, but let no manure of any kind, well rotted or otherwise. touch the bulb. Set in a cool, dark room for a month or two, until well rooted, then remove to the light for flowering. (All bulbs prefer a cool temperature. Be careful not to grow them too warm). Do not cultivate too much, as extra vigor of growth injures the purity of color. Some Narcissi prefer partial shade but grow splendidly in any situation.

In Planting Narcissi large groupings of irregular outline give most pleasing effects, shun symmetrical lines or formal designs.

\section{New Cluster-Flower-Poetaz Narcissi}

These are hardy hybrids between Polyanthus and Poeticus, very vigorous, growth tall and stately, with clusters of delightfully fragrant flowers. They thrive and bloom in great profusion; good keepers, forcing or bedding.

FIVIRA-Long graceful stem, flower heads have three to four large blooms, broad, white petals, deep golden cup, with scarlet edge, delicious fragrance. IRENE-Deep cup, beautifully fluted, perianth sulphur yellow, superb.

Fach, 8c; doz., 75c; 100, $\$ 5.50$
Klondyke-Perianth yellow, cup deep golden yellow; one of the finest and deepest of the yellows.

Fach, 8c; doz., 75c; $100, \$ 5.50$

Ideal-White-Perianth dark orange cup, large truss, free bloomer.

Each, 8c; doz., 75c; $100, \$ 5.50$ 


\section{Narcissi-Polyanthus}

The Polyanthus varieties of Narcissi are not only beautiful, but deliciously sweet-scented, and of the easiest culture, very free flowering and suitable for foreing indoors or berding out, continuing long is bloom. They bear tall spikes of bloom, bearing from six to twenty-four flowers each.

\section{PAPER WHITE GRANDIFLORA}

Flowers pure white, especially desirable for their beauty and delicious odor. It forces admirably and flowers freely in dense clusters; will come into bloom as early as December, if potted early. Forced by florists for cut flowers. Anyone can grow them in the house successfully. Plant one bulb to a three-inch pot, four to a six-inch pot. Can be grown in water. See page 2 .

Each, 5c; doz. 40c; 130, \$2.0J

Grand Monarque-Large, pure white, with lemon cup. One of the finest in this class.

Each, 6c; doz., 60c; 100, $\$ 1.00$

Grand Soleil d'Or-Rich yellow, with orange cup; fine for bedding and cutting.

Each, 6c; doz., 60c; 100, $\$ 1.00$

The Pearl-Pure white flowers of mammoth size and very fine; looks very much like the Grandiflora, but is much larger.

Each, 6c; doz., 60c; 100, $\$ 1.00$

Extra Fine Mixed-A mixture of ten named varieties.

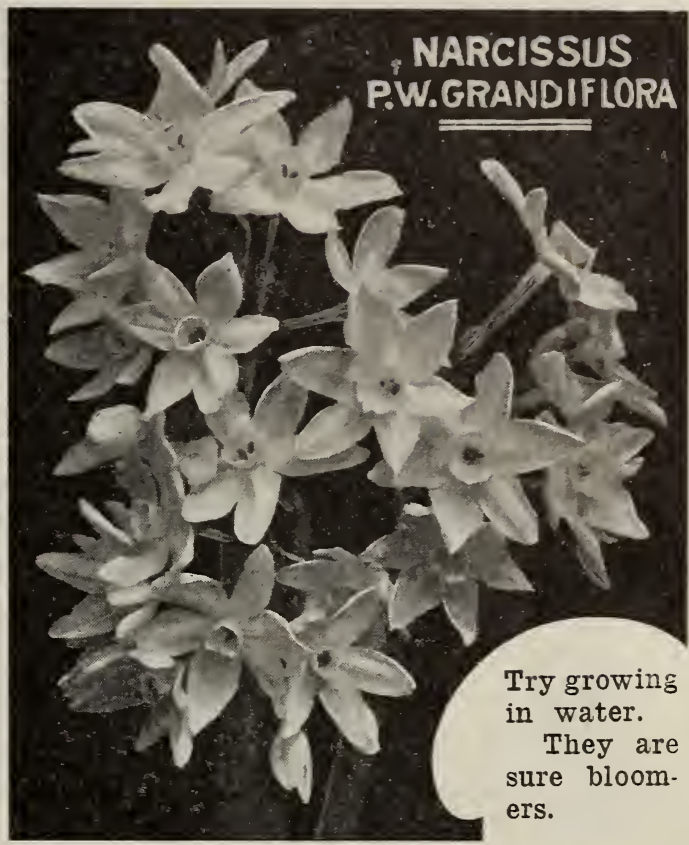

\section{Sacred Chinese Lily}

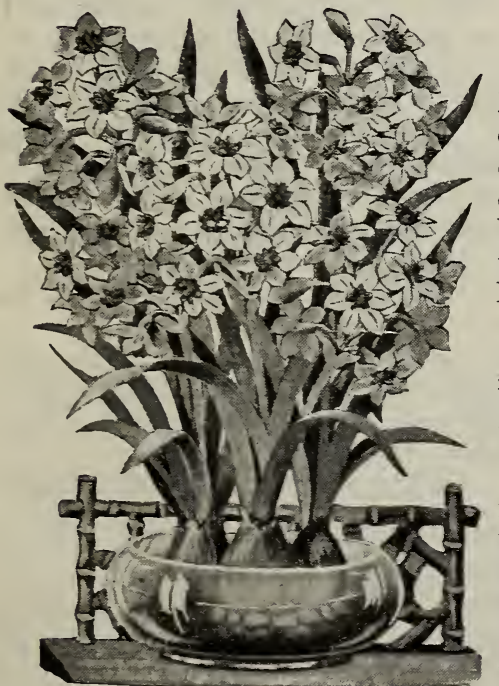

Cininese Sacred Lily

(Narcissus Orientalis.)

The "Shui Sin Far," or Water Fairy Flower, Joss Flower, or Flower of the Gods, etc., so called by the Celestials, is a variety of Narcissus, bearing in lavish profusion chaste flowers of silvery white, with golden cups, which are of exquisite beauty and entrancing perfume. They are grown by the Chinese, according to their ancient custom, to herald the advent of their new year and as a symbol of "good luck."'

By method of culture original to them, they succeed in growing large, solid bulbs, which produce a profusion of bloom in an incredibly short time, usually not more than four to six weeks from the time of planting.

These Sacred Lilies do well in pots of earth, but are more norel and beautiful grown in shallow bowls of water, with enough pebbles to prevent them from tipping uver when in bloom. A dozen bulbs started at intervals will give a succession of flowers throughout the winter.

This splendid flowering bulb increases in popularity each year, and we import annually, direct from China, immense quantities of the best bulbs.

The Chinese Lily bulbs offered by us are large, solid and well matured. They can be relied upon to be the true Chinese, which are superior to those grown in this country. Bulbs ready from September to April.

Each, $15 \mathrm{c} ; 2$ for $25 \mathrm{c}$; doz., $\$ 1.40$.

\section{LAWN FERTILIZER}

Fifty pounds of our Odorless Lawn Fertilizer, No. 5, scattered over a city lot will give the lawn a beautiful green, velvety appearance. Our Fertilizer Booklet tells all about our Diamond Fertilizers-for every purpose-gives valuable reference tables and practical information. It's Free, send for a copy. 


\section{DAFFODILS}

The trumpet types of Narcissi are the true old fashioned form of Daffodils, but we now have many new and wonderful sorts, they are the largest and most glorious of all Narcissi and are perfectly hardy everywhere. Can also be grown in pots. See page 10 for culture. We $\epsilon$ specially advise you to try Mad. de Graaf and Glory of Ieiden.

To enable you to plant for succession of bloom, we have numbered the varieties in their relative earliness. No. 1, early March; No. 2, late March; No. 3, early April; No. 4, late April; No. 5, May.

\section{TWO GRAND NEW GIANT DAFEODIIS} THAT YOU SHOUID GROW.

Mad. de Graaff-(4) - A lovely white daffodil. Opens with soft primrose trumpet passing to white, of perfect form, giant size, vigorous and free blooming; forces well and for garden or naturalizing in grass has no superior: height 16 inches. First-class certificate, R. H. S. See front cover. Pach, 25c; doz., $\$ \mathbf{2 . 5 0}$ Glory of Ieiden (4)-A fitting companion for the above; a bold, giant daffodil, with golden yellow trumpet, perianth lighter, very erect, of fine form and good substance; free blooming, forces well, is a good keeper and very hardy in open ground; height 14 inches. First-class certificate, R. H. S.

Fach, 20c; doz, \$2.00

Mrs. Thompson (2)-Large pure white, with elegantly frilled trumpet. a handsome free blooming daffodil. Each, 7c; doz.,75c; 100, $\$ 5.00$

Albicans-(2) -The " White Spanish Daffodil"')-Cream white, with silvery white trumpet slightly flushed with primrose and elegantly recurved at brim.

Each, 5c; doz.. 50c; 100, $\$ 3.50$

Bicolor Empress-(3)-Perianth snow-white, trumpet rich yellow, serrated and flanged at the edges, large in outline and of rare beauty.

Each, 5c; doz., 50c; 100, $\$ 3.50$

Bicolor Victoria-(2)-A magnificent large variety, bold and erect. A rare beauty; sweetscented and the best of the bicolor varieties. Perianth white and of great substance; trumpet rich yellow.

Each, 5c; doz., 50c; 100, $\$ 3.50$

Mrs. Walter Ware-(3)-A bicolor of great size and beauty, broad white perianth, long yellow trumpet, frilled, a vigorous free bloomer, award of merit R. H. S.

Each, 7c; doz., 75c; 100, 5.00

Mme. Plemp-(4) - This splendid new bicolor has pure white perianth and golden yellow trumpet, extra large shapely flower; a little later than Mrs. Ware.

Each, 7c; doz., 75c; 100, $\$ 6.00$

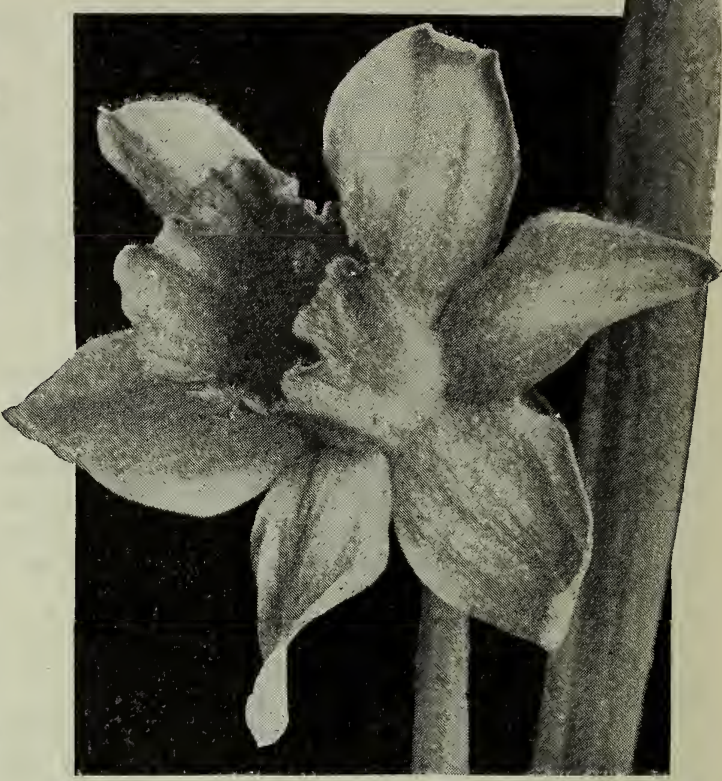

Emperor-(3)-A magnificent flower; perianth primrose; trumpet large, rich deep yellow. One of the finest Daffodils in cultiva-

Fach, 5c; doz., 50c; 100, $\$ 3.50$

Golden Spur-(1)-One of the grandest Daffodils, with extra large, bold, rich, golden yellow flowers, foliage very broad and striking; of robust habit and unsurpassed for gardens, pots and forcing.

Each, 5c; doz., 50c; 100, $\$ 3.50$

Princeps-(1)-A maguificent flower and one of the finest of the large trumpet type. As a forcing variety it is superior in every way; perianth pale sulphur; trumpet rich yellow. Each, 4c; doz., 35c; 100, $\$ 2.00$

Trumpet Major-(3)-Flower large and almost of a uniform deep golden; highly prized as an early forcing sort and largely planted for outside bedding. Fine for cutting.

Each, 4c; doz., 35c; $100, \$ 2.00$

Obvallaris - (1) - (Tenby Daffodil) - A beautiful and distinctive type. Perianth and trumpet rich, full yellow, large, of good substance and perfect form. Very early, ideal for naturalizing, flower well.

Each, 6c; doz., 60c; 100. $\$ 3.50$

\section{Jonquils - Native of Spain-A Species of Narcissus}

Very popular on account of their easy cultivation and very fragrant, golden yellow p1ooms, which remain a long time in perfection. Easily grown in the house or open garden. Half a dozen bulbs can be put in a five-inch pot, and with the same treatment as recommended for Hyacinths a fine display can be produced from January to April.

For garden display nothing is finer, they are lasting, flower freely, are deliciously perfumed, and of a beautiful golden yellow; best of all they are inexpensive and should be planted freely.

Jonquil Campernelle-Single-Large, yellow flowers, 4 to 6 borne on each stem, fine forcer, splendid garden sort, height 18 inches.

Each, 4c; doz., 35c; 100, \$1.75

Double Jonquil-Very double, deep golden
Jonquil Rugulosus-Improved giant Jonquil, broadly imbricated perianth wrinkled cup, beautiful rich yellow.

Fach, 3c; doz., 30c; 100, $\$ 2.00$ yellow, deliciously fragrant. 


\section{DOUBLE DAFFODILS}

Van Sion-(Telamonius Plenus) (2) — "The True Double Yellow Daffodil.", Rich golden yellow perianth and trumpet. This is the old favorite so highly prized and deserves to be planted in quantity where it can remain undisturbed for several years. It will then thrive and bloom in increasing profusion every spring and is also one of the best winter flowering and forcing sorts, immense quantities being used for this purpose.

Each, 5c; doz., 40c; 100, $\$ 2.50$

Van Sion-Double nose, extra large bulbs. Each, 6c; doz., 65c; $100, \$ 3.75$
Silver (Sulphur) Phoenix (3)-Very large flowers; pale creamy white, shading to primrose. One of the finest varieties for pot culture, and makes a splendid cut fiower.

Each, 5c; doz., 50c; 100, $\$ 3.00$

Alba Plena Odorata-(6) - "The Double White Poet's Narcissus.', Double, snowwhite flowers, exquisitely scented; late flowering; cannot be forced.

Each, 3c; doz., 30c; 100, $\$ 1.75$

Orange Phoenix (3)-(Eggs and Bacon)Beautiful double white flowers, with orange center; splendid for pot culture, cutting and garden planting. Each, 5c; doz., 40c; 100, $\$ 2.00$

\section{"Chalice Cupped" or Star Narcissi}

Incomparabilis, Barrii, and Leedsii, are types of this class of hardy, vigorous, free flow. ering Narcissi. They also force well, are inexpensive and most beautiful. Be sure to plant them.

Sir Watkin (2)_"The Giant Chalice Flower,", or "'Big Welshman.', A gigantic variety, having immense, long-stemmed flowers, sometimes measuring five inches across, and is the largest variety grown. Color a rich light yellow, with a large, dark cup, tinted with orange.

Each, 5c; doz., 50c; 100, $\$ 3.50$

Incomparabilis Simplex-Yellow, fine for forcing and cutting; flowers well formed and fragrant.

Each, 4c; doz., 35c; 100, $\$ 2.00$

\section{Barrii Types}

Barrii Conspicuus (4)-The finest of this class; lon broad-petaled perianth; sparkling canary yellow, with deep golden cup, richly edged with orange scarlet. First-class certificate, R.H.S.

Each, 4c; doz., 35c; 100, $\$ 1.50$

Flora Wilson-(4)-Pure white perianth, yellow cup, edged orange scarlet, a striking beauty. Each, 7c; doz., 75c; 100, \$6.50

\section{Leedsii Types}

Mrs. Langtry (4)-A remarkable, free flowering variety, with broad white perianth and large white cup edged yellow. Firstclass certificate, R. H. S.

Each, 4c; doz., 35c; 100, $\$ 2.00$

Beauty (4)-Sulphur yellow, large yellow cup, margined orange scarlet; a bold, handsome flower. Each, 7c; doz., 75c; 100, $\$ 5.50$
Minnie Hume (3)-Large white perianth, spreading cup, passing from lemon yellow to white. One of the best and most beautiful. Also awarded a first-class certificate, R. H. S.

Each, 4c; doz., 35c; 100, $\$ 2.00$

Duchess of Brabant (3)-Perianth white, yellow cup, vigorous and free blooming.

Each, 4c; doz., 35c; 100, $\$ 2.00$

M. M. de Graaff (4)-Long white perianth, orange rose cup, comes two flowers on a stem, fine. Each, 5c; doz., 50c; 100, $\$ 3.50$

Katherine spurrell (4)-Large shapely flower, sulphury white, perianth, canary cup. Each, 7c; doz., 75c; 100, $\$ 5.00$

Queen Bess (1)-Pure white perianth, bright yellow cup, large and very early.

Each, 5c; doz., 50c; 100, $\$ 3.50$

Frank Miles (3)-Large, soft, clear yellow; petals gracefully curred and twisted.

Each, 5c; doz., 50c; 100, $\$ 3.75$

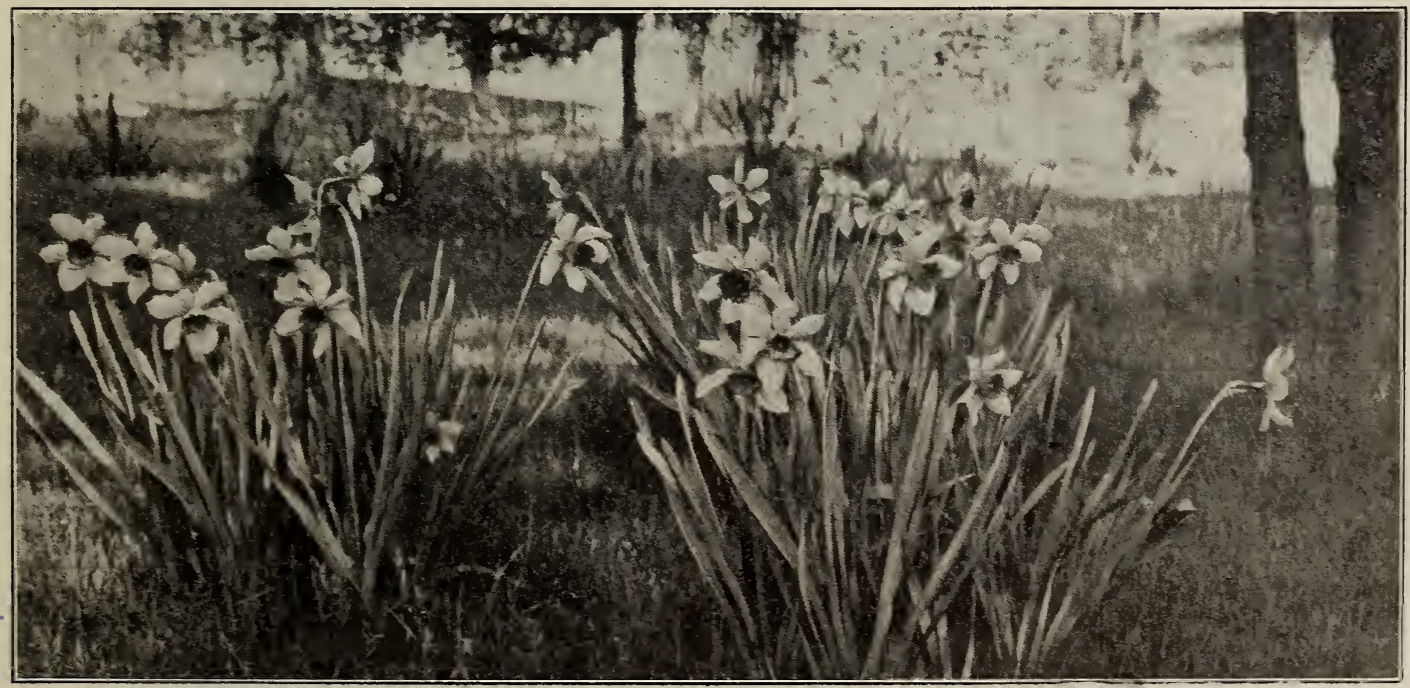




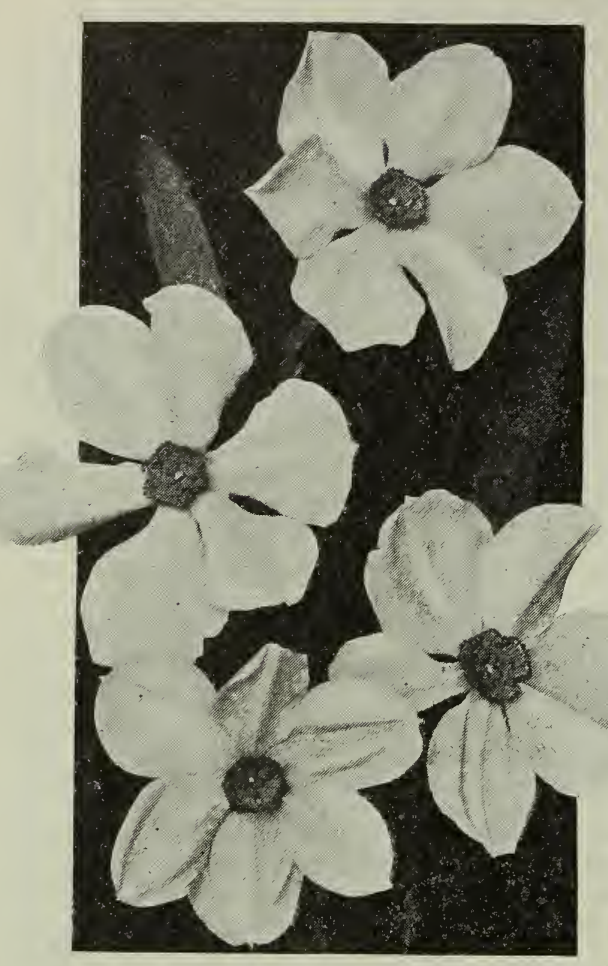

New "Poeticus Glory"

\section{NARCISSI-Continued \\ Poeticus Varieties}

Poeticus Varieties-These are among the among the most beautiful of all spring flowering bulbous plants. The large, single blossoms, 2 to $21 / 2$ inches across, are of a snowy whiteness, intensified by the exquisite golden-colored cups, ringed like a pheasant's eye, with red and green. The flowers are gracefully poised on long, stout stems, adapting them for vases. They are especially valuable for garden planting. If allowed to remain undisturbed, they thrive, spread and improve every year.

Glory (4)-The new Poeticus, largest of the type. Snowy white, perfectly tormed petals; a flower of great beauty, with every good quality.

F. C. C., R. H. S. Each, 20c; doz., $\$ 2.00$

Poeticus (Pheasant's Eye) (5)-(See cut)Pure white flowers, orange cup, edged with red. Very useful for cutting in spring, as they can be planted in borders out of doors, where they are perfectly hardy, and will bloom year after year. Does not force.

Each, 3c; doz., 30c; 100, $\$ 1.50$

Poeticus Ornatus (4)-(The Improved Poeticus)-Pure white cup, edged with scarlet, much finer in form and earlier than Poeticus. A mag. nificent cut flower. Largely used for forcing.

Each, 3c; doz., 30c; 100, $\$ 1.50$

\section{Miscellaneous Spring Flowering Bulbs}

\section{Snowdrops \\ GALANTHUS}

The first flower to bloom in the spring, producing small but beautiful white blossoms before other outdoor plants are started. Plant about one inch apart in borders, beds or in clumps in the lawn, setting two or three inches deep. They come up from year to year and need not be disturbed until they become crowded. (See cut.)

Snowdrop Elwesi-(Giant Snowdrop), single.

Two for 5c; doz., 25c; 100, $\$ 1.25$

Snowdrop-Double. Each, 3c; doz., 30c; 100, $\$ 2.00$

\section{Ixias}

The Ixia is a beautiful little flowering bulb, with low, slender, graceful spikes of bloom. The colors are rich, varied and beautiful. Culture same as Hyacinths. Named Varieties, Mixed. Each, 4c; doz., 40c; 100, $\$ 2.00$ Fine Mixed.

Each, 3c; doz., 25c; 100, \$1.25

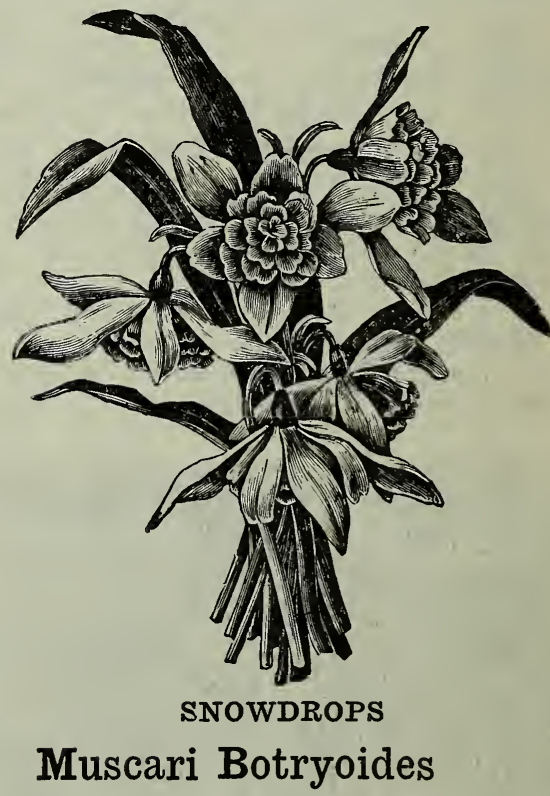

\section{Muscari Plumosus}

Feathered Hyacinths-An odd and interesting variety bearing spikes of beautiful purple flowers; hardy everywhere.

Each, 3c; doz., 25c; 100, $\$ 1.00$
Grape Hyacinths-Very pretty early spring blooming bulbous plants, succeeding well in almost any soil or situation. White, blue, light blue.

Each, 3c; doz, 25c; 100, $\$ 1.00$

"Heavenly Blue" - New Grape Hyacinth of distinctive type and rare coloring, delightfully fragrant, extra large, fine as a cut flower or for massing in border.

Postpaid, per doz., 20c; per $100, \$ 1.00$ 


\section{Crocus}

These charming little flowers bloom at a time when the ground is destitute of foliage or other flowers. This makes them most welcome, and they should occupy a prominent place in every garden. When planted in borders or beds in one or more colors, the effect is striking. No spring display surpasses that of the Crocus. The broad, wavy bands of golden yellow, striped, purple, or of pure white, when they expand their blossoms in February and March, are incomparable.

A desirable effect is produced by setting Crocuses here and there over the lawn. It is only necessary to lift the turf and insert the bulbs about two inches deep. They will care for themselves, blooming very early amid the grass, and dying down to the bulb in ample time to be entirely out of the way of the lawn morrer. Once planted, they will remain uninjured in the ground and bloom for years.

Plant from October to March, about three inches deep and about two inches apart in beds or borders. Indoor, the Crocus can be easily forced. Plant from six to a dozen bulbs in a shallow pot, keep cool and water well, treating same as Hyacinths.

\section{Named Crocus}

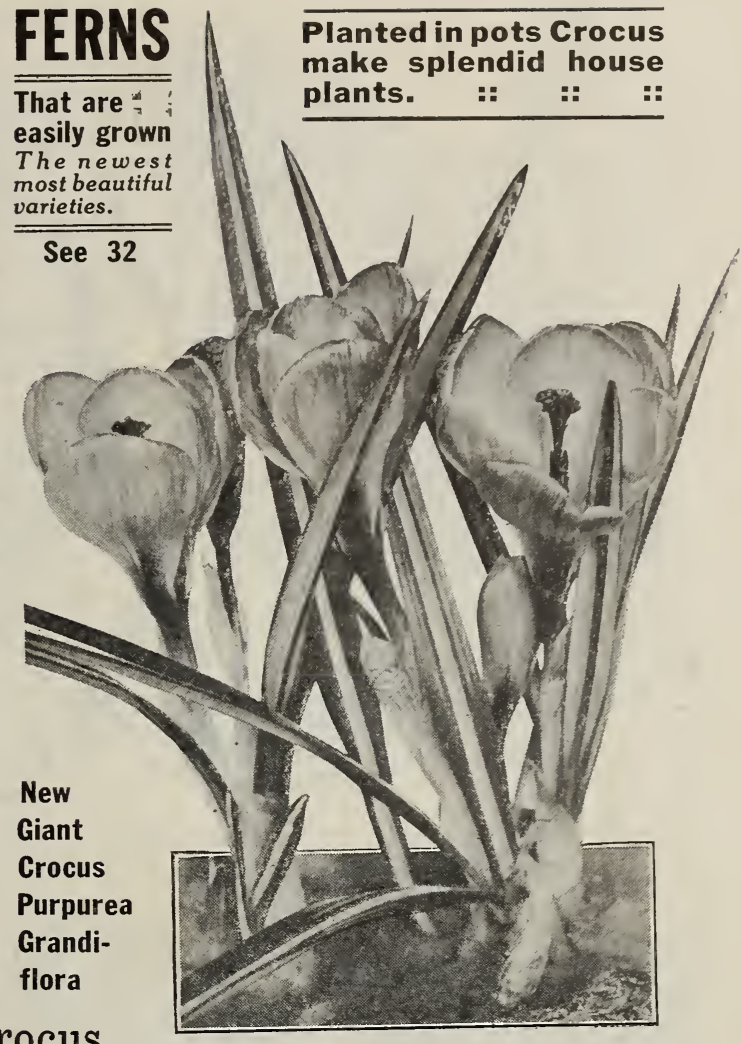

For forcing or special work the Named Crocus is best.

The three following varieties are new and improved sorts, the finest of their colors: Be sure to include them in your list.

King of the Whites-Mammoth snow white, truly the king of all white Crocus

Lothair-White with blue stripes, very beautiful and distinctive.

Purpurea Grandiflora-Bright purple, large, fine flower; best of its color.

Price of any of the above. Dozen, $15 \mathrm{c} ; 100, \$ 1.00 ; 1000 \$ 8.50$.

Baron Brunow-Bright purple, free bloomer, flowers large, extra fine.

Cloth of Gold-Golden yellow, slightly veined red, flowers large.

Cloth of Silver-Silvery white, striped lilac.
Mont Blanc-Large, pure white; one of the finest.

Mammoth Yellow-Yellow, selected bulbs of large size; finest blooms.

Prize, doz., 20c; 100, $\$ 1.25 ; 1,000, \$ 10.00$

Sir Walter Scott-White, striped with pur-

ple, the best striped, very large.
oted, dozen, $15 \mathrm{c} ; 100$, $\$ 1.00$.

Price of above, exeept where noted, dozen, $15 \mathrm{c} ; 100, \$ 1.00$.

\section{Mixed Crocus}

These separate colors in mixed shades are extensively planted for outdoor beds or borders. Our bulbs are all solid and sound and first size. We have four colors.
Assorted-Blue, striped, white or yellow.

Dozen, 10c; 100, 60c.

Mixed-All colors

Per 100, 50c.

\section{Anemones}

These bulbs produce a most beautiful and showy flower. The plant is neat and compact in growth. Foliage is very fine and elegantly cut. Culture same as for Hyacinths. For forcing indoors, plant three or four bulbs in a four-inch pot. Avoid too much heat.

Double blue, scarlet or mixed.

Each, 4c; doz., 35c

Single scarlet, blue, white or mixed.

Each, 3c; doz., 25c

\section{Giant St. Brigids}

New-Giant St. Brigids-A new race of Anemones far superior to any hitherto known. Flowers come double, semi-double and single, from 3 to 5 inches across and in many varied and brilliant colors, long stems, free blooming. Planted inside in the fall will flower during the winter or can be planted in open ground after danger of frost has passed. Try them. Price, Each, 5c; doz., 50c; 100, $\$ 3.00$ 


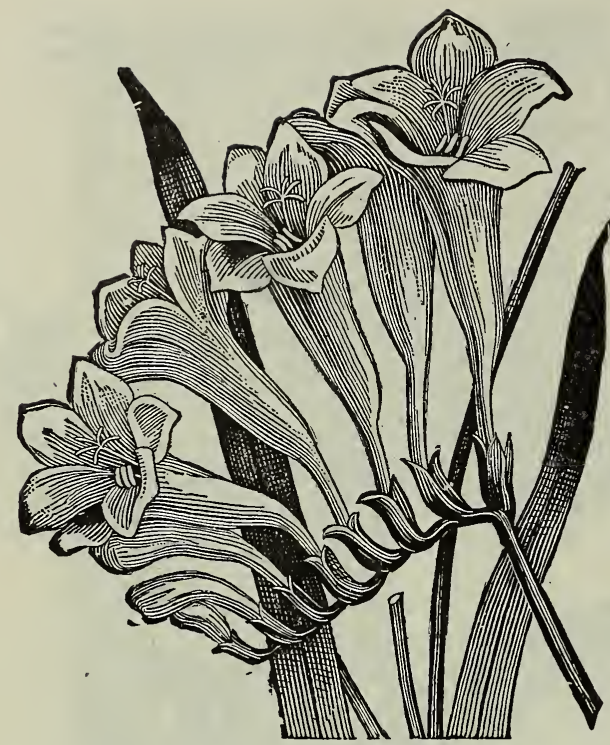

Freesia

\section{FREESIAS}

These popular winter blooming bulbs force readily, coming into bloom early, and by successive plantings will last throughout the season. Their handsome clusters of white flowers have a most delicious fragrance. Plant four to six in 4-inch pot.

\section{New Giant Freesia-Purity}

A grand new Freesia of giant size and good substance, pure white, a vigorous grower and.good keeper. First size bulbs.

Doz., 50c; 100, $\$ 3.50$

Refracta Alba-The flowers are pure white with a yellow blotched throat and are exquisitely fragrant.

First size bulbs.

Extra large bulbs.

Doz., 30c; $100, \$ 1.50$

Doz., 35c; 100, $\$ 2.50$

OUR RED CLAY FLOWER POTS ARE THE BEST MADE. WRITE F'OR PRICES ON LARGE IOTS.

\section{Cyclamen (Giant Persian)}

These are among our most beautiful and interesting winter and spring flowering bulbs for the window and greenhouse. Not only are the flowers of striking beauty, but the foliage is also highly ornamental. There are no plants better adapted for pot culture, and few that produce such a profusion of bioom; the flowers range through many shades of pinis, crimson, white, etc., some being beautifully spotted, and many of them delicately fragrant. Plant one bulb in a four or five-inch pot.

White, Carmine or Pink. Each, 25c; three, 60c; doz., $\$ 2.25$ Mixed Colors.

Each, 20c; doz., $\$ 2.00$

For Cyclamen Plants ready to bloom, in pots, see catalog.

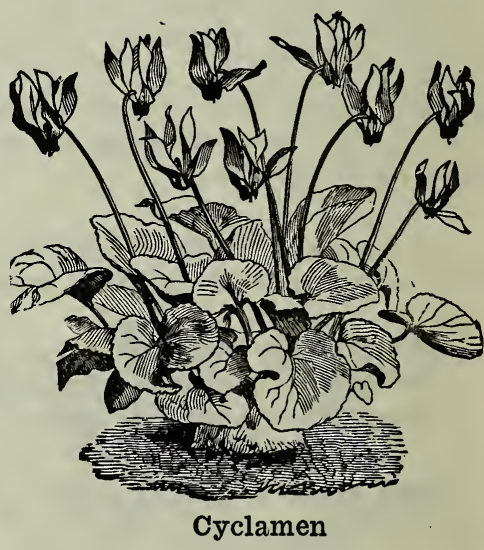

\section{Leucojum (Snow Flake.)}

Pretty bulbous plants allied to the Snowdrop, but of much stronger and bolder habit, growing from one to two feet high, in rich soil, and producing freely, beautiful large white flowers distinctly tipped with green, excellent for cutting. When once planted they take care of themselves, and should have a place in all hardy collections; can also be grown in pots. Leucojum Vernum (Spring Snowflake).

Leucojum Aestivum (the Summer Snowflake).

Each, $4 \mathrm{c}$; doz., $35 \mathrm{c} ; 100, \$ 2.00$

Each, $4 \mathrm{c}$; doz., $35 \mathrm{c} ; 100, \$ 2.50$

\section{Allium}

Neapolitanum-An excellent variety for winter flowering, extensively forced by florists for cut flowers. Its flower stems are 20 inches high, supporting a large cluster of delicate white starry flowers; sure to bloom splendidly in any window.

Neapolitanum Each, 3c; doz., 25c; 100, $\$ 1.00$ Mixed colors Each, 3c; doz., 20c; 100, 85c

\section{Chionodoxa}

They produce flower spikes bearing lovely Scilla-like flowers. They are perfectly hardy, and may be planted as an edging to a bed, or in masses; they flower with the Snowdrops and last a long time in perfection.

Lucilliae-Bright blue with large, clear white center.

Each, 3c; doz., 30c; 100, $\$ 2.00$

\section{Fritillaria Imperialis (Crown Imperials.)}

A stately, showy, early blooming plant, bearing large bell-shaped flowers of various shades of red and yellow, should be planted in deep, well enriched soil and not disturbed for years. The Crown Imperial is a very attractive garden flower. Fine Mixed, Each, 15, doz., \$1.50 


\section{Ranunculus}

Among dwarf flowers these are unrivaled for lovely form and bright and attractive colors, ranging through gorgeous shades of white, crimson, yellow, purple and black, many of them being beautifully marked with other shades. They flower profusely in puts in the house during the winter.

Turban, Mixed-Paeony-formed flowers, large and early, vivid colors and compactly double.

Each, $3 c$; doz., 25c; 100, $\$ 1.50$ flowers.

Giant French, Mixed--Immense and gorgeous, loosely formed double

Persian, Mixed-Rose-shaped flowers, very double and rich.

Each, 3c; doz., 25c; 100, $\$ 1.00$ Scillas

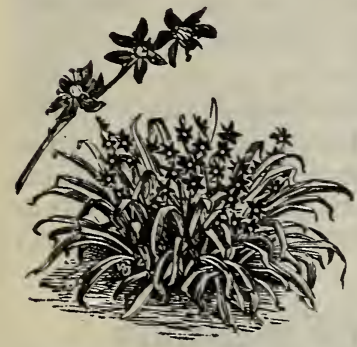

SCILLA SIBERICA

Siberica-This is one of the prettiest of early spring blooming bulbs, of dwarf habit, with sprays of exquisite rich blue flowers. Grown in masses in conjunction with Crocus, Chionodoxas and Snowdrops, the effect is charming; fine for forcing. $\quad$ Each, 3c; doz., 25c; 100, \$1.75

Campanulata-A beautiful spring flowering bulb, producing, before the leaves appear, spikes of bell-shaped flowers in blue, white and pink.

White, blue or pink.

Each, $4 c$; doz., 35c; 100, $\$ 2.00$

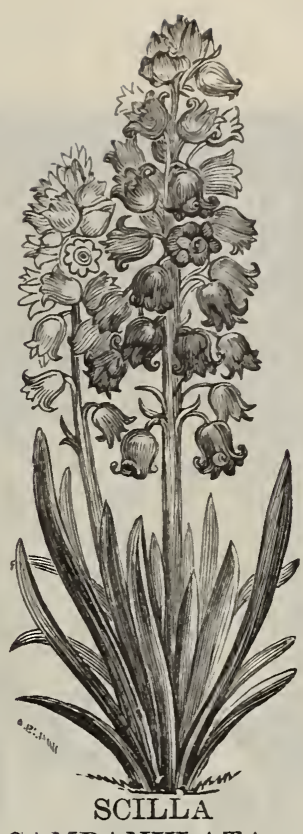

CAMPANULATA

\section{Oxalis}

Charming little half-trailing or bushy plants, particularly adapted for pot culture and hanging baskets; the foliage alone is very attractive, and when in flower they are exceedingly pretty.
Fine mixed
2 for $5 c$; doz., 20c: $100,75 c$

Bermuda Buttercup-Bears in profusion, bright, golden yellow flowers all winter. One of the finest winter blooming plants ever introduced for pots, baskets and vases; produces a mass of pretty foliage covered with hundreds of buds and flowers at one time. For forcing, plant the bulbs in light, rich soil and set in a cool place for several days, then remove to a warm, sunny window.

Single

Each, 4c; doz., 35c; 100, $\$ 2.00$

Grand Duchess-A California variety of great beauty; of dwarf, sturdy growth; free flowering and very desirable. Pink, lavender; white or yellow.

Each, 4c; doz., 35c; 100, $\$ 2.00$

\section{Erythronium (Dogstooth Violet)}

\section{Dens Canis Grandiflora, Mixed.}

Fine hardy plants with charmingly variegated foliage, bearing lily-like blossoms of different colors; prefer moist situation with partial shade; grow well in pots for winter blooming. Each, 5c; doz., 40c; 100, $\$ 2.50$

\section{Eranthus Hyemalis}

Winter Aconite-The first flower of the year, often coming before the snow is gone, covering the ground with gilt spangles of flowers as early as February; succeeds in any soil or situation; remains in flower for weeks. Each, 5c; doz., 25c; 100, $\$ 1.50$

\section{Drnithogalum}

Arabicum-A beautiful plant for forcing in the house. The leaves are long and narrow, flower spikes about 18 inches high, bearing large clusters of beautiful, pearly-white flowers which have a jet-black center. Plant one bulb in a four-inch pot, same as Hyacinths. Extra choice bulbs.

Each 10c; doz., $\$ 1.00$

Umbellatum--Like the above, only pure white. Known as "Star of Bethlehem."

Each, 5c; doz., 40c

\section{Sparaxis}

A beautiful class of bulbs allied to the Ixias, and requiring the same treatment, producing spikes of flowers of the most exquisite and brilliant flowers.

Very fine mixed Each, 3c; doz., 25c; 100, $\$ 1.25$

\section{GERANIUMS}

We offer the most complete assortment of most useful varieties

For house plants and bedding.

SEE PAGE 31

\section{Triteleia Uniflora}

Spring Star Flower-A pretty little bulbous plant for either pot culture or the open border, bearing fragrant star-shaped flowers of a delicate blue-white color.

Each, 3c; doz., 20c; 100, $\$ 1.50$ 


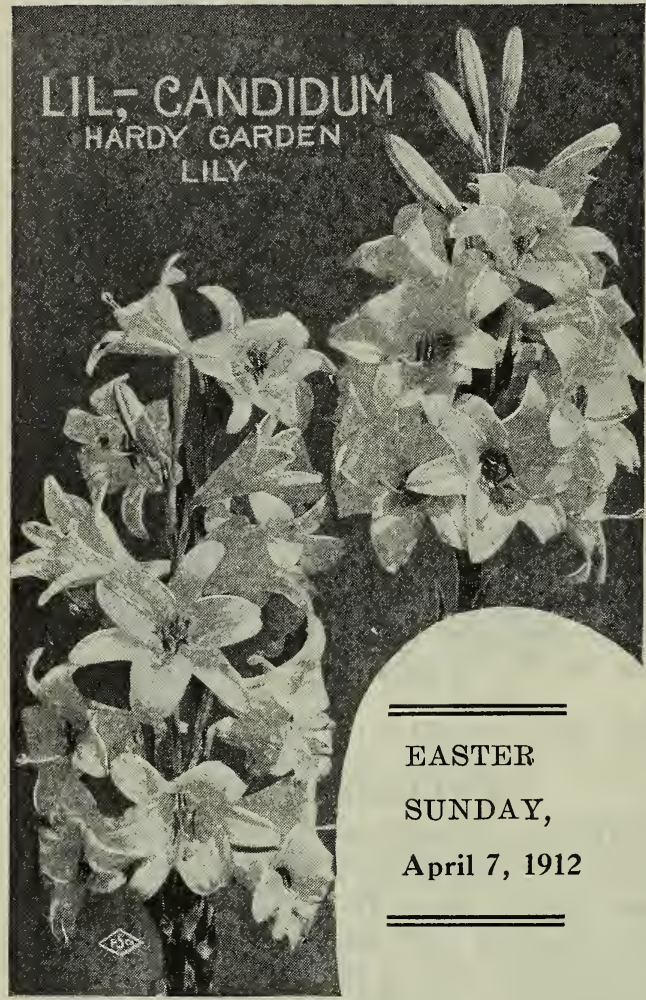

Your order for Bulbs is not complete without Lilies, the most fragrant, beautiful and stately of outdoor flowers, requiring less care and attention than any other plant. After Bulbs are set out they should remain undisturbed for five or six years. They will increase in size, beauty and number of flowers with practically no attention, our coast climate being perfectly suited to their requirements, and once established they rival the famous product of Japan, but as we do not grow them commercially, we have to depend on Japan and Bermuda for our best bulbs.

All varieties we offer are perfectly hardy, and should be planted outdoors during the fall or early spring. They flower each year from June to October. We have selected the finest types that bloom freely and in the various kinds listed below you will find Lilies suitable for every purpose.

\section{New Lilium Formosum}

A wonderful new Easter Lily from the Island of Formosa, extremely vigorous, free flowering, bearing more and better blooms than any other Longiflorum variety. Is also very early and absolutely free from disease.

Mammoth Bulbs.

Each, 20 c; doz., $\$ 2.00 ; 100, \$ 16.00$

Large Bulbs. Each, 15c; doz., $\$ 1.50 ; 100, \$ 12.00$

- Lilium Harrisi-Our leading florists, after careful comparative tests, have discarded the Bermuda Harrisii in favor of the new Lilium Formosum, which is earlier, produces more and better flowers and is entirely free from disease. We always recommend them and have dropped the Bermuda Harrisii from our list.

\section{Lilium Longiflorum MULTIFLORUM}

Very much like the Lilium Harrisii, but preferred by many to that variety, as they are stronger and less liable to disease. They do not come into bloom quite so early, but the flowers are of better substance and more extensively used by florists for forcing for Easter and for cut flowers. When grown in the open ground they bloom in June and July. Can be planted in the spring or fall.

Mammoth bulbs .........................Each, 20c; doz., $\$ 2.00 ; 100, \$ 15.00$ Large bulbs $\ldots \ldots \ldots \ldots \ldots \ldots \ldots \ldots \ldots \ldots \ldots \ldots \ldots \ldots$ Each, $15 c$; doz., $\$ 1.50 ; 100, \$ 10.00$

\section{Lilium Longiflorum GIGANTEUM}

Of grand size and substance; superior to the Multiflorum but forces a little later; especially fine for open ground.

Mammoth bulbs ............................Each, 20c; doz., $\$ 2.25 ; 100, \$ 15.00$ Large bulbs $\ldots \ldots \ldots \ldots \ldots \ldots \ldots \ldots \ldots \ldots \ldots \ldots \ldots \ldots \ldots$ Each, $15 \mathrm{c} ;$ doz., $\$ 1.75 ; 100, \$ 12.00$

\section{Lilium Candidum}

This is the ever popular, fragrant, snow-white, hardy garden Lily. It grows four to five feet high, and blooms in the open ground in June. When grown in bold masses or in rows these Lilies are especially effective. The brilliancy of their snow-white flowers against surrounding greenery of shrubs, grass and trees is very telling. See cut. Our stock is imported from the Azores, the finest obtainable; should be planted early.

First size. Each, 20c; doz., \$2.00; 100, $\$ 12.50$. Second size. Each, $15 \mathrm{c} ;$ doz., $\$ 1.50 ; 100, \$ 10.00$

FLORISTS AND COMMERCIAL GROWERS: We carry the largest line of Florists' Supplies in the Northwest. Prompt deliveries at right prices. A trial order will convince. Send for trade list. 


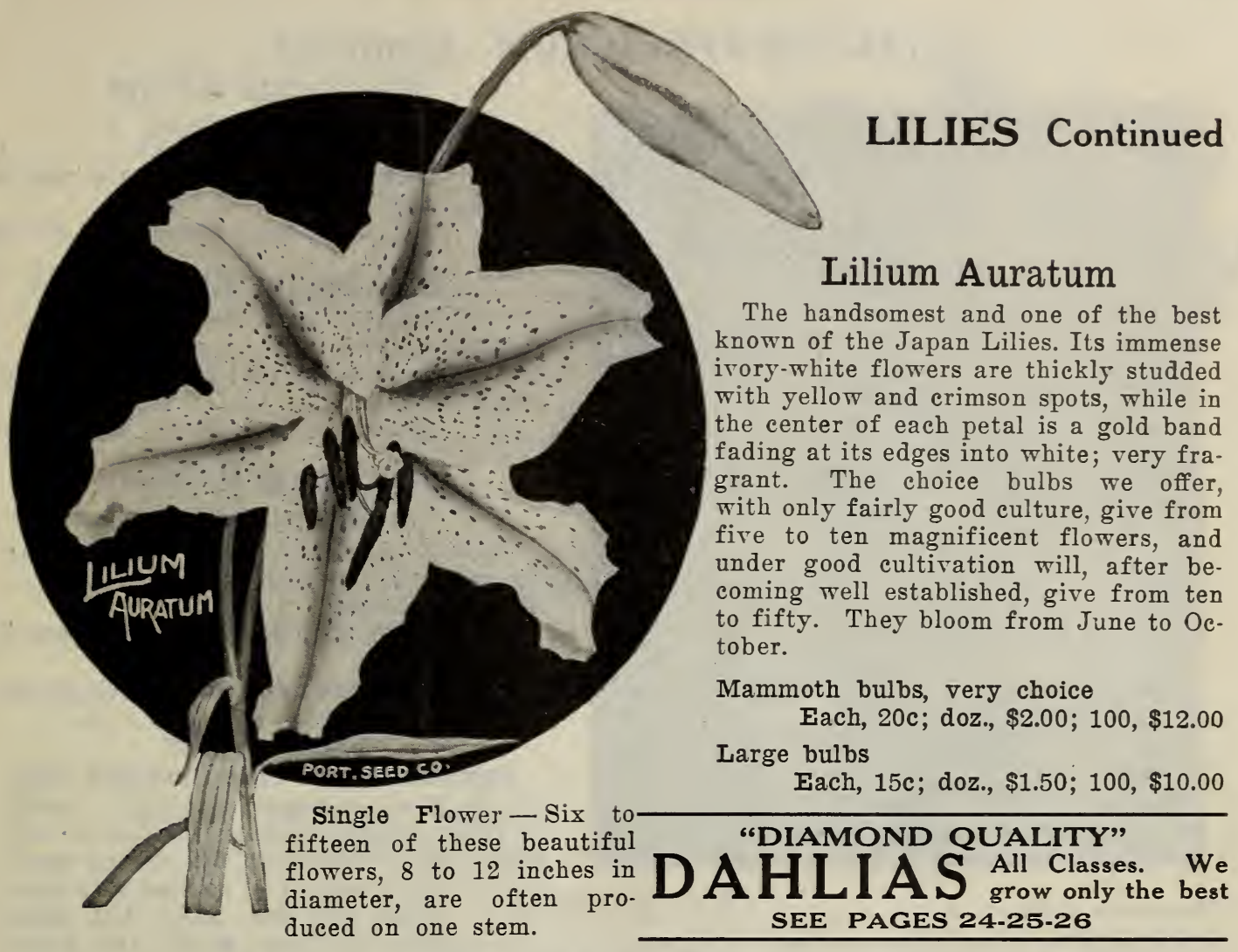

\section{Auratum Rubro Vittatum}

Giant flowers-pure white, beautifully spotted and with deep crimson stripe through center of petal. Truly magnificent.

Each, $75 \mathrm{c}$; doz., $\$ 7.50$, postpaid

\section{Auratum Pictum}

Same as Auratum, except gold band shades into bright crimson at margin. A rare and beautiful lily.

Each, 35c; doz., $\$ 3.00$, postpaid

\section{Auratum Platyphyllum}

This is without a question one of the most wonderful Lilies in cultivation. The leaves are very long and broad, and the stems attain a height varying from seven to ten feet. The flowers are similar in color to Auratum, heavily spotted, but are much larger, the petals more overlapping. and of greater substance. See illustration.

Mammoth bulbs........Each, 25c; doz., $\$ 2.50 ; 100, \$ 17.50$ Large bulbs.......... Each, 20c; doz., \$2.00; 100, $\$ 15.00$

\section{Lilium Speciosum}

No words can overstate the brilliant beauty of this charming class. Its six broad, pure white, or pink petals thickly dotted with rose or carmine spots, and the graceful - form, brilliant color and exquisite fragrance make this one of the most effective and desirable of the lily family. They are profuse bloomers and last for days after being cut and put in water.

\section{New Lilium Magnificum}

As its name-implies, this new Lily from the southern island of Japan, is the most magnificent of the wonderful Speciosum Lilies. It is of the Rubrum variety, closely allied to Speciosum Melpomene, but of much richer color and grander size. Should be in every collection. Price, Large bulbs....... Each, 25c; doz., $\$ 2.50 ; 100, \$ 18.00$

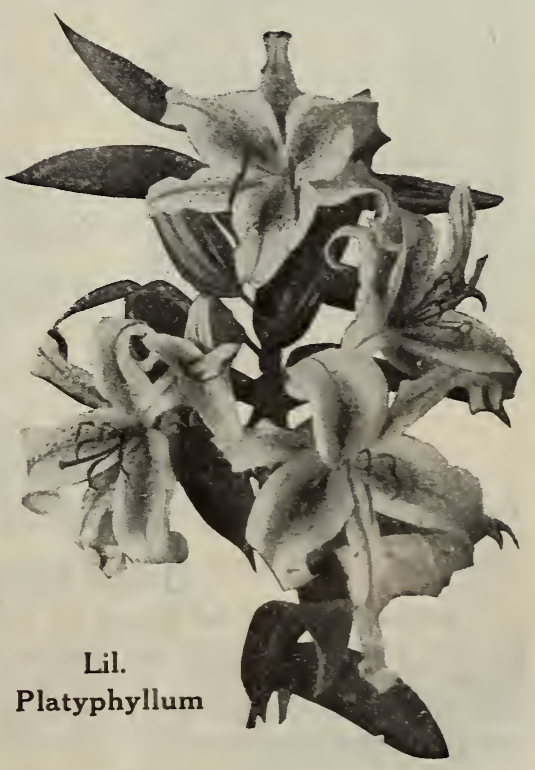




\section{LILIUM SPECIOSUM-Continued}

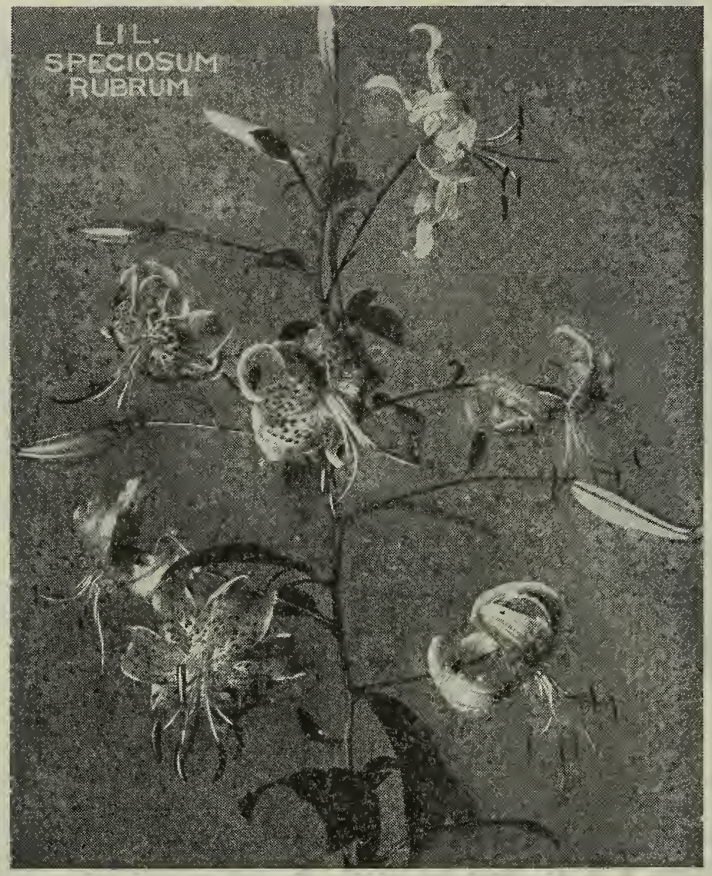

\section{Speciosum Album}

Pure white, flowers freeıy.

Mammoth bulbs,

Fach, 25c; doz., $\$ 2.50 ; 100, \$ 20.00$

Large bulbs,

Each, 20c; doz., $\$ 2.00 ; 100, \$ 15.00$

\section{Speciosum Rubrum}

White, with dark rose spots.

Mammoth bulbs,

Large bulbs,

Each, 20c; doz., \$2.00; 100, $\$ 15.00$

Each, 15c; doz., $\$ 1.50 ; 100, \$ 10.00$

\section{Speciosum Rubrum Melpomene}

White, shaded rich blood crimson, heavily spotted; very rich and showy. Mammoth bulbs, Large bulbs,

Each, 25c; doz., \$2.50; 100, $\$ 20.00$

Each, 20c; doz., $\$ 2.00 ; 100, \$ 15.00$

\section{Tiger Lilies}

Tigrinum Flore Pleno (Double Tiger Lily)-This is a magnificent Lily, of stately habit, bearing immense clusters of very large double flowers on tall, strong stems, color bright orange real spotted with black

Mammoth bulbs Each, 20c; doz., \$2.00; 100, $\$ 12.00$

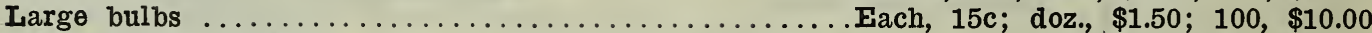

Tigrinum Splendens (Improved Single Tiger Lily)-Has very large flowers of excellent form; color orange salmon, with dark spots, hardy and free bloomer.

Mammoth bulbs .............................Each, 20c; doz., \$2.00; 100, $\$ 12.00$ Large bulbs ................................ 15c; doz., $\$ 1.50 ; 100, \$ 10.00$

\section{Washingtonianum (Mt. Hood Lily.)}

A beautiful Lily, native of Oregon; flower large, of open form; white, tinted with lilac; grows three to five feet high; very fragrant." Hardy everywhere.

Choice bulbs .................................... Each, 25c; doz., \$2.50

\section{Lilium Elegans (Extra Red.)}

Brilliant velvety red, large and beautiful; one of the finest of the Elegans class.

Each, 20c; doz., $\$ 2.00 ; 100, \$ 15.00$

\section{Calla Lilies \\ Lily of the Nile}

Calla Ethiopica-Our well-known' White Calla in its rare and stately beauty has few equals as a pot plant, and nothing is easier to grow. Plant one bulb to six-inch pot, give an abundance of water, light and heat, and the result will be most satisfactory,

We offer dry roots (from September on), as they are superior for forcing and winter flowering purposes. They come into bloom quickly.

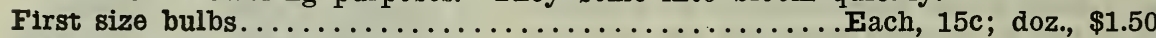
Extra size bulbs............................ Each, 20c

\section{Arum Sanctum}

The Black Calla-A rare and interesting plant, grows well and flowers freely; always attracts much attention. Each, $40 \mathrm{c} ; \mathrm{doz} ., \$ 4.00$

\section{Calla Elliotiana}

Yellow Calla-The finest of the yellow Callas, growing to perfection under ordinary pot culture. Treat same as White Calla, Flowers are a deep rich golden yellow-4 to 5 inches in diameter, and last a long time after opening. Foliage is a beautiful deep green, spotted silvery white; a grand novelty. 
“'DIAMOND QUALITY.',

\section{Lily of the Valley}

\section{Fancy Berlin Pips}

One of the most satisfactory and charming spring flowering plants, producing in profusion its delicate bell-shaped, delightfully fragrant, white flowers. "Valleys" thrive in any common soil, are perfectly hardy, and will succeed in shady situation. They can be left undisturbed in the open ground, where they will increase from year to year, and are most charming in beds or borders around the lawn. For outdoor planting and winter forcing, pips and clumps are ready November to March.

Selected Pips, for forcing indoors or planting outside.

Each, 5c; doz., 40c; 100, $\$ 2.50$

Strong Clumps for outdoor planting.

Each, 30c; doz., $\$ 3.00$

NOTE-Clumps can only be sent bJ express or freight at buyer's expense.

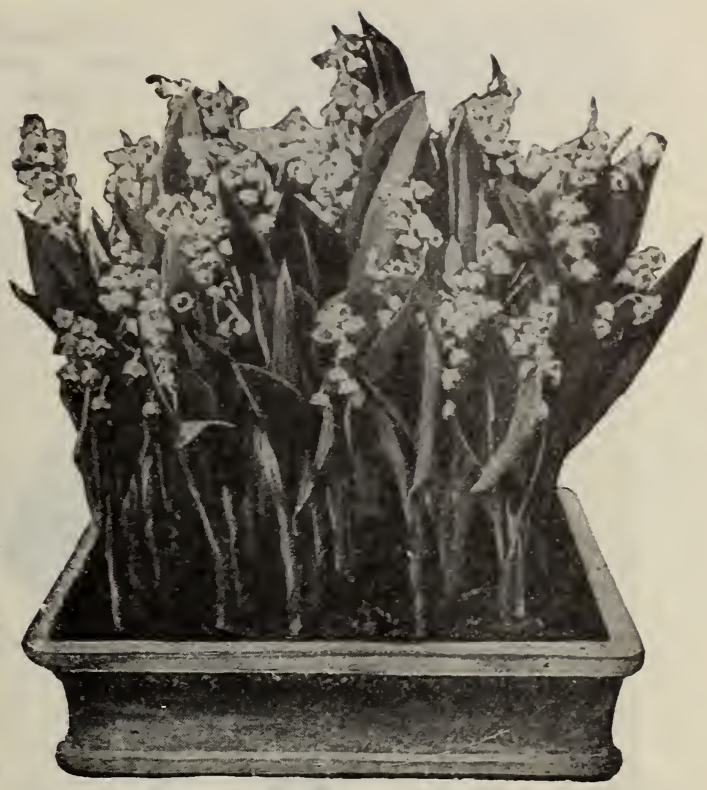

LILY OF THE VALLEY.

Florists wishing a really first class "Valley," write us for prices

\section{AMARYLLIS}

All Amaryllis produce lily-like flowers varying in color from the $\mathrm{r}_{1}$ chest crimson and scarlet to pure white. The bulbs we offer are of extra large size and will produce handsome flowers either in or out of doors.

\section{Amaryllis Halli \\ (Licoris Squamigera.)}

A new hardy pink Amaryllis-like flower, of exquisite beauty, producing its attractive green foliage in the early spring, dying down suddenly in July, but in-three or four weeks the flower stalks shoot up as if by magic, to a height of two or three feet, developing. a cluster of large and beautiful lily-shaped flowers three to four inches in diameter; color is a most charming shade of delicate lilac pink with dainty blue shading. Fall planting is best, and bulbs should be buried about four inches. A pleasing novelty, well worthy a trial.

Each, 20c; doz., $\$ 2.00$

\section{Johnsonii}

Johnsonii (Bermuda Spice Lily) - An old favorite The immense trumpet-shaped flowers, which measure six to eight inches across, are borne on strong, fleshy stems and are a rich velvet crimson, each petal having a broad white stripe, contrasting beautifully with the deep red color.

Choice bulbs, each, $35 \mathrm{c} ; 3$ for $90 \mathrm{c}$

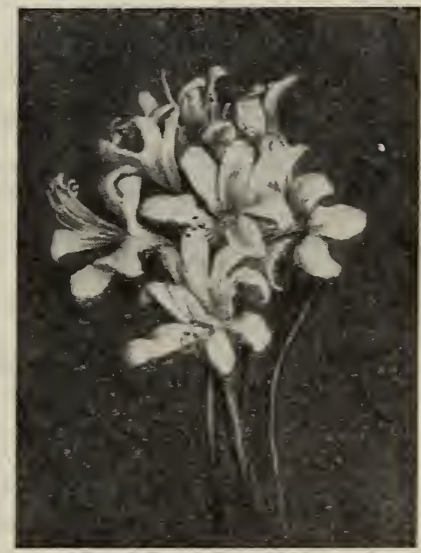

LICORICE SQUAMIGERA.

\section{Belladonna Major}

Belladonna Major (Belladonna Lily)-Autumn blooming variety of extreme beauty and fragrance; the spikes grow from two to three feet high, each carrying from six to twelve beautiful flowers, "sweet as lilies," of silvery white, flushed and tipped with rose.

Choice bulbs, each, 25c; 3 for $60 \mathrm{c}$

\section{Vittata Hybrids}

Vittata Hybrids-New varieties of exceptional beauty; flowers large, elegantly colored and marked. Good for early forcing.

Each, 40c; 3 for $\$ 1.00$ 


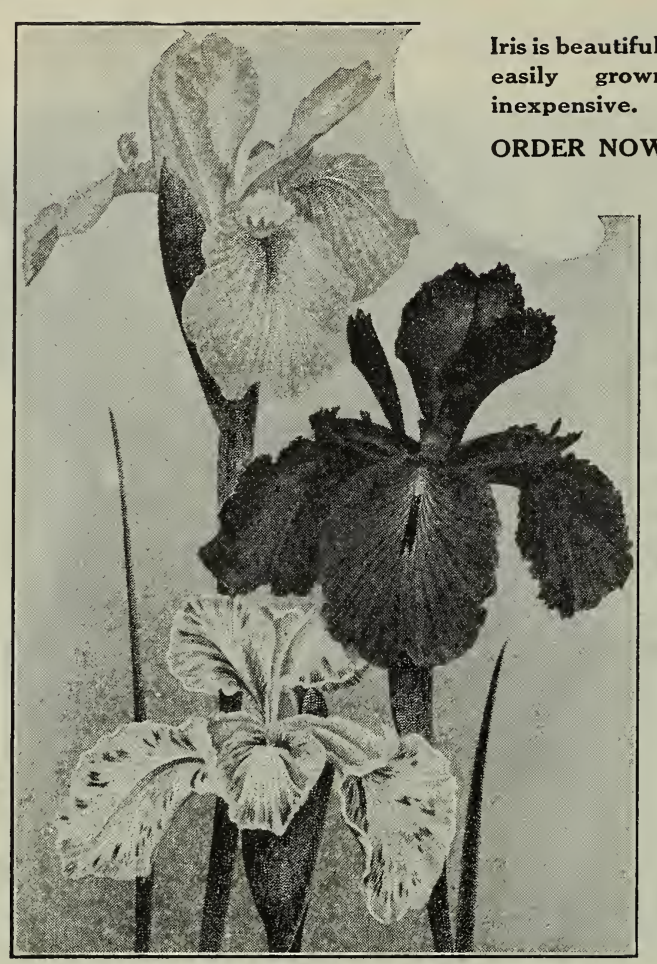

\section{Japanese Iris}

(Iris Kaempferi).

Japan Iris is the largest and most wonderful of the Iris family, no flower of any kind surpassing its rare beauty of form, brilliancy and variety of coloring, ranging from snowwhite through maroon, violet and deep blue; striped, variegated, veined and blended in the greatest profusion, producing effects that are truly marvelous and indescribable. Blossoms early summer. Japan Iris succeeds best in a moist location. but will thrive in any good garden soil. Plant 3 inches deep, about 4 inches apart; divide the clumps every two years. Fertilize established beds while dormant, using stable manure, but do not apply after growth starts. There are hundreds of varieties, from which we have selected the following:

Gekka-no-nami-Dense pure white, yellow blotches.

Ho-0-jo-Ruby crimson, primrose blotches, surrounded with white halo.

Hana-no-nishiki-Brilliant claret red, penciled white, purple orange blotches.

Sofu-no-koi-White splashed, blotched and speckled sky-blue, primrose blotches.

shimoyo-no-tsuki-White, yellow blotches at base of petals; 6 large petals.

Uji-no-hotaru-Purple overlaid with siryblue, orange blotches, 3 petals.

Yezo-nishiki-Deep rich crimson, mottled and blotched white, 3 standards same color.

Yomo-no-umi-Lavender blue; distinct and beautiful; 6 petals.

Kuma-funjin-Purple overlaid with navy blue, 2 standards, very, large orange blotches.

Kumoma-no-sora-White, with a strongly marked sky-blue zone and mottled in the same shade.

Kumo-isho-Purple, margined gray, yellow

blotches, surrounded with velvety crimson.

Kumo-no-obi-Dark lavender purple, large handsome flower, 3 petals.

Nained Varieties.

Fach, 20c; doz., $\$ 2.00 ; 100, \$ 15.00$

Mixed, good assortment.

Fach, 15c; dor., 81.50; 100, 810.00

\section{IRIS}

$\mathbf{M}$

AGNIFICENT plants for the garden. They bloom profusely and are exceedingly showy and fragrant. The colors are brilliant and cover a wide range of different shades and combinations. In the open ground they are perfectly hardy, increase rapidly and make a magnificent display either in clumps or borders. They do best in rich, moist soils. If soil is light, depress the beds a little below their surroundings; this helps to collect and hold the moisture. Plant in the fall or early spring.

\section{Spanish Iris}

Spanish Iris is the most useful and satisfactory Iris to grow, requiring no unusual condition or treatment to insure success, growing to perfection in any good garden soil They are vigorous and hardy, early and free blooming, keeping well when cut; can also be forced easily, being great favorites with florists.

Spanish Iris comes in the most delicate and beautiful shades and colors, from white, through dainty blues to lavender, dark blue, pure rich yellow, etc. Bulbs are inexpensive and we urge you to plant freely.

Blooms in early June two weeks before the English variety. The varieties listed are best of their colors.

Blanche rleur-A grand white flower of great substance. The best white for forcing or outdoor culture.

Cajanus-A magnificent tall golden yellow, free blooming, good keeper; best yellow Iris in cultivation, either to force or grow outside.

Count of Nassau-The finest dark blue Iris. Has an agreeable honeysuckle perfume.

ring of the Blues-Finest of the dark blues.

Iouise-A beautiful shade of light blue, large, splendid flower

Fmperor-A splendid new light yellow of great merit. all.

Darius-A pleasing light blue-earliest of

Finest named varieties.

Each 3c; doz., 30c; 100, $\$ 2.00$

Mixed, select, all colors.

Fach, 3c; doz., 20c; 100, $\$ 1.50$

\section{GERMAN IRIS.}

German Iris is one of the best of the early spring flowers, is hardy everywhere, and if planted in a moist situation or watered freely, will produce magnificent orchid-like blooms of great size and delightful fragrance. Comes in charming color effects in blues, browns, yellows, purples, white.

Pallida Dalmatica-Extra large, lovely true lavender, delightful fragrance, free flowering, fine for massing or as a cut flower.

Florentine Alba-White.

Celeste-Satiny blue.

Spectabilis-Violet purple.

shakespeare-Bronze violet.

Mars-Light yellow and cream.

Choice roots for fall planting. Each, 15c; doz., \$1.50; 100, $\$ 10.00$

\section{ENGLISH IRIS (Iris Anglica).}

English Iris is almost as large as the Japanese variety and also comes in a marvelous range of colors and variegations, is extremely hardy, growing 18 inches to 28 inches high, coming into bloom just before the Japanese Iris. Like all Iris, a moist situation is preferred, but any good soil will grow them splendidly. Plant 3 to 4 inches apart. English Iris is one of the best for naturalizing.

MONT 'BIANC-Largest and finest. Pure white. $\quad$ Fach, 6c; doz., 60c; 100, $\$ 4.00$ Assorted colors, 10 best varieties.

Each, 4c; doz., 40c; 100, $\$ 2.50$ Fach, 3c; doz., 30c; 100, $\$ 2.00$ 


\section{BEGONIAS-Tuberous Rooted}

From their early first blooming until cut down by frost, Tuberous Begonias display a mass of bloom of most gorgeous and brilliant coloring. They are distinct and unique, their giant flowers fully six inches in diameter, in wonderful shades of yellow, bronze, white, reds, pinks, etc., with thick waxy petals and grand ornamental foliage, never failing to excite the wonder and admiration of all who see them. There are four types, Single. Double, Frilled and Crested.

CUITURE-The soil should be rich in leaf mould, or well-rotted manure, a little sand being beneficial Start the bulbs inside in the early Spring, and transplant when danger of frost is past. They should be lifted in the fall before frost, dried and stored in sand in a cool place.

A good way to start Begonias and Gloxinias is to put the bulbs on a layer of moss in a box or flat and cover with another layer. Keep moist, but not too wet; temperature about 70 degrees; this starts both top and roots, then pot for root development before transplanting outside. See page 73 for Gloxinias.

SINGLE FLOWERING.

These are of immense size, erect, flowers of great substance, free blooming and very lasting. Come in eight separate colors, copper, canary, orange, crimson, rose, pink, white and salmon.

Price, each, 10c; doz., 85c; $100, \$ 6.00$ CRESTED.

This remarkable strain comes in all the finest colors, and the flowers are as large as the largest singles. The petals, of great substance, carrying on their upper surface a crested formed cockscomb, which is a very attractive and interesting addition to the flower. Price, separate colors,

Fach, 20c; doz., \$2.00; 100, $\$ 15.00$ MIXED.

Our Diamond Mixture, containing all of above sorts. $\quad$ Per doz., \$1.50; $100, \$ 10.00$

Our Begonias and Gloxinias come from Ghent, Belgium, where finest bulbs are grown.

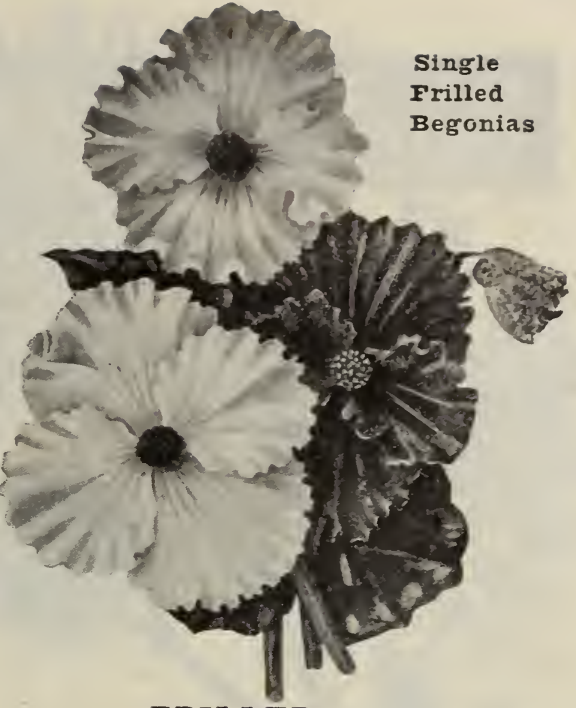

FRILLED.

(See Cut.)

Single frilled Begonias differ from the plain singles only in having the heavy frill or fringe on the edges of the petals. They have the same range of color, handsome foliage and free flowering habit. Separate colors.

Fach, 20c; doz., $\$ 2.00 ; 100, \$ 15.00$

\section{DOUBLE FLOWERING}

Many charming effects are found in the double varieties, they being often as full and beautiful as a rose, some of the white varieties resembling giant carnations. Price, separate colors. $\quad$ Fach, 15c; doz., \$1.50; 100, \$10.00

\section{CANNAS}

TW $\mathrm{z}$ are extensive growers of Cannas, and the following sorts are newer and better types that will give best results in our climate. Cannas require a rich, moist soil and should not be planted until all danger of frost is past. They are quick growers and the new flowering sorts bloom continuously until frost.

Inexpensive, luxuriant; these charming ornamental plants produce rich tropical effects that cannot be excelled, and the grand new varieties now offered are equally valuahle for the beauty of their bloom.

Iet us know your requirements. We ean supply the correct variety.

Prices: Except where noted, bulbs or plants, in season, each, $20 \mathrm{c}$; dozen, \$2.00, postpaid.

AIICE ROOSRVEIT-Deep crimson, compact green foliage; similar and superior to Alphonse Bouvier. Height 4 to 5 feet.

AIIFMAINIA-Light green, compact foliage, orchid type of flowers, bright golden lemon center marked and spotted terra cotta; height 4 to 5 feet.

JPAN TISSOT-Brilliant vermilion; green foliage; fine; 3 to 4 feet.

KING HUMBERT-In this grand new orchidflowered Italian Canna we have a combination of the highest type of flower with the finest bronze foliage. Its mammoth flowers, in heavy trusses, are a brilliant orange-scarlet, with bright red markings, foliage is broad and massive and of a rich coppery bronze with brownish green markings; bold and effective; has no equal; 5 to 6 feet.

IOUISIANA-A strong, vigorous grower, producing a dense mass of glossy green foliage and vivid orange-scarlet flowers of mammoth size; orchid type; height 4 to 5 feet.

MISS BRUNMrR-Bright light yellow flaked carmine; excellent. 4 to $4 \frac{1 / 2}{\text { feet. }}$

MRS. KATI GREY-Foliage green; flowers very large; rich orange-scarlet, marbled with red, yellow in the throat; 5 to 6 feet.

W. ‥ COTTRIII-Pink, suffused orange; foliage green, marginal brown; $31 / 2$ feet; fine.

Price, each 25c.; doz., $\$ 2.50$
PRISIDFNT MrYFR-Large, rich, bright scarlet flowers; dark bronze foliage, 3 to $3 \frac{1 / 2}{2}$ feet; extra good.

OUEFN CFARIOTTI-Scarlet, widely bordered, yellow, early, dwarf, compact; 3 feet. QUEFN OF BIAUTY-A deep rich pink, similar to Louise, but darker. 4 feet.

RED CROSS-Magnificent rich dark-brown foliage, of massive sturdy habit: flowers a brilliant glowing orange-red; height 3 to 4 feet.

WYOMING-A grand orchid-flowering Canna, with deep bronze foliage and immense golden orange flowers, suffused with a blush of crimson; height 4 to 5 feet.

Price, each, 25c.; doz., $\mathbf{\$ 2 . 5 0}$

RICHARD WAILACE-Light canary yellow flowers of extra large size and good substance, free blooming, vigorous; green foliage; one of the best of the grand new flowering cannas; 4 feet.

BOSIA GIGAITPA-Finest of the new pinks, the rich deep rose colored flowers often measuring five inches across are borne in the greatest profusion, nothing finer has ever been offered; foliage green; 4 to 5 feet.

BUTTrR-CUP-A free blooming, larre flowering, green foliaged bedding canna of fine thrifty habit, bearing immense waxlike flowers of pure buttercup yellow; 3 feet; best of its class. 

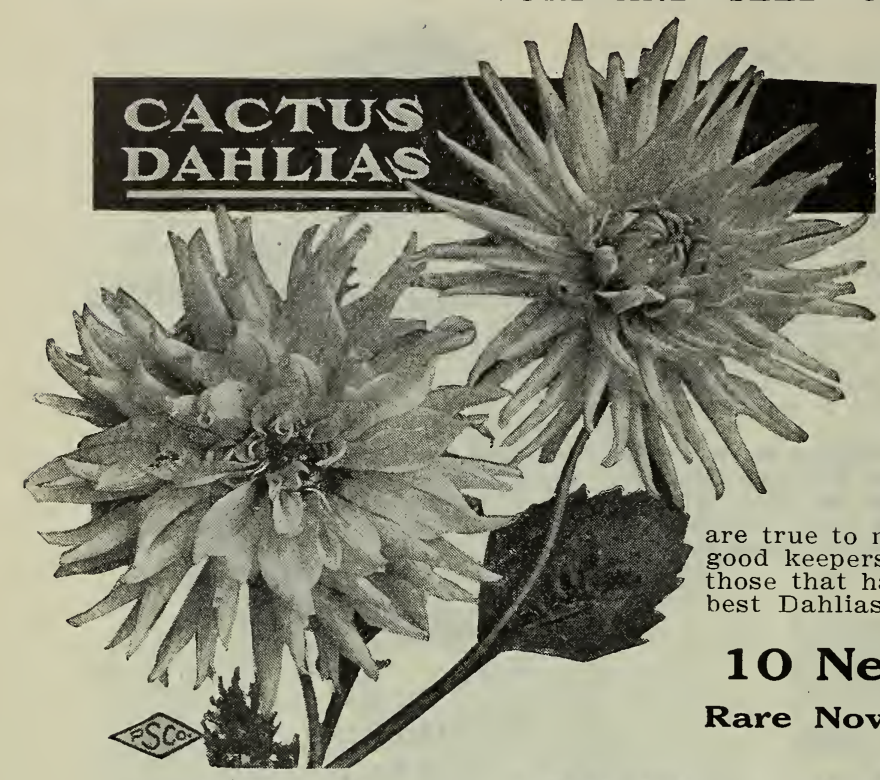

\section{DAHLIAS}

OUR "Diamond Quality" Dahlias registered prize winners from the best American English and continental producers, will prove a revelation to all growers. The rapid evolution of the types and varieties, under scientific culture is the marvel of the floral world, and their possibilities can hardly be magined.

Though the genus comprises but few species, Dahlias have a wider range of color than any other flower and for intense brilliancy and beauty have never been equaled.

We grow our own Dahlias, offering only those we know to be valuable. Our descriptions are made in the field, not copied or guessed at, and our Dahlias are true to name. They are also erect bloomers and good keepers, for in this list we have included only those that have withstood our severe field trials, the best Dahlias from the most famous growers.

\section{Newest Cactus Dahlias}

Rare Novelties of Real Merit that Will not Disappoint You.

Desdemona-An exquisitely beautiful, daintily formed flower of the Dorothy Oliver type, but a larger, better Dahlia in every way; the central shade is a lovely creamy canary shading to white at ends of the slender, in-curved petals ; flower very full, erect, borne on long stems above the dark, rich foliage; a vigorous free bloomer. Dornroschen-A most unique and remarkable Dahlia coming in variable shades, carmine to brilliant red, shading to delicate pinks with blush suffusions; all degrees of color from the bright red self colors to the lighter variations, on the same plant; a dainty, perfectly formed, fully double flower; long slender petals, beautifully in-curved and quilled; large and free blooming; long stems, erect; compact bush.

Genoveva-An elegant distinctive flower of a pale canary yellow, with a beautiful faint greenish tinge suffusing the entire flower, which is large, with well filled incurving petals; erect, long stems, free blooming; approaches paeony type in its twisted formation; bushy, compact, vigorous grower.

Harmonie-A fine, full flower, chamois yellow center, outer petals a soft salmon red with lighter tips; a most elegant and free blooming Dahlia; erect grower, good stems, a great improvement over Aschenbroedel.

Lily Seismeyer-A rare shade of deep orange buff, with rich light yellow center; a very unusual and beautiful combination; petals are of great substance; blooms large, erect, on long stems; is very early, free blooming, and one of the most lasting when cut. paid. Single plants or roots, each, $50 \mathrm{c}$

Modell-This is truly a model Dahlia with a coloring all its own. A beautiful clear waxy yellow, with a delicate plum blush sheen over tips of petals; a dainty, lovely flower of large size, perfect form, petals incurving, erect on long stems; one of the best bloomers and most vigorous growers ever produced. Add Modell to your collection.

Mauve Queen-A beautiful true lavender with lighter center, full flower with finely quilled petals; beautifully formed, incurved; an erect grower, long stems, vigorous, free blooming; a grand exhibition flower and one of the best introductions in years.

Othello-A glorious full, large flower of deepest, richest crimson, center almost black; finest true cactus form; petals of great substance, free and continuous bloomer, producing the most perfect flowers; long stems, erect, good keeper; an ideal flower in every way and one of the earliest.

Vulcan-A brilliant fiery vermilion; or orange scarlet, a veritable "hedge of fire," one of the most profuse bloomers, rivaling the Countess of Lonsdale; a splendid flower on long, erect stems high above the foliage; compact, vigorous bush. Vulcan is the ideal hedge Dahlia-and as a cut flower outlasts other Dahlias. Try it.

Weisse Dame-A valuable new white of splendid form; large, full, petals curved and twisted; one of the best and most free-blooming of white cactus Dahliss; its great wealth of perfect flowers are borne erect on long wirey stems; compact bush.

\section{CULTURE}

Dahlias will grow to perfection in any good garden soil, preferably one that contains a little sand. Plant as soon as the frost is gone and the ground warm, cutting the tuber to a single strong eye, and placing it on its side at a depth of about 6 inches, in ground that has been previously well cultivated. An excellent way to start Dahlias is to sprout the tuber in a green house and set out the rooted plants. These are generally believed to give more and better flowers, but is more trouble than planting the bulbs. Rows should be four feet apart, plants 18 inches to 3 feet apart in the row, depending on whether planted for a hedge or for specimen plants. Cultivate thoroughly until ready to bloom, then deep tillage must cease and only the surface be lightly stirred, as deep cultivation at this time is fatal to blooming.

If you use commercial fertilizer, do not apply until the plant starts growth, then work it into the top soil, 5 or 6 inches from the plant. Bone meal is an excellent fertilizer for Dahlias but must be applied early, as it is slow in action. When the plant is well up, say 6 to 10 inehes, pinch off the top, leaving 2 or 3 joints. This will cause it to branch out into a more sturdy, bushy growth. Water freely. 


\section{New Paeony Flowered Dahlias}

A complete list of the best varieties, including the most recent introductions.

$\mathbf{T}$ HIS newest type of Dahlia, originating in Holland, comes to us with the endorsement of all Europe.

The blossoms are semi-double of enormous size, and the coloring is most brilliant and beautiful. They come in several pleasing forms, generally with 3 to 5 rows of petals, which are long and broad, sometimes being beautifully curled and twisted.

Peony Dahlias bloom more freely than any other class, are very vigorous, growing to a height of 5 to 6 feet, with their flowers on long stems above a) glowing to a helght

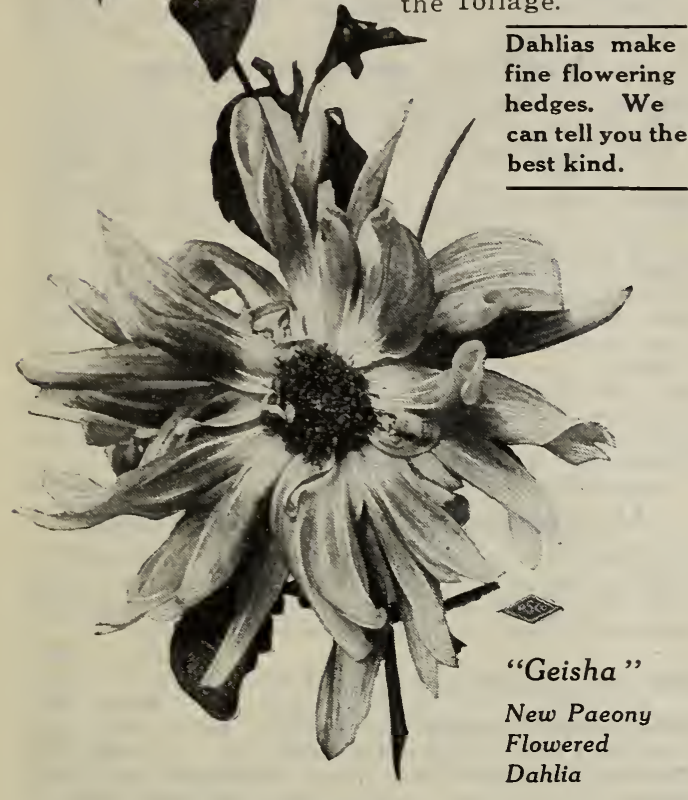

\section{Geisha}

This is the most remarkable and distinctive Dahlia ever grown, and while belonging to the "paeony" section, is in a class of its own; the color is unique, entirely apart from other Dahlias, having a rich, bright golden yellow ground color near center; suffused and heavily marked with clear bright red, shading toward points of petals into the clear yellow of the ground color; a beautiful deep golden center, adds to the harmony of the color scheme which is the most striking and brilliant ever seen in a Dahlia. The immense flowers often attain a width of 10 to 12 inches, and the massive petals, more than in any other paeony type, are twisted and curled in the most fantastic manner. Geisha is a sure grower and free bloomer even in the driest weather, but is a shy reproducer and very scarce.

Eaoh, $75 c$

\section{Giant Edelweiss}

This new type of Dahlia has true cactus petals of enormous length, curving inward at the tips; color a pure glistening velvety white, of great substance; the center is a brilliant golden sellow, forming a most striking contrast, producing a perfect duplicate of the famous Edelweiss of the Alps, on a gigantic scale, hence its name.

For vigor of growth, free blooming and perfection of individual flowers, we have never seen its equal. Planted in the field without irrigation in the dryest season, "Giant Edelweiss" was a mass of bloom, flowers from 6 to 8 inches across on long stems borne high above the compact bush, which grows 4 to 5 feet.

Strong flowering roots or plants in season, each $75 \mathrm{c}$

\section{Germania}

A rich, dark, velvety wine color with a suffusion of golden-yellow toward the edges of petals. Germania is free from the purplish tint that spoils other reds.

Plants or tubers.

Each, 35c; 3 for $\$ 1.00$

\section{Queen Wilhelmina}

Large pure white, central petals beautifully twisted and curled; very vigorous and free flowering; one of the finest garden Dahlias. Plants or tubers.

Each, 35c; 3 for $\$ 1.00$

\section{Glory of Groenekan}

Extra large flowers of finest form. Color a splen did golden orange. Strong grower; free-flowering. Plants or tubers. Each, 35c; 3 for $\$ 1.00$

\section{P. W. Janssen}

A magnificent Dahlia of splendid form and dis tinctive coloring, being a lovely shade of old rose, marked and suffused with deep, rich golden yellow, a rare and beautiful combination.

Bush grows to a height of 5 or 6 feet, is very vigorous and blooms freely. The giant flowers are borne high above the foliage, on long, strong stems. Eaoh, 40c postpaid; doz., $\$ 4.00$

\section{Philadelphia}

This new Giant Dahlia belongs to the same type as Giant Edelweiss. Color is carmine rose, passing to a soft blush white, center bright yellow; showing stems above the foliage, 4 to 5 feet.

Roots or plants in season, each $50 c$

\section{TRIAL \\ - Entire Collection Well Rooted Plants, Prepaid to any address, \$6.00.}

We cannot furnish bulbs of these varieties, but recommend rooted plants as giving even better results than tubers.

King Leopold-Cream yellow to white, Large, long stems, good.

Ia Riante-Deep pink flowers, long stems, good keepers, distinct garden variety of great value.

Each, 35c

Mannheim-Soft orange, fine form.6 ft., Each, 50c Merveille-Orange yellow, of great beauty. $41 / 2 \mathrm{lt}$, Each, $50 \mathrm{c}$

Paul Kruger-Large white, shaded red, bright attractive. $3 \mathrm{ft}$., Each, 35c Queen Alexandra-Sulphur white, fine 4 ft., 75c Andrew Carnegio-Salmon pink, shaded bronze, extra large.
Bertha Von Suttner-Salmon pink, shaded yellow, erect, elegant form. Each, 50

Baron G. de Grancey-Creamy white, long stems, good habit. Dr. K. W. Van Ghorkom-White shaded rose, free blooming. Each, $35 \mathrm{c}$ Glory of Baarn-Soft pink, erect, giant size, fully double. H. Hornsveld-Enormous soft salmon pink flowers Hugo de Vries-Brownish orange, open form

King Edward-Large purple crimson, fine. 


\section{FINEST CACTUS DAHLIAS}

From comparative tests in the field we have selected the following as being the best of their types and color. This list contains many of the new Dahlias as well as the best of the older ones:

In lots of one dozen or more deduct 25 cents per dozen from the single price.

\section{White}

Fairy-Beautiful clear white, narrow petals, fine form; one of the best; try it. Each, 25c Florence M. Stredwick-A grand new white; large, fine form.
Schwan-'The giant. blooms of a pure glistening white with their narrow, twisted petals have a beauty and elegance not approached by any other variety. Blooms early. Each, 35c

Lawine-Fine large white, faint blush tint, erect, free-flowering; extra good.

Each, 35c

\section{Red}

Berlichengen-New, deep crimson-carmine; brighter at tips; of the finest form and substance; a true cactus type of rare beauty; very floriferous. Each, 250 Burbank-Deep rich cardinal red, of finest form and substance, full and free blooming; best of its color.

Matchless-Dark rich crimson.

Each, $25 c$

Progenitor-Bright carmine, fringed petals, new variety of great beauty. Each, $20 \mathrm{c}^{\circ}$

Uncle Tom-Deep velvety crimson; almost black: fine form, full and attractive. Each, 20c

Roland Von Berlin-A fine scarlet of great brilliancy, flowers full and erect; long stems: one of the best.

Each, 35c

Rother-Dark rich crimson, very early and free flowering, of vigorous, erect habit; bush rather dwarf; flowers of the largest size; perfect cactus type.

Signal-Brilliant crimson-scarlet; height 24 inches; flowers large, of fine form; free-blooming.

\section{Pink}

Brittania-Beautiful salmon-pink.

Each, 35c

Each, $25 c$ ferous.

Frau color the same lovely shade of pink as the LaFrance rose; center delicate flesh; erect, free blonmer; very desirable. Pink Pearl-Deep rich pink; fine form. Each, 20c Kriemhilde-Blush-pink; a nrize winner; one of the finest new Dahlias.

Each, 20c
Helene-Delicate, clear pink, with rich creamy center, a beautiful flower on very long stems and the greatest bloomer of all. $\quad$ Each, 35c

Mrs. Stranock Gaskill-A delicate shade of exquisite pink; large, finely petaled; a rare novelty of great beauty.

\section{Yellow and Shades}

Capstan-Orange-scarlet and apricot; one of the finest for cut flowers; dwarf habit, free-bloomer, with large, perfect flowers on long, stiff stems.

Each, 15c aster Carl-Bright amber, of giant size and perfect form, immense petals, gracefully curved; free-blooming, distinctive.

Prof. Zacharis-Beautiful clear bright yelluw; profuse bloomer; good garden sort. $\quad$ Each, 25c Miss Dorothy oliver-Pale primrose yellow; long narrow petals; fine form; beautiful and attractive. $\quad$ Each, 35c

Stern-Odd and beautiful; stàr shaped; puro lemunyellow flower; vigorous; good for garden or cut flowers.
Prince of Yellows-Splendid lemon-yellow, ireeblooming, finely formed flower. Each, 20c

\section{Variegated and Shaded}

Aschenbrodel-Urange pink, distinct coloring; of great beauty of form, vigorous, free-flowering; one of the fiest ever produced. Each, 25c Antelope-Rich yellow; bronze red shading.

Each 25c

Papagei-Yellow and rosy red, lemon tips.

Reliable-A blending of yellow, brick red and salmon; truly a grand flower.

Effective-Chamois rose, yellow shadings. Each, 25c Comet-Extra large, silvery rose, marked crimson, a rery free bloomer, of good habit. Each, 25c Aurora-Considered the grandest Dahlia ever grown. We are inclined to this belief after personal observation during the past season. Color almost indescribable, shading through tints of pink, amber, rose and cream; a model flower of perfect form, and splendid habit of growth.

Iach, 35c

\section{Decorative, Show and Fancy Dahlias}

Dreer's White-A magnificent white, of great purity, long stems.

Each, 35c

Dr. Gates-Beautiful shell-pink; good for cut flowers.

Each, 20c

Jeanne Charmet-A dainty exquisite pink, margined pale yellow, shading to pure white at center, large, fine, full form, erect, long stems, one of the best of the new decoratives. Price, each, 35c

Kaiserin Augusta Victoria-Magnificent white flowers, of immense size and perfect form, borne erect on long stems high above foliage, blooms freely until cut down by frost, invaluable for landscape or large plantings. $\quad$ Price, each, 35c

Lavender Queen-Clear, soft lavender; petals deeply serrated. Each, $15 \mathrm{c}$

Mrs. Winters-Snow white, large beautiful form.

Each, 20c

Miss Frances Fell-Decorative; white, lilac shading.

\section{Quilled Varieties}

A. D. Livoni-This grand old variety still remains the best pink of its type.

Each, 15c

Grand Duke Alexis-Finest large white. Each, 15c

Lucy Fawcett-Sulphur-yellow, flaked crimson.

Each, 15c

Thos. Pendred-Finest and largest of the pure yellows, a rich soft shade of golden yellow, perfect form, blooms freely and continuously even in dryest weather.
Mme. A. Lumiere-Pure white with violet red points, good.

Each, 35

Mrs. Roosevelt-A beautiful, delicate pink, of immense size, fine stems, perfect form, large and double, superb.

Navajo-Rich, velvety red; splendid sort. Each, 20c Opal Queen-A rare, new color; the same as the stone of that name.

Each, 20c

Perle D'Or-Large, pure white, free bloomer, erect, edges of petals split giving distinct appearance.

Each, 20c

Sylvia-Splendid pink; floriferous; keeps well.

Each, 15c

Souvenir de Gustave Doazon-(Decorative.) The largest Dahlia to date; often growing 9 inches in diameter; constant bloomer, magnificent rich scarlet color; the greatest of all Dahlias. Each, $25 \mathrm{c}$

\section{Pom-Pons}

These are pretty little globe shaped flowers, on long stems, high above the dwarf foliage, fine for border, keep well when cut.

Catherine-Purest yellow; large Each, 20c Darkest of All-Darkest pom-pon; perfect flowers Each, 20c

Nerissa-Soft pink, silvery tint; a beautiful new color. 


\section{GLADIOLI}

TIF newer types are of immense size and exquisite coloring, their grace and attractiveness now commanding the attention they have so long deserved. This season we offer a splendid novelty in the New Giant Ruffled Gladiolus "Glory," a marvelous flower of this new race which is an American introduction of the utmost importance.

CULTURE.-Gladioli may be planted as early as the ground can be worked or as late as June. A sunny situation is preferred. Plant to a depth of 3 to 6 inches, depending on the size of bulb. Largest lulbs are not always best, as some varieties do not produce large bulbs. Any garden soil will give satisfactory results, but if well enriched, cultivated and freely watered when buds first show, Gladioli will amply repay you for this additional care. If cut when the first bud opens and put in water, the flowers will open perfectly, keep for many days, and the coloring is richer and more delicate than if left on the plant.

\section{New Giant Ruffled Gladioli}

A distinct novelty of genuine merit.

Ruffled Gladioli have broad, expanded flowers, paired and faced the same way, borne on strong stalks, $3 \frac{1 / 2}{\text { feet high, }}$ from 4 to 8 flowers open at the same time; petals are exquisitely ruffled and fluted, giving the flower a refined, graceful appearanice. The originator has many varieties in all colors and shades that will be offered as rapidly as stock can be produced. One selection will be given to commerce in 1911 and has been named.

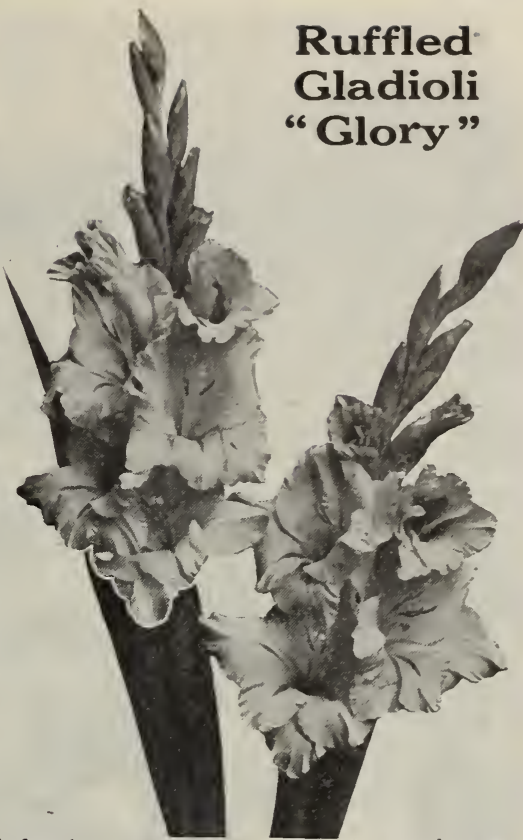

Gladiolus Kunderd1-“GLORY." Color a delicate cream pink tint with an attractive crimson stripe in the center of each lower petal. The shade is new and the flower is indeed a glorious beauty. There are but few bulbs offered this season and as the introductory price is very low, you should order now and be one of the fortunate few who will secure this great novelty for trial. Price, each, 25c; doz., $\$ 2.50$

\section{FIVE Beautiful and Distinct Gladioli 5 Bulbs, One Each, Post Paid \$1.00}

DAWN-An elegant rose-colored flower with new Gladiolus.

Price, Postpaid, ea., 25c.; doz., $\$ 2.50$

CONTRAST-Intense scarlet with pure white center; one of the grandest, most attractive new flowers.

\section{Price, Postpaid, ea., 30c.; doz., \$3.25}

12 Select Gladioli,

AMERICA-Exquisite shade of flesh pink tinted lavender. The most popular gladiolus. ATTRACTION-Deep crimson, white center AUGUSTA-Lovely pure white; blue anthers. BRINCIIFYINSS-Rich vermillion, shading to scarlet.

CANARY BIRD-A pleasing bright yellow.

RARIFQUIN-White-striped and suffused with rich dark crimson.

I. S. HgNDRICKSIN-Large, beautiful flowers, mottled, white and pink: variable. Price, postpaid, each 15c.; entire collection, 12 varieties, \$1.50.

\section{Mixed Gladioli}

DIAMOND MIXTURF-Select named varieties with choicest Childsi Hybrids.

Doz., \$1.00; 100, $\$ 5.00$

GIADIOII CBIIDSI-Of grand size and color, very showy, containing a large per cent of red and dark shades. Doz., 75c.; 100, $\$ 4.00$

GIADIOII, FINI MIXID-This mixture will produce a large variety of fine flowers unequalled for the price. Doz.. 50c.: 100, \$3.00
WIID ROSF-Bright rose or blush tint, of rare beauty; large, free-flowering; forces well. $\quad$ Price, ea., 25c.; doz., $\$ 2.50$

BIUIJAY-The only true blue Gladioli; a i'ark indigo shade; very popular.

Price, Postpaid, ea., 20c.: doz., $\$ 2.00$ ANCAE-A splendid large white flower with but faint markings. One of the b'st.

Price, each, 20c.; doz., \$2.00

\section{Best of Their Color}

KIONDYKE-Light yellow, crimson maroon blotch.

MRS. FRANCIS KING-A pleasing light scarlet; fine for forcing.

OCTAROON-Beautiful salmon pink.

SUNIIGIT-Iight crimson, canary throat mottled velvety maroon.

SUPצRB-Enormous pink, flaked and striped salmon.

GIADIOII, GROFF'S RYBRIDS-A mixture of Hybrids of all sorts, giving in one bed the greatest range of colors and variations.

Doz., 50c.; 100, $\$ 4.00$

GIADIOII IrMOINII-Mostly light shades, odd and fantastic markings. Brilliant and showy;

Doz., 50c.; 100, $\$ 3.00$

\section{Caladiums}

Esculentum-(Elephant's Ear) Grand tropical looking plant. A favorite for specimens on the lawn, or for bordering large sub-tropical groups. In deep, rich soil, if freely watered, they produce enormous leaves, frequently four feet long by three feet wide. Plant in the spring. Height, 4 to 5 feet.

Each, 25c: doz.. \$2.00

\section{Tritoma}

Pfitzeri

Everblooming Flame Flower or Red Hot Poker This new sort is of a rich orange scarlet, blooming from mid-summer to latest fall; spikes 3 to 4 feet high; one of the very best of this useful class, which is hardy with slight protection, but winter best if lifted and stored in sand. These hardy perennials are unsurpassed as border plants or for mass effects. effects.

Strong flowering roots $25 \mathrm{c}$; doz. $\$ 2.50$, prepaid 


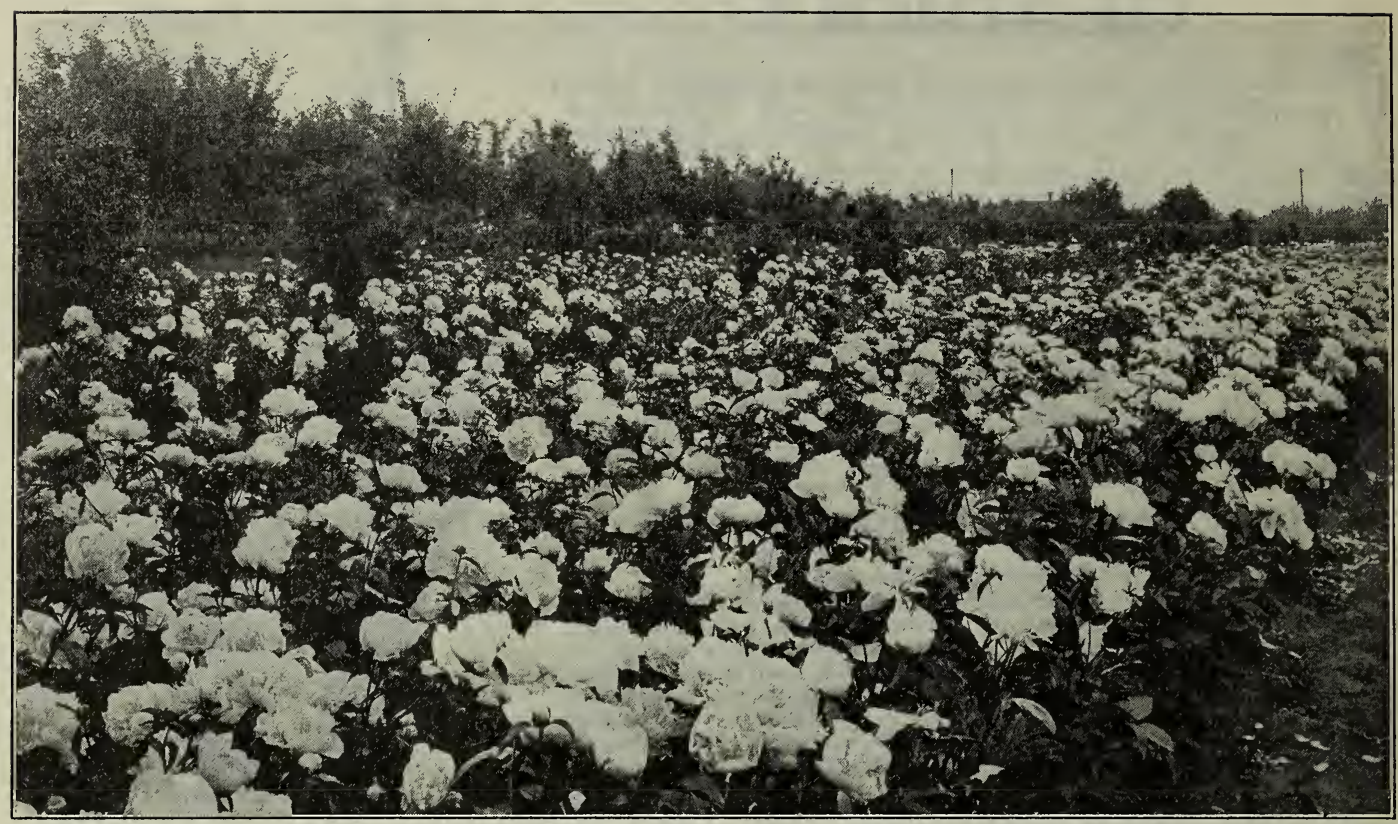

Nursery near Portland where.. our "Diamond Quality" Paeonies are grown.

\section{Paeonies, Double Herbaceous}

TFF development and increase in popularity of the Paeony has been unparalleled among flowers, and the profusion and duration of bloom, combined with handsome, massive foliage, accommodating habit, and easy culture, render them one of the most popular, hardy plants grown for lawn and garden decoration.

NEW-BARONESS SCHROEDER.

(Kelway)-We offer true stock of this rare Paeony, the most beautiful and desirable of English introductions.

Color in bud is a lovely, delicate flesh pink, bleaching to white when fully expanded, extra large massive flowers; true stock is scarce and we can supply but a limited number of field grown roots, 2 to 3 shoots. Price, each, $\$ 2.50$

Festiva Maxima-This superb variety is easily the most popular and valuable Paeony. Its flowers, of rare beauty and great size, are perfectly double, pure white, tipped or flaked with a small crimson spot at center; petals fine as summer silk; finest white in cultivation; strong roots. Price, each, 75c. Iarge specimen plants, $\$ 2.00$

Officinalis Rubra-Flowers of a bright scarlet crimson; quite double and globular; very early, rare and fine.

Price $30 \mathrm{c}$

Officinalis Alba-Blooms with Officinalis Rubra flowers, large and handsome. When Alba first opens it is light pink, fading to white as flowers get older. Price 30c

Golden Harvest-Nearest approach to yellow; shows some pink while in bud, but as soon as it opens, turns to a creamy yellow, with a few red tips; a tine free bloomer and a grand flower; mid-season.

Price 60c

Mad. de Verneville-Broad outside petals, sulphur white, with center rosy white, sometimes edged carmine, and beautifully imbricated; an exceptionally fine full flower, with the sweet fragrance of the rose. One of the earliest.

Price 60c

OFFICIANAIIS ROSEA-Beautiful bright pink globular flowers, blooms with officianalis alba and Rubra. These splendid early bloomers produce fine flowers for Decoration Day. Price, 30c
FIORAI TREASURE-Lovely salmon pink tint, greenish heart, large full flower, light green foliage; a free bloomer and a fine cut green foliage; a free bloomer and a fine cut
flower.

DELACHEI-Large full flower of a deep rich crimson, purplish tone; a free blooming

thrifty grower, very fragrant; meduim to
late. late.

SOUVENIR DE I'EXPOSITION-Large full flower of a lovely light cherry red. Price, 60c

COURONNE D'OR-A superb white flower of immense size, reflects yellow, center petals bordered carmine, a perfect flower of great beauty, very fragrant, free blooming and vigorous; late.

MAGNIFICA - Truly a magnificent peony; color a beautiful rich pink; a thrifty, free blooming and desirable kind. Price, 40c

QUFENS PFRTECTION-One of the finest of the creamy flesh whites, large, full and attractive.

\section{Paeony Moutan}

\section{(Tree Paeony).}

Grows about four feet high, forming a small, tree-shaped shrub. When this plant becomes well established and is covered with dozens of massive blooms, it presents a magnificent display. We have Crimson, Pink, Scarlet, Rose and Variegated.

Strong Imported Roots, from January to May, by express at buyer's expense (too heavy to mail).

rach, 75c

Preontes are always free from disease and insects do not bother them. They are hardy, thrifty growers, bloom freely, and nothing will add more to the beauty and attractiveness of a lawn. 


\section{Yucca}

Spanish Bayonet or Adam's Needle-Has a fine appearance; the stems grow two to three feet above the ground; covered with large, nell-shaped nowers on laterals, forming a perfect pyramid; valuable for rockwork.

Filamentosa-Thread leaved, creamy white; July.

Plants, 2 feet, each, $75 \mathrm{c}$ to $\$ 1.00$

\section{Bleeding Heart}

Spectabilis-One of the most ornamental of hardy spring flowering plants, with elegant, green foliage and long, drooping racemes of heart-shaped flowers. This is deemed one of the finest of all hardy garden plants.

Strong Roots,

Each, 30c, postpaid

\section{New White Bleeding Heart}

Spectabilis Alba-A splendid novelty for conservatory or cool greenhouse. If planted outside, must be placed in a sheltered position. A pure white, free-blooming, beautiful variety of great value. We have grown this in the open with splendid results. Try it.

Strong Roots Each, 50c; postpaid ST. JOENS WORT-Clump

Fypericum Moserianum.

Low growing with yellow blooms; a drougth resister. July and August. 50c.

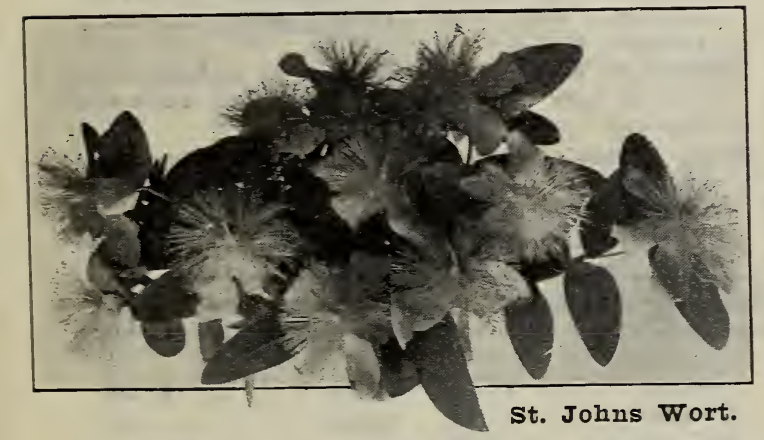

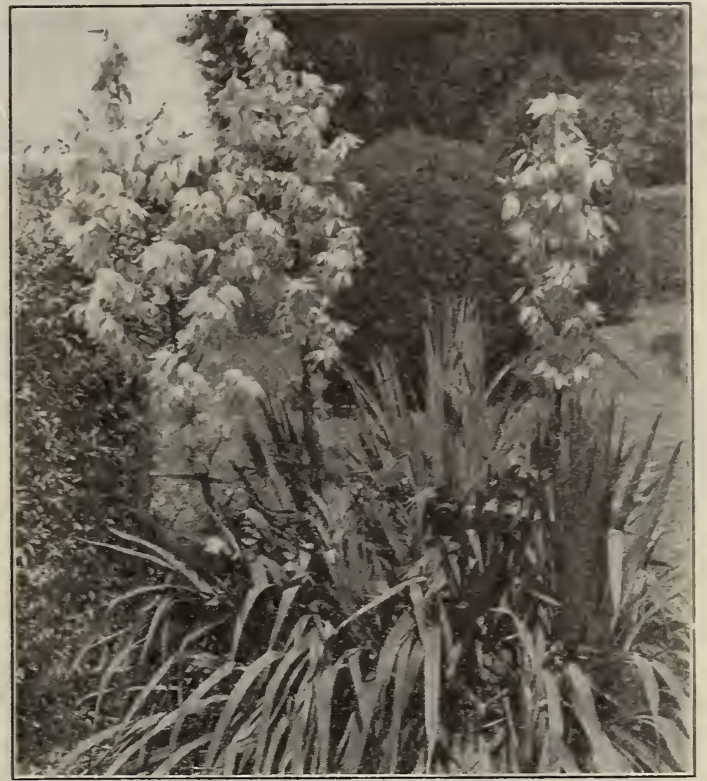

\section{Pampas Grass}

A noble ornamental grass, easily grown, producing long, pointed leares and majestic, sil. very white plumes, which are very valuable for winter decoration; grows 6 to 8 feet high. Strong roots, each, $60 \mathrm{c}$ to $75 \mathrm{c}$ Large specimen plants, $\$ 2.00$ to $\$ 5.00$

\section{CEIMSON FOUNTAIN GRASS.}

Foliage and stems deep bronzy red, with long tassell-like inflorescence of rich crimson. Cut this while in the sheath, drying in a cool place and it will develop perfectly. The most beautiful and useful of the ornamental grasses. Height 6 feet. Price, nice plants, each, 25c; dozen, $\$ 2.50$. Iarge plants, each, $50 \mathrm{c}$.

\section{Water Lilies}

These beautiful and interesting plants can be easily grown in tubs made by cutting a barrel in half and setting one or both halves deep in the ground, to within a few inches of the top. Put in good loam soil, with one-third old manure, or better still is the soil from a swamp or lowland, using one-third of old well-rotted manure; cover soil with a layer of sand one to two inches deep, allowing for a depth of six inches of water.

Water Lilies like a mild temperature, and still water, and will not succeed where a fountain is playing or where there is a cold or strong inflow.

เvymphae-Hardy -white.

Single roots, 35c, postpaid Large roots, $75 \mathrm{c}$ to $\$ 1.50$ prepaid

Nymphae-Hardy yellow; fragrant.

Single roots, 50c, prepaid

Large roots, $\$ 1.50$, prepaid

\section{Parrots Feathers}

Produces long trailing sprays of lovely green, finely cut foliage set in symmetrical whorls; plant in a water tight vase or hanking basliet, keeping water standing over the surface. A beautiful, thrifty growing, ha:dy plant. Try it. Good roots, each, 25c; doz., $\$ 2.50$.

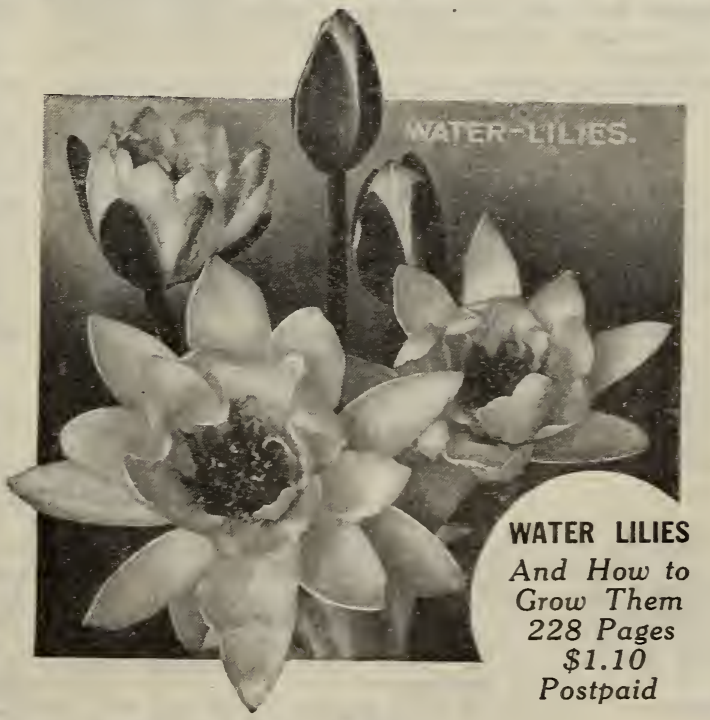




\section{Mastodon Pansies}

FOR Jears the Steele Pansy Gardens have grown our Giant Pansies and co-operated in securIng the finest strains from the world's most celebrated growers. These have been carefully reselected and bred up to their present surpassing excellence, and for giant size, substance, form and coloring we have never seen Pansles to compare with them. Named varieties and special strains are grown separately and the seed collected by hand and carefully blended into what we believe to be the finest mixture ever offered.

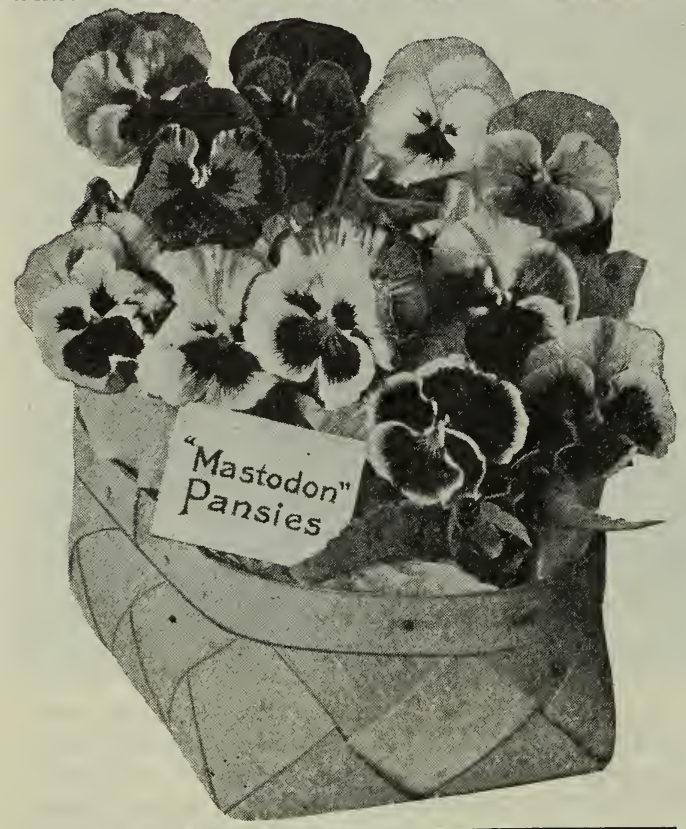

MASTODON PANSY SEED

We offer a limited amount of this hand selected seed, DIAMOND MIXED.

Per pkt., 25 cents. Large Trade pkt., $\$ 100$

\section{"Mastodon Pansies" in Bloom}

From March until June we offer our famous "Mastodon" Pansy plants in full bloom-none finer in the world. Put up one dozen in a basket.

Price, 60c to $\$ 1.00$ per basket by express, buyer to pay charges. You will not be disappointed in these.

\section{Giant Pansies}

NEW GIANT PANSIES-Qur Giant Plants are in a class of their own and cannot be compared to any other Giant Pansies, no matter where grown. We know that their equal is not produced in this or any other country. A trial basket will con. vince'you. They are the best value ever offered in a bedding plant.

Each, 5c; per dozen, 50c; by mail, $75 \mathrm{c}$ dozen.

\section{Sweet Violets}

Price, each, $15 \mathrm{c}$; 6 sorts, $75 \mathrm{c}$.

Alaska-A grand sort, well adapted to garden culture; enormous double flowers of a deep blue black color and powerful fragrance.

Lady Hume Campbell-Large double flowers of : beautiful light blue color; very free-blooming and exquisitely fragrant.

California-Very showy and beautiful flowers of enormous size, deep violet blue; deliciously fragrant; single.

Princess of Wales-Flowers single, of gigantic size; color a very rich shade of blue, and extremely fragrant.

Marie Louise-A constant bloomer, producing great quantities of large, double flowers, lovely deop violet purple.

Swanley White-The finest and best double white violet in cultivation.

\section{Popular Bedding Plants}

During the months of April and May we have thousands of the following hardy bedding plants, price per dozen by express at buyer's expense:
Alyssum ...... .35
Asters ........... .25

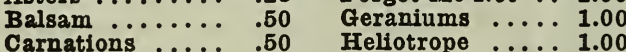
Daisies ...... \$.50
Forget-Me-Not $\ldots 1.00$
Lobelia ......\$ .35
Marigold ....... .50
Mignonette ..... .50
Petunia ....... .50
Phlox .......\$ .50
Cosmos .........35
Hollyhock ...... 1.00
Salvia $\ldots \ldots \ldots . .50$
Pansies ...... .50 Verbena $\ldots \ldots \ldots . .50$

For description of these flowers, see Flower Seed Department. If wanted by mail, add 25c per dozen for postage. and if it does not require this amount. we will put in extra plants.

\section{Hardy Perennial Garden Plants}

\section{Price, each, 15c; 6 sorts, 75c}

English Primroses-Finest sorts, from pure pellow to deepest crimson-maroon; early, low-growing, fragrant.

Gaillardia Grandiflora-Splendid large flowers; combination coloring of yellow, brown, crimson, orange; height 2 feet; bloom until frost; fine for cut flowers; hardy everywhere.

Coreopsis, Golden Sunbeams-Beautiful golden-yellow flowers on long stems; always in bloom; fine for cutting.

Campanula-New Double White-A dainty and beautiful flower, 2 to $2 \frac{1}{2}$ feet high, bearing spikes of large snow white, prettily formed, fully double blossoms. Pinch off the old flowers and the plant will bloom continuously. One of the best border or bedding plants ever of fered.

Hollyhocks-Old favorites now in great demand.

Double and Single-White to deep maroon; extra fine strains.

Poppy, Iceland-Beautiful dwarf-growing, continual producer of lovely cup-shaped flowers; yellow, orange and white.

Helianthus, Solell D'Or-Graceful golden yellow flowers; petals quilled; always in bloom.

Rudbeckia, Golden Glow-Bears in greatest profusion immense, double blooms, large as Dahlias, of the brightest golden yellow; hardy everywhere.

Shasta Daisy, Alaska-This new "Shasta" is covered with immense fluffy white blooms, with golden eyes, from July until late fall; long stems; fine for cutting; one of our best hardy border plants.

Helianthus Sparsifolia-Superb new single sunflower of striking beauty; blooms late in the season. A real gem among hardy plants. We especially urge you to give this a trial.

Poppy, Oriental-Immense rich orange scarlet flowers.

\section{Perennial Phlox}

Hardy as an oak, increasing in beauty each year, few things are as beautiful and satisfactory. The marvelous new colors, beautiful foliage and casy culture, make this choice flower one of the most desirWe offer the following fine collection which we have grown:

Beranger ...... White with pink eye; dwarf.

Bacchante ..... Rose with crimson eye; tall.

Clara Benz .... Rose with deeper eye; dwarf.

Caran d'Ache...Red, rose shading, white oye, medium.

Eclaireur ...... Rose with lighter halo; tall. Price, Strong Flowering Roots, each, 15c; doz., $\$ 1.50$
La Vague ...... Pure mauve, red eye; medium.

Pacha ........ Deep pink with red and carmine purple eye; dwarf.

R. P. Struthers. . Rose carmine, red eye; tall.

Miss Iingard ... Fine early white; tall.

Geo. A. Strohlein. Bright scarlet, red eye; medium. 


\section{GERANIUMS}

TE popular demand for Geraniums has encouraged us to provide an ideal collection of superb new varieties which we know will be appreciated by our customers. To repeat the words of a famous grower, "We believe in Geraniums." They grow beautifully through. out the entire year, making cheery house plants, and are our finest hardy bed and border plants. No other flower has a wider range of usefulness.

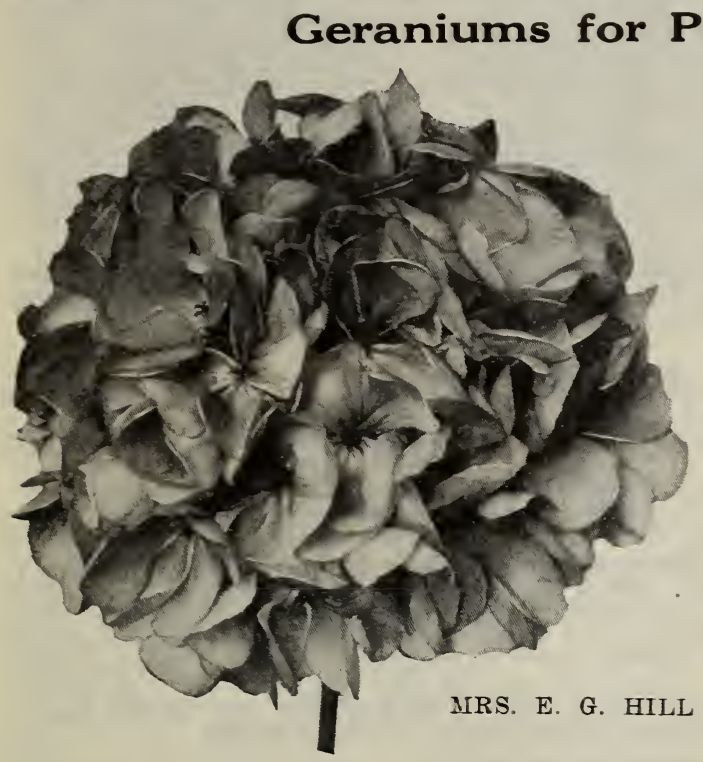

and Bedding

SIX FINE SINGIE VARIETIES.

Price, postpaid, 10c each; set of 6 sorts, $60 \mathrm{c}$.

GERTRUDE PFARSON-Flowers bright pink, upper petals shaded to white.

JACQUERIE-Rich, vivid crimson; immense trusses.

JAMIDS KEIWAY-Brilliant scarlet, of the most dazzling shade; very large trusses and florets.

MRS. J. M. GARR-Trusses large and of perfect form; color pure snowy white.

MRS. A. BIANC-Light salmon, blended with darker shades: center and edge of petals pure white; extra fine.

SAM SIOAND-An extra fine velvety crimson maroon carrying immense trusses. SIX FINE DOUBLF VARIFTIES.

Price, postpaid, $10 \mathrm{c}$ each; set of 6 sorts, $60 \mathrm{c}$. FRANCIS PERKINS-The finest pure pink variety we know of.

JOHN DOYIE-Very large and full trusses of double bright, velvety scarlet flowers.

IA FAVORITE-Trusses very large; flowers pure snow white.

MME. JAUIIN-A truss of grand size, delicate pink, bordered with pure white.

S. A. NUTT-The best of the rich, dark crimson varieties: trusses massive.

THOS. MIFHAN-Rich various rose color, upper petals marked with orange.

\section{Rare New Single Geraniums}

Price, 15 cents each; set of 10 Sorts, \$1.25.

CABRIEI MONTOYA-A most distinct and striking shade of reddish purple; large, round, full flowers; immense trusses; free flowering; strong, robust grower and grand habit.

EAII CAINE-Brilliant orange scarlet, suffused rose; a unique and charming self color, flower of giant size; grows well, is free blooming and desirable either as bedding or pot plants; one of the finest Geraniums ever grown.

MAXINF RAVOIFVSKI-Odd shade of orange red; very distinctive, splendid bedder, vigorous, handsome, a dependable sort.

MMr. MOSNAY - Beautiful shade of Geranium lake; upper petals shaded violet to a white center; flowers freely produced in enormous trusses; clean, strong, robust, healthy grower.

MAD. CHAPOTAN-Delicate light pink; large flowers of good habit, nice foliage; specially desirable as a pot plant.

PAMrLA-Large, pure white center with a shading through a maculated effect to a broad distinct outer margin of crimson lake; flowers large and round; enormous trusses, freely produced.

SNOWDEOP-Pure snow white; enormous trusses; perfectly formed flowers, held well above the beautiful foliage.

THEODORE DE WYZEWA-A bright, cheerful clear shade of rich lilac rose; large white blotch at the base of upper petals; flowers and trusses all that could be desired, and abundantly produced.

TIFrIN-One of the freest blooming single scarlet bedding varieties; rich, glowing scarlet, crimson maroon shading on upper petals.

VICTOR GROSSIT-Bright rich shade of apricot salmon; valuable acquisition to a color in which good varieties are scarce; blooming freely; strong, healthy constitution and splendid habit.

\section{plant. \\ 10 Rare New Double Geraniums \\ Price, 15 cents each; set of 10 Sorts, \$1.25.}

IDMOND BIANC-Semi-double; deep carmine, red tinged violet, with large white eye. We have found this to be one of the finest new sorts out.

DR. PEIIIIPE TISSIn-Robust grower; large trusses borne on long stems; light crimson, shaded through magenta to grand white center. Beautiful and striking.

FIEv "I BIANC-Color pure white; very large, handsome, rich green foliage, zoned with dark green; growth dwarf, vigorous and compact.

GFNPRAI SAUSSIFR-Exquisite shade of carmine, shading to white center; large trusses.

JAMAIQUंग. Grand, large trusses of enormous flowers of rich cherry red.

MMrs. BARNIY. A splendid deep pure pink, of a lively shade and grand habit of growth; dwarf and branching.
M. ANATOIF BOSIIrUR. A most beautiful shade of deep rose pink, rivaling in beauty and freshness the color of the Paul Neyron rose, a color that has been more admired than that of any Geranium we have on our place.

MMr. CHARROTTr. Clear, distinct rosy salmon, shading lighter toward the outer edges-a combination that is pleasing and attractive.

MME. IANDRY. A distinct salmon pink, with a slight shading of scarlet; habit semidwarf, vigorous; broad, heavy, deep zoned foliage.

ORNIIIA. A magnificent new variety, which we are confident will meet every requirement of a semi-double scarlet Geranium, either as a pot plant or a bedder. The color is so intense scarlet as to dazzle the eye. 


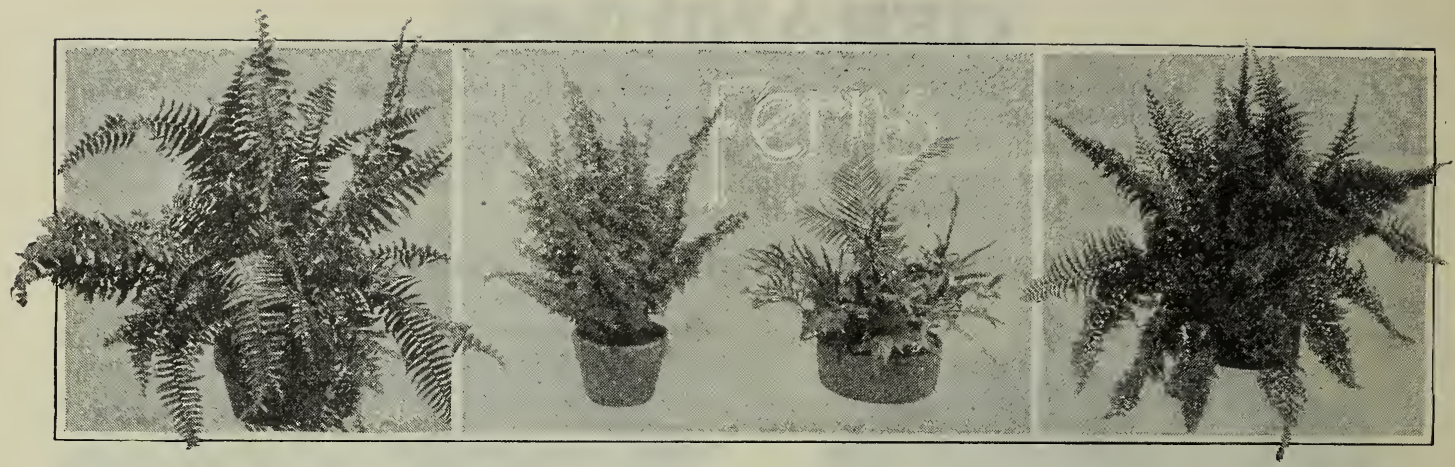

W' older sorts. All plants are in fine growing condition, and well rooted. Florists wishing stock of the new varieties write for prices.

\section{Nephrolepis or Boston Ferns}

N. Amerpohli- This charming "Lace Fern" is so finely "crested" as to have a fluffy lace-like appearance that makes it the most beautiful and attractive "sport" that has yet been developed from the Boston Fern. The growth is rather dwarf and bushy, making an ideal plant for house or table decoration. Price from 4-inch pots, $60 \mathrm{c}$.

N. Scholzeli-The crested Scott Fern. Makes a dense, compact growth; is finely crested and of dwarf habit; stands erect with gracefully arching fronds making beautiful specimens in small as well as large plants. from 4-inch pots, fine well-rooted plants, 600 postpaid.

Boston Fern-This is the original and well known type of "Sword Fern," so popular as a hardy house plant. Nice plants, each, 20c; large plants, each, $35 \mathrm{c}$ to $50 \mathrm{c}$; specimen plants, $\$ 1.50$ to $\$ 3.00$.
Scott Fern (Nephrolepis scottii)-Identical with the original Boston type, but is dwarfer with a more compact and bushy habit of growth. Price, from 4-inch pots, 60c postpaid.

Ostrich Plume Fern (Trephrolepis Whitmant) -One of the most wonderful and beautiful introductions of the present age; this new sort is a sport from the well known Boston Fern; has a beautiful feathery appearance, and is one of the grandest of decorative house plants. rice plants, 200 to 350 each; specimen plants, $\$ 2.50$ to $\$ 3.00$.

Superbissima-The most unique and distinctive fern. Color a deep rich green, ve:dense and erect habit; foliage finely cut and crested; succeeds splendidly under a!most every condition and is a very desirable table decoration. Price from 4-inch pots, nice plants, $60 \mathrm{c}$.

\section{New and Popular Ferns}

Maiden Hair (Adiantum Croweanum)-This is the hardy Maiden Hair Fern so valuable to florists for cutting, and must not be confused with the older sorts that cannot be successfully handled; this fern grows freely under almost any condition inside, and if you have not been successful with "Maiden hair" ferns as a pot plant, try this one; it is a sure grower.

Good plants from 4-inch pots, $\$ 1.00$ postpaid. Asparagus Sprengeril (Emerald Feather)-Handsome and valuable evergreen trailing plant for the house or conservatory; its beautiful sprays of lovely green, feathery foliage can be cut freely. Nice plants, each, 20c; large plants, $35 \mathrm{c}$ to $50 \mathrm{c}$.

Ostrich Plume Fern-One of the most wonderful and beautiful introductions of the present age; this new sort is a sport from the well-known Boston Fern; has a beautiful feathery appearance, and is one of the grandest of decorative house plants. Nice plants, $20 \mathrm{c}$ to $35 \mathrm{c}$ each; specimen plants, $\$ 2.50$ to $\$ 3.00$.

Boston Fern-One of the most beautiful and useful of house plants; is of easy culture.

Nice plants, each 20c; large plants,
Birds Nest (Asplenium Nidus Avis) - A rare and beautiful fern with broad outer leaves; centre curiously formed like a nest; color is deep green; an attractive pot plant for exhibition. Well-grown Specimens from 4-inch pots, $\$ 1.50$ postpaid.

Asparagus Plumosus (Climbing Lace Fern)-A finer and more delicate plant than the Sprengerii, but hardy and easily grown; very satisfactory for window and house culture; the fronds retain their freshness for weeks when cut; fine for floral decorations.

Nice plants, each $20 \mathrm{c}$; large plants, $25 \mathrm{c}$ to $40 \mathrm{c}$

FOR FERN DISHES-Attractive assortments, sufficient for 5 to 6 inch pans. From $75 \mathrm{c}$ to $\$ 1.00$, postpaid.

\section{Japanese Fern Balls}

Directions for Starting-Place ball in water for 15 minutes, and then suspend in any desired position, or place in a shallow dish; repeat every two days until growth is started, after which sprinkle occasionally as required. They need very little sun.

Price of Balls in dormant state, each $75 \mathrm{c}$.

We can supply any of above in all sizes from $2 \frac{1}{2}$-inch pots up to large specimen plants.

Prices, from 35c to $\$ 3.00$ each.

\section{DIAMOND PLANT FOOD}

For Ferns, Palms and House Plants. Clean, Odorless, Highly Concentrated

Produces Luxuriant Foliage --- Brilliant and Lasting Flowers. A 25-cent package will feed a dozen large house plants a whole year.

Price: 1/2-lb Pkg. 15 cts. Postpaid 25 cts. 1-lb Pkg. 25 cts. Postpaid 40 cts. 


\section{Palms and Ornamental Plants}

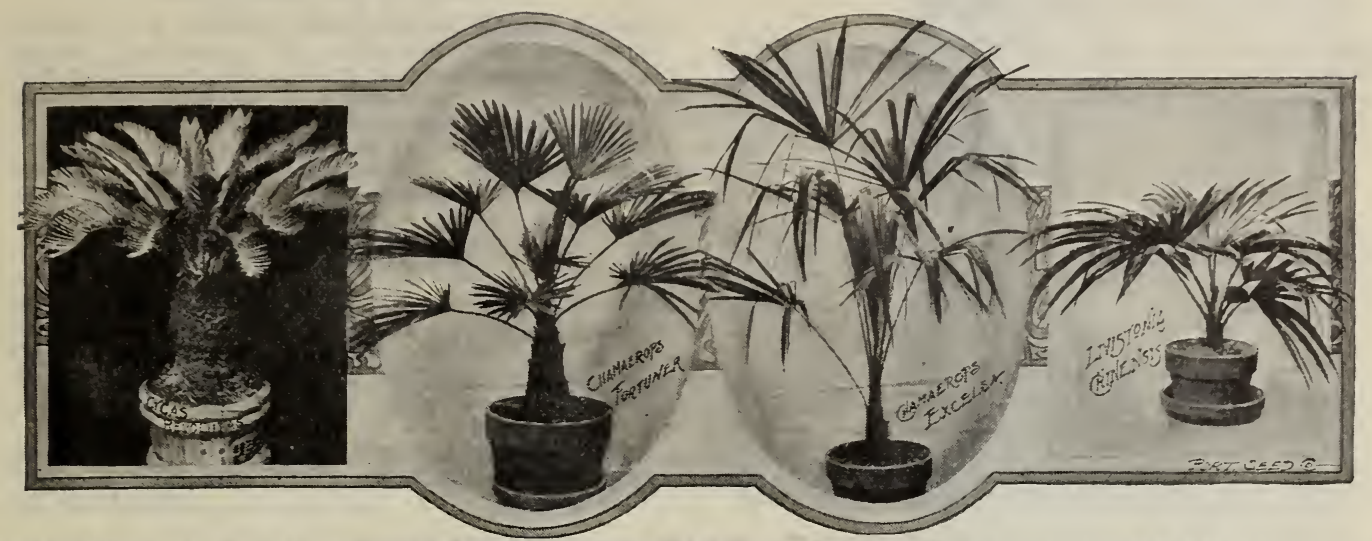

P AIMS lend to their surroundings an atmosphere of elegance and completeness, and with plants.

proper care will thrive in any home, making the most magnificent and useful decorative

CARE OF PAIMS.-Good garden loam, with a little sharp sand, is the best soil for palms, and good drainsge is of first importance-do not keep a palm too wet. If you set the pot in a jardiniere put omothing under the pot to let the water drain through. Never let water stand around the bottom of the pot. Water thoroughly but let it drain off, then when the soll begins to look dry give another good wetting. It is important to keep the soil of anj pot plant moist-clear through-but not vet like mud. One other important point: Soil must have light; palms and some plants would do well without strong light, but the soil would soon sour and fall to nourish them, therefore, when not actually in use keep them as near the windows as possible, bat not in the hot sun.

Bone meal is the best fertilizer; a tablespoonful to a 7-inch pot is a good proportion. Dig well into the soll. Apply when new growth shows. Do not repot as long as they are doing nicely. And when Jou do, transfer gently to the larger pot and fill the soil around the roots, disturbing them as little as possible. Palms do best in comparatively small pots. Shower them with water twice a week and should they show signs of scale, wash with strong soap and water or kerosene emulsion (a pound of soap melted with a half pint of kerosene thoroughly stirred into it). Dilute this with ten parts of water and apply with a cloth or brash.

\section{Palms}

Phoenix Roobeleni-A new and graceful min iature "Phoenix" fully equalling in beauty the Cocos Weddeliana, and having the advantage of being as hardy as the Kentia. Of vigorous bushy growth, with dark green recurving foliage. An admirable house plant. Price, choice plants from 4-inch pots, $60 \mathrm{c}$ to $\$ 1.00$.

Cocos Weddeliana-The most graceful of all Palms; finely cut foliage of rich deep green; we have fine plants of this most desirable Palm, well established in 4-inch pots, 5 to 7 leaves. Fach, $\$ 1.00$. Nice specimen plants, \$2.50 up.
Kentia Belmoreana-A beautiful, handsome looking, strong growing Palm with deep green, crisp foliage; inclined to dwarf and spreading habit; one of the most popular for house culture, as they are very hardy. Small plants $50 \mathrm{c}$ to $75 \mathrm{c}$. Iarge plants, 18 inches up, $\$ 1.50$ to $\$ 5.00$ and up.

Iivistona Rotundifolia-A miniature fanleaved Palm, having almost a globular form in well grown specimens. Beautiful for table; thrive well in the house. Price, from 4-inch pots, $75 \mathrm{c}$.

Thrinax Radiata-An attractive graceful species with palmate leaves narrowly divided. Price, from 4-inch pots, $75 \mathrm{c}$.

\section{Japanese Palms}

Livistonia Chinensis (See cut No. 4)-The most popular Palm for decorative work, for apartments, or conservatories; leaves large, fan shaped, of a rich dark green color; handsome, graceful and quick growers, 12 to 18 inches. Each, $75 \mathrm{c}$ to $\$ 1.00$.

Cycas Revoluta, Sago Palm (See cut No. 1)-These are magnificent plants, of noble and majestic habit, and most impressive; very valuable for both lawn and house decorations; they have a thick trunk, and their heary, glossy, deep green pinnate leaves resist alike the gas, dust and cold to which decorative plants are frequently exposed; fine plants, large trunks, with well branched leaves at the top, 18 inches and up.

Each, $\$ 3.00$ to $\$ 5.00$ and up.
Chamaerops Excelsa (See cut No. 3)-Leares fan shaped, deeply cut; one of the hardiest Palms we have and worthy of extensive culture; very ornamental, a symmetrical grower and has very handsome palmate leares.

Choice plants, 18 inches and up, eacil $\$ 1.50$ to $\$ 3.00$. Chamaerops Fortunel (See cut No. 2)-A handsome Palm, similar to the above, more dwarf in growth and with smaller leaves; we import the Ohamaerops, Livistonia and Cycas Palms from Japan.

Choice plants, 18 inches up, each $\$ 1.50$ to $\$ 3.00$.

Rhapis Humilis-Rare ornamental Palm with slender, graceful leaves; very handsome and attractive; an excellent decorative variety, requiring very little sun. Each, $\$ 2.50$ to $\$ 5.00$.

\section{DRACANAS}

D. Godseffiana-Distinctly different from other Dracaenas. Has free branching, graceful, compact habit; foliage of strong leathery texture; color, fine dark green, mottled creamy white; a splendid plant for fern dishes. From 3-inch pots, 50c.
D. Indivisa-This is the popular hardy Dracaena that is used so extensively for centers of vases, baskets, boxes, etc. Of graceful form, and stands full exposure to sun. Price, 35c to $\$ 1.50$.

D. Fragrans-Foliage broad, color, rich dark green; makes a splendid house plant; requires no special attention. $\mathbf{E a c h}, \mathbf{7 5 c}$. 


\section{ORNAMENTALS PLANTS - Continued}

\section{Umbrella Plant}

Cyperus, Umbrella Plant (Alternifolia)-A splendid house plant of easy culture; resembles a palm; requires little or no attention, and remains green throughout the year. Keep well watered.

Small plants, postpaid, each $15 \mathrm{c}$ to $25 \mathrm{c}$.

Large plants, by express, each $35 \mathrm{c}$ to $\$ 1.00$.

\section{REX BEGONIAS}

Rex Begonias-Truly the king of foliage plants; leaves large, variegated and margined with a peculiar silvery metallic gloss; fine for baskets, boxes or windows; we offer 20 of the finests sorts.

Choice plants, mailing size, each $25 \mathrm{c}$, postpaid.

\section{CYCLAMEN}

Cyclamen-Fine healthy specimens; red, white, pink, rose, salmon and variegated; ready to bloom; nothing is more beautiful or acceptable as a holiday gift. 4 to 6 -inch pots, each $75 \mathrm{c}$ to $\$ 1.50$. Must go by express, purchasers' expense.

\section{Araucaria Excelsa}

(Norfolk Island Pine)-This beautiful plant resem. bles the pine somewhat in appearance, though much finer in texture; it is particularly adapted to parlor table decoration; it is most unique in appearance, the branches being arranged in neat, symmetrical whorls; they do not require much sun and are hardy and easily cared for. Choice plants, 14 to 20 inches high, each $\$ 2.00$ to $\$ 4.00$.

\section{Rubber Plant}

Ficus Elastica-This is certainly one of the best plants grown for decorative purposes; it succeeds well with ordinary treatment; its glossy, thick dark green leaves are not affected by dust or gas; the large dark green foliage and erect form are much admired.

Large plants, each $75 \mathrm{c}$ to $\$ 1.50$ and up
Variegated-Beautifully marked with creamy white. nice plants.

Each $\$ 1.50$ up

\section{JAPANESE ORNAMENTALS}

W

E import annually large assortments of Japanese Plants, Palms, Shrubs, etc., and would call attention to the splendid values offer ed in these interesting specimens.
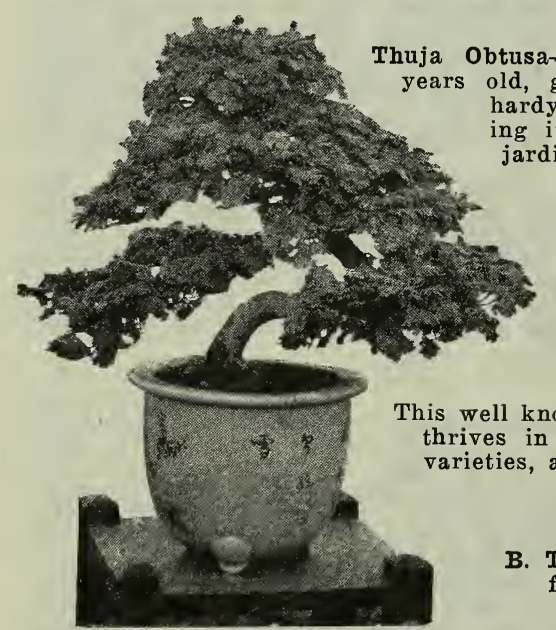

Aspidistra

Oramental foliage, plant throwing up shoots which unfold, developing into long, graceful leaves; color a beautiful dark glossy green; give same treatment as hardy palm.

Specimen plants, $\$ 2.00$ to $\$ 3.00$ each. Variegated-Rich creamy markings. Specimen plants, $\$ 3.00$ each.

\section{Camellia}

Japonica-Very beautiful, winter flowering evergreen; the handsomest, shining, dark green foliage and magnificent, wax like flowers of various colors, render them indispensable for the conservatory, and well adapted for parlor or window culture; perfectly hardy in this climate in the open ground, but should be planted in a shady place and protected the first year. We have these in three colors. Double White, Pink and Red. $1 \frac{1}{2}$ to 2 feet, each, $\$ 1.00$ to $\$ 1.50$

\section{Daphne}

Odora-A very pretty early flowering shrub, producing pink flowers in March. 2 feet, each, $\$ 1.00$ Alba-Pure white. 2 feet, each, $\$ 1.00$

\section{Sciadopitys Verticillata}

"Umbrella Pine"-The leaves are narrow, round and arranged in whorls of umbrella like tufts; is especially adapted for porch or lawn decoration. (See cut below).

\section{Thuja Obtusa}

ucuba Japonica-Japan evergreen, with shining evergreen folEach, $75 \mathrm{c}$ to $\$ 1.00$ ucuba J. Variegata-Green and yellow foliage; very showy; fine for specimen plants on lawn. Large plants for immediate ef.

Each, $\$ 2.00$ to $\$ 2.50$

\section{Bamboo}

nt, with graceful and almost evergreen foliage, S, making fine lawn clumps. We have four
Strong clumps, 3 to 6 feet, each, $75 \mathrm{c}$ to $\$ 1.50$

\section{Berberry-Japanese \\ autumn; good hedge plant.}

2 to 3 feet, each, $60 \mathrm{c}$ to $75 \mathrm{c}$

\section{Cryptomeria}

One of the finest evergreens of Japan; of both up. right and drooping habit. We import a number of different varieties all of which are suitable for lawn planting. Folliage mostly needle like; end of branches soft and flexible.

1 to 2 feet, each, $\$ 1.00$ to $\$ 2.50$

\section{Lilac-Tree}

Syringa Japonica-Japan tree lilac, growing to a height of 30 feet; blooms late in June, bearing large pannicles of showy white flowers carried well above the foliage; leaves large and leathery, rich dark color.

Each 75c

\section{Quince (Japan Flowering)}

Japonica-Remarkable for the brilliancy of its blossoms, which vary from the richest scarlet to the most delicate blush color; the fruit is deliciously fragrant, but is not edible.

2 to 3 feet, each, $60 \mathrm{c}$ to $75 \mathrm{c}$

Alba-A very beautiful variety, with delicate, white and blush flowers. $\quad 3$ to 4 feet, $75 \mathrm{c}$ to $\$ 1.00$

\section{Persimmon}

Japanese-Highly prized for its delicious fruit. We import the Japanese variety valled Hyakume. Fruit large and oblong; color bright red; ripens early in the fall. 4 feet, each, $60 \mathrm{c}$ to $75 \mathrm{c}$ 


\section{Japanese Ornamentals-Continued}

\section{Maple (Japanese)}

Japanese Maples are becoming more popular as they become better known. They are all of dwarf habit and are varied in their foliage and are all so shrub-like in growth and many of them of such rich, bright hues and deep-cut leaves that we class them by themselves. On account of these characterictics they are much used for forming permanent beds, but are very ef fective wherner planted singly or in groups. We include only those we can especially recommend. Well branched, chorce trees, 2 to 3 feet. $\quad$ kach, $\$ 1.00$ to $\$ 1.50$

Atropurpureum-Large palmate leaves; deep maroon; very showy.

Atropurpureum Dissectum (Cut-Leaved Purple)-Dwarf weeping. graceful form, branches crimson; leaves deeply and finely cut into shred like dirisions; of a beautiful rose color when young, changing to a deep, dark purple. A choice and ornamental variety.

Atropurpureum Dissectum Variegatum-Like the above, except that the leaves have a white edge, making them very showy and attractive; very popular sort.

Atropurpureum Variegatum-Leaves large and scalloped; color bright crimson, with deep maroon variegation.

Sanguineum Seigen-Regular palmate leaves, coloring in the middle spring to a blood red; very handsome.

Scolopendifolium Rubrum-Dark red; finely cut; narrow ribbon leaves.

\section{Magnolia}

Magnolia Salicifolia-New species called fragrant Magnolia; pure white flowers. It emits a sweet aromatic scent, not only from the flowers, but stem and leaves; very hardy; should be in every collection.

Each $\$ 1.50$ to $\$ 2.00$

Conspicua-A Chinese species of great beauty. The tree is of medium size, shrub like in growth while young, but attains the size of a tree in time. The flowers are large, pure white, very numerous and appear before the leaves.

2 feet, each, $\$ 1.00 ; 3$ feet, each, $\$ 1.50$ to $\$ 2.00$

Soulangeana-In habit it closely resembles M. Conspicua; flowers white and purple, cup-shaped and three to five inches in diameter; foliage large, glossy and massive; it forms a handsome tree; blooms later than Conspicua.

2 feet, each $\$ 1.00 ; 3$ to 4 feet, each $\$ 1.50$ to $\$ 2.00$.

Magnolia Obovata-Exterior petals purple, veined with deeper color, white center.

Grandiflora. See page -

Each, $\$ 1.00$ to $\$ 1.50$.

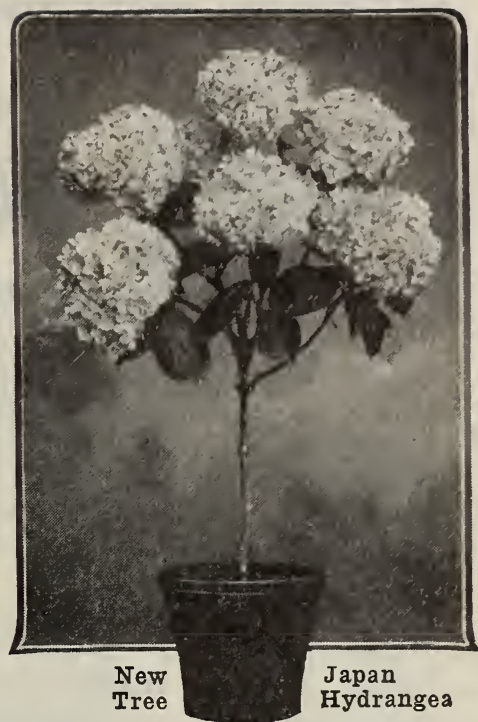

Hydrangea

New-Tree Hydrangea

We offer this new tree form for the first time; our direct importation. A most interesting and valuable novelty. strong plants. Each $\$ 1.00$

Hortensis Blue-Very fine Japanese variety for potting and porch decoration; large flowers, rosy blue to light blue, according to the soil. Strong clumps, each $75 \mathrm{c}$ H. Hortensis, pink, fine truss, pure pink, each $75 \mathrm{c}$ Prunus

We import these direct from Japan. They are hardy, rapid growers, and produce early in the spring a profusion of handsrme flowers of great beauty and fragrance.

Prunus Mume-The Flowering Plum. Double White or Double Red, 3 feet up, each, $75 \mathrm{c}$ to $\$ 1$

Prunus Cerasus-Handsome Flowering Japanese Cherry.

White, pink or red, 3 feet up, each $75 \mathrm{c}$ to $\$ 1.00$

Prunus Pissardi-Flowering Plum. Wood and leaves dark purple. 3 feet up, each, $75 \mathrm{c}$ to $\$ 1.00$

\section{Japanese Tubs-Porch Boxes-Hanging Baskets}

Made up to order in any color scheme or special design

\section{Pruning Tools, Labels, Stakes, Etc.}

\section{PRUNING SHEARS}

We have a fine assortment, ranging in prices from $50 \mathrm{c}$ to $\$ 1.25$ each, postpaid.

\section{LONG-HANDLE TREE PRUNERS}

Six feet, $75 \mathrm{c} ; 8$ feet, $\$ 1.00 ; 10$ feet, $\$ 1.10 ; 12$ feet, $\$ 1.25$. Cannot go by mail. Purchaser will have to pay freight or express charges.

\section{BRANCH SHEARS}

Twenty-six-inch handle, $\$ 1 ; 41$-inch handle, $\$ 1.25$. PRUNING SAWS

Crescent-12-inch blade, $65 \mathrm{c} ; 14$-inch, $75 \mathrm{c}$.

Straight Blades-16-inch, 60c; 18 -inch, $65 \mathrm{c} ; 20$ inch, $70 \mathrm{c}$.

Price, $1 / 4$ lb., 10c; $1 / 2$ lb., 20c; $1 \mathrm{lb} ., 35 \mathrm{c}$; postage, 20 c per lb. extra.

\section{RAFFIA}

For tying plants and buds. Pound, 25c; by mail, $50 \mathrm{c}$

\section{FTORISTS' MOSS}

Clean and bright, in bales; $\$ 3.00$ per 100 .

\section{BUDDING KNIVES}

Best grade, from $25 \mathrm{c}$ to $\$ 1.00$ each, postpaid.

GRAFTING KNIVES

Wood handle, stationary blade, $25 \mathrm{c}$ to $35 \mathrm{c}$ each.

\section{PRUNING KNIVES}

Best grade, from $50 \mathrm{c}$ to $\$ 1.50$ each, postpaid.

\section{WOODEN LABELS}

Tree Labels-Painted, wired, per $100,15 \mathrm{c}$; per M, $\$ 1.00$; unpainted, per M, $85 \mathrm{c}$; painted, copper wired, per 100, 20c; per $M, \$ 1.10$.

Pot Labels-4-inch, painted, per $100,15 \mathrm{c}$; per $\mathrm{M}$, $80 \mathrm{c} ; 5$-inch, per $100,20 \mathrm{c}$; per $\mathrm{M}, \$ 1.05$; 6-inch, per $100,25 \mathrm{c}$; per $\mathrm{M}, \$ 1.40 ; 8$-inch, per $100,30 \mathrm{c}$; per $\mathrm{M}, \$ 1.75$.

\section{PLANT STAKES}

Round Cedar-Painted green, white tops, 3-foot, $85 \mathrm{c}$ dozen; $3 \frac{1 / 2}{2}$-foot, $90 \mathrm{c} ; 4$-foot, $\$ 1.00 ; 5$-foot, $\$ 1.50 ; 6$-foot, $\$ 2.25$.

Bamboo-4-foot, doz., 25c; 5-foot, 35c; 6-ft., $40 \mathrm{c}$.

FLORISTS AND COMMERCIAL GROWERS: We carry the largest line of Florists' Supplies in the Northwest. Prompt deliveries at right prices. A trial order will convince. Send for trade list. 


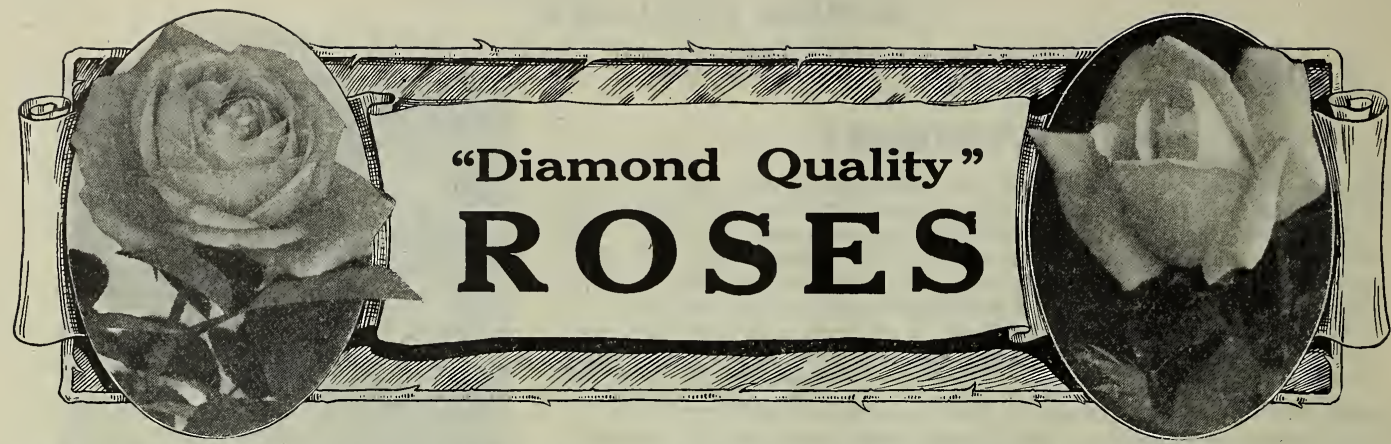

W $\mathrm{E}$ offer only the best of the standard varieties and the newer sorts that have been tested in field trials. You will find them true to name and as represented. We number among our customers the most successful rosarians in the Northwest, and if you entrust your rose order to us you can feel assured that there will be careful selection and no substitution. If you do not find what you want in this catalog, write us. We can supply many varieties not listed.

\section{Shipping}

We always send all our two-year-old rose bushes charges collect by express or freight, packing them so they will ship safely, even though they should be on the road for two weeks or more.

If necessary, we can send small two-year-old bushes by mail at an additional cost of $7 \mathrm{c}$ each to cover postage, but in such cases we always prune the tops and roots ready for planting.

\section{PLANTING AND CARE}

In our favored section Roses attain a perfection seldom equalled, but you cannot expect them to thrive and bloom unless you care for them. We offer the following simple suggestions.

Soil-Any good, well-drained garden soil enriched with fertilizer will give excellent results. If heavy clay soil mulch well with burnt earth and manure, rotted sod or leaf mold.

Watering-When setting out, water regularly until roots are well set; then about once a week unless the ground is very dry; in such cases more often. Do not get the foliage wet after a hot day. This causes mildew.

\section{Beautiful Roses of Recent Introduction}

Twelve magnificent new roses imported direct from famous Irish and Continental growers. SPECIAI-One each of these 12 grand new roses, $\$ 10.00$ prepaid.

\section{RAYON D'OR}

The finest, deepest colored, and only pure yellow, everblooming Rose.

RAYON D'OR-Pern. Flowers are large, full, open freely, keep. well and are borne in greatest profusion. Buds long pointed of deep orange cadmium smeared claret, opening to a rich sunflower yellow which does not fade. Foliage is deep glossy green, strong growing, free branching and absolutely free from the attack of mildew. This splendid new Rose, a cross between Melanie Soupert and Soliel D'Or is producing a greater sensation than was caused by Lyon, both these wonderful varieties originating from the same source. Stock of Rayon D'Or will be scarce for some time to come and we urge that you place your orders at once. Price, each, \$2.00

IADY AIICE STANIFY-This grand new gold medal rose is large, very full and of splendid substance; petals shell shaped, pointed, giving perfect form to the flowers, which are a lovely deep coral, inside pale flesh, deliciously fragrant and are very lasting. A free grower and a profuse and constant bloomer.

MRS. HAROID BROCKIFBANK - H. T. Creamy white, center buff, base of petals yellow, outer petals tinted salmon rose; large, full, free and perpetual $\mathbf{F a c h}, 75 \mathrm{c}$
When planting cut back freely, and the bush will recover quickly.

Fertilizer-Our odorless commercial fertilizer Bone Meal, Tankage or Blood will give excellent results, and should always be applied after the plant starts its growth.

Finally-Keep the surface well worked around the roots. This is as necessary as water or fertilizer.

Womplete practical information on Rose IADY HIIIINGDON-T. Deep apricot yellow, long and pointed bud, a fine forcing or garden. Rose, excellent for cutting. Flowers are of good substance, very lasting and foliage handsome and luxuriant. Lady Hillingdon is considered the best decorative rose in its class. This aristocratic beauty is a seedling from Papa Gontier and $\mathrm{Ma}$ dame Hoste. Price, $\$ 1.25$

JONKIER J. I. MOCK-A magnificent and unique Rose. Inside of petals red, outside silvery blush white. Of fine form, good substance and largest size. A strong, rapid grower. This rose has been awarded eight prizes at the recent European shows. Price, 81.00

AIBATross-H. T. Ivory white, faintly tinted blush, large, full and free, vigorous and erect. One of the best white roses ever offered. Splendid for garden or exhibition. $\quad$ Price, $\mathbf{7 5 c}$

COMMANDER JUIES GRAVERAUX-H. T Fiery crimson, lightly shaded velvety maroon, purple in the center, a seedling of "Druschki," which it is said to greatly resemble in habit, growth and foliage. Buds are long and spiral. Come singly, and upright on the stems; vigorous, erect and free blooming.

MRs. IONGWORTस-H. T. A very prettily striped sport from "Caroline Testout" with very narrow stripes and splashes of pale flesh.

Fach, 75c

Roses." Sent free to those interested. 


\section{TWELVE NEW ROSES - Continued}

MRS. E. G. FIII-H. T. Outside of petals coral red, inside alabaster white. Very large, full and opening freely; bud long and rose.

Each, 75c

IFNA-T. Rich apricot, edges of petals turning deep primrose as ...e flower ages a very beautiful and free garden rose commanding attention wherever shown

Each, 750 pointed. A grand decorative and exhibition

Ur PROGRבSS-H. T. Nankeen vellow, open ing to saffron vellow; large, full and cupped. opening freely: a grand rose always in flower.

rach, $75 c$

EIS MAJESTY-Dark crimson shaded deep vermilion crimson towards the edges. Large, full and very free; deep broad petals, with high pointed center: one of the sweetest perfumed roses. A vigorous grower carry-
ing its flowers upright.

\section{New Single Irish Roses}

CVRryoNE should have these finest new single roses, which cannot be excelled for garden decoration or cutting. They are now in great demand and the varieties offered are the best.

SPECIAI-One each of three varieties, $\$ 1.50$

IRISH SIMPICITY-Almost single, pure white and of immense size. The great size and substance of the petals which are slightly cupped and the golden yellow anthers may readily bring to mind the comparison to a huge water lily. Vigorous gromer with handsome deep green foliage.

Price, $75 c$

IRISH ELEGANCE - Large single golden bronze flowers of great beauty, free and constant bloomer, with deep bronze foliage, making a most handsome and unique combination that for garden decoration cannot be excelled. Awarded gold medal N. R. S.

Each, 50c

IRISH HARMONY-Single, saffron yellow, hearily crayoned claret in bud, when expanded changes to creamy white; large, lasting, floriferous; a vig orous grower, and gocd companion for Irish Elegance.

Each, 50c

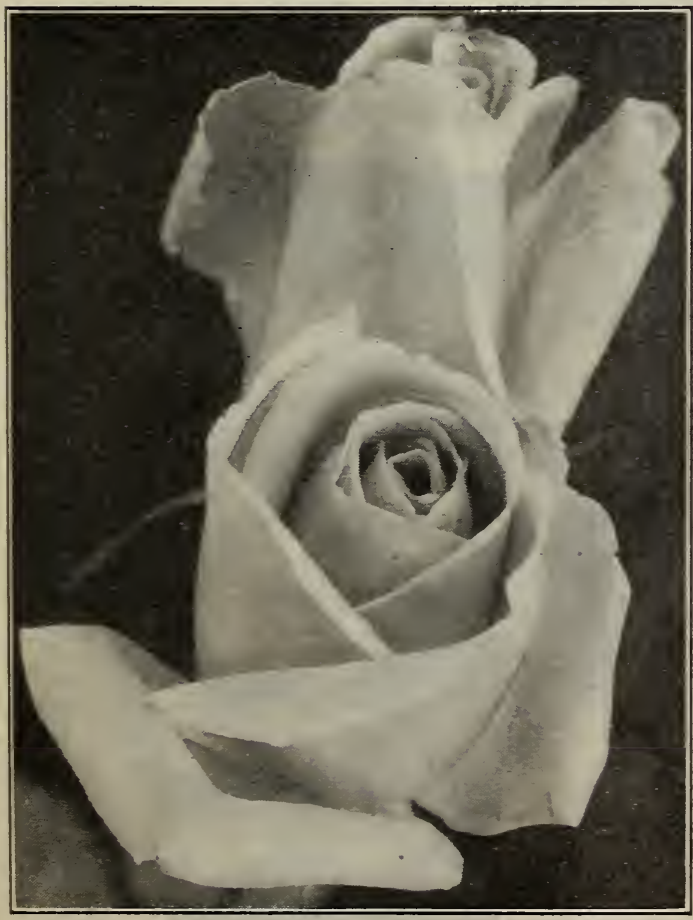

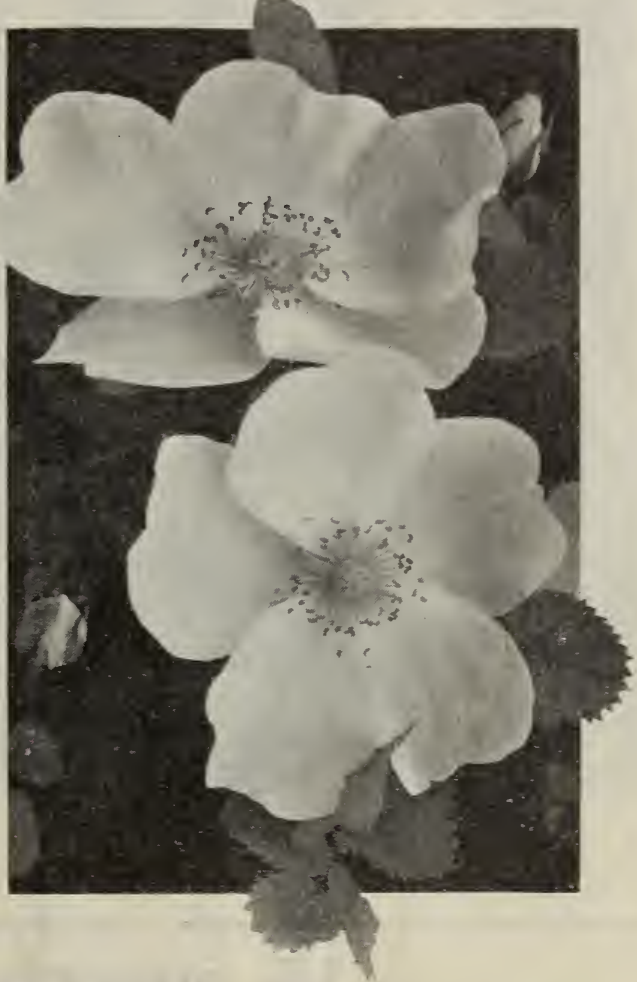

\section{Rare and Beautiful Roses}

Price, except where noted: Iarge, 2-year-olo plants, 60c each. The entire collection, 14 distinct vàrieties, only $\$ 8.00$.

WHITE KIIIARNIY-The finest ever-blooming white Rose for cut flowers. The long pointed buds are of ideal form, petals purest white and heary $\pi$ axlike texture, remaining a long time in bud. Flowers are full and beautiful when open and are very lasting. White Killarney is the freest blooming of the white Roses and is a thrifty, vigorous grower, not subject to disease or mildew. Choice two-year-old plants, Each, 75c DOROTHY PAGE ROBERTS-H. T. Coppery pink, suffused with apricot yellow, very free and perpetual, a delightful garden Rose.

EIIZABETE BARNIS-H. T. Satiny salmon Rose with famn center, suffused yellow; outside of petals rosy red, tinted copper and yellow; flowers large, full and freely produced.

HARRY KIRK-H. T. Deep sulphur yellow paler towards edges of petals, long pointed bud, moderately full; a fine garden Rose.

MAD. SEGOND WIBBER-H. T. Pure, rosy salmon, vivid center, large, full and perfectly formed flower, flowering freely and continuously on stiff erect stems.

MRS. DAVID JARDINE-H. T. Delightful shade of bright rosy pink, shading in outel petals to salmon pink, large, perfect form, very highly perfumed; a grand Rose. 


\section{RARE AND BEAUTIFUL ROSES - Continued}

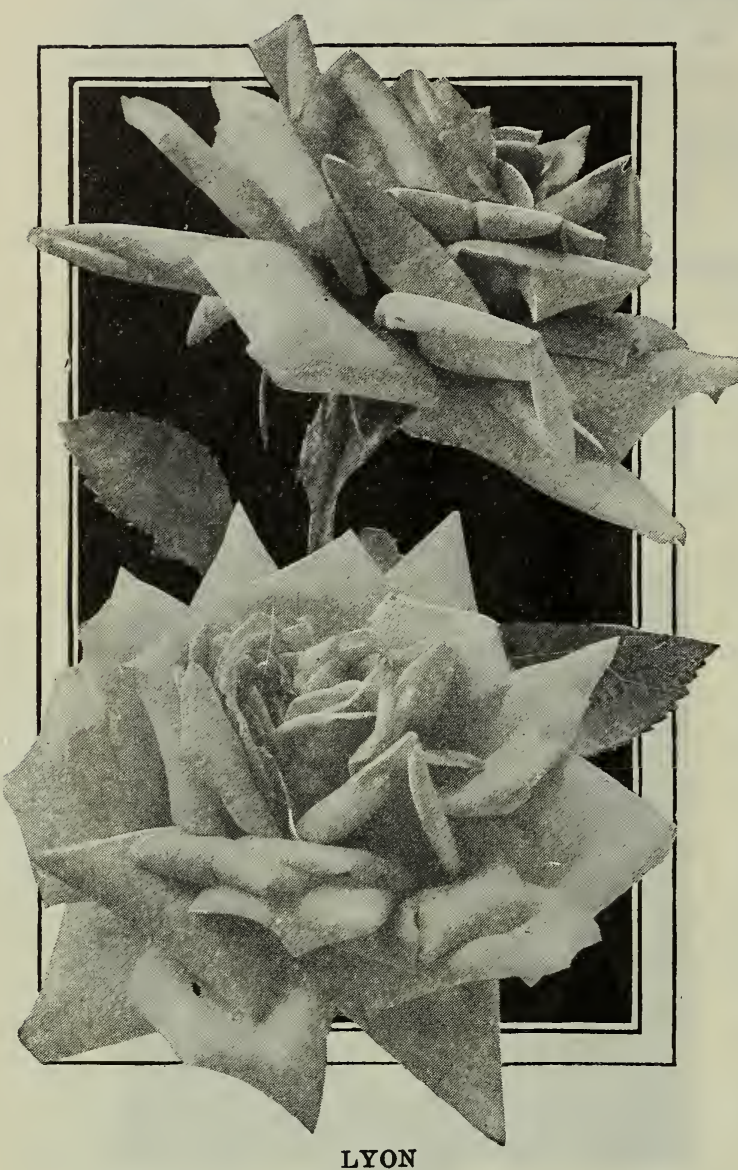

MOIIY SHARMAN CRAWFORD-T. Delicate eau-de-nil white, opening to dazzling white; large, full, free and constant.

Price each, 75c

DUCHESS OF PORTLAND (H. T.) -One of the best Dickson introductions; a lovely pale yellow with thick leathery petals, full and perfect form; hardy, robust rose blooming earlier and more freely than "Kaiserin"; long stems; lovely in bud or flower, and a good keeper. Gold medal N. R. $\mathbf{S}$.

Price, 60c

MRS. AARON - WARD (H. T.)-Color a shade of Indian yellow washed with salmon rose; large size cup-shaped, very full and very floriferous. Long beautiful buds, petals reflexed. Fine bronze foliage, very hardy and vigorous.

MRS. ARTHUR ROERRT WADDEII-Fine, robust growing variety of great merit. Buds rosy scarlet, opening into large, reddish, salmon-colored flower. Very rich and striking color.

MARQUISE DE SINETY ( $H$. T.)-Golden orange shading to fiery red, large double flowers, of good form, very beautiful and attractive. A splendid garden rose for summer blooming; vigorous and hardy. One of the grandest of the new roses.

RHEA REID (H. P.)-A new American rose which can best be described as being as red as a "Richmond," as large as an "American Beauty," with the fragrance of "La France," and blooms con. tinuously, flowers being borne on long stems; very hardy and vigorous. Gold medal Paris, 1908.

CHATEAU DE CLOS VOUGEOT (H. T.)-Deep velvety scarlet, shaded fiery red; darkens as it fully expands; vigorous, handsome foliage; a splendid rose, one of the best colored of the darker reds.

LYON (Pernetiana) - The Lyon is a beautiful shrimp pink with salmon and chrome yellow shadings. Large coral red buds beautifully formed; full globular flowers of rare beauty; a continuous and free bloomer. Lyon is the "perfect rose," only one scoring 100 points. Gold medal and special certificate awards.

Price, 75c

\section{Superb Garden Roses}

An incomparable collection suitable for garden or exhibition.

NOTF.-Special reduced price-Iarge field grown, two-year-old plants, each, 50c; dozen, \$5.00. An extraordinary value.

DEAN HOLE-Beautiful silvery carmine, shaded bright golden pink; grand flowers of great sub, stance, perfect in form; vigorous, free branching habit; continuous bloomer; one of the best exhibition roses. Gold medal N. R. S.

FLORENCE PEMBERTON (H. T.)-Creamy white, suffused pink. Flowers very large and full of perfect form and wonderful substance. Without doubt one of the finest roses it has yet been our pleasure to offer. GENERAI MCARTHUR (H. T.)-Dazzling crimsop scarlet, a grand American rose of ideal form, delicious perfume and magnificent foliage. Blooms continuously in great profusion, the grandest red rose for garden or cutting. HUGH DICKSON (H. T.)-Glowing crimson, shaded scarlet: large, full, perfectly formed, delightful perfume, strong grower, perpetual bloomer (should be cut back freely.) After careful comparative tests, we believe Hugh Dickson is the best hardy red garden rose to date. See cut on cover.

HON. INA BINGHAM (H. T.)-Beautiful shade of bright pink, distinct in form and color, of good substance, highly perfumed; a hardy robust garden rose.

FREIHERR VON MARSCHALI-From what we have observed of this variety during the past two years we have had it on trial, it will fill a long felt want. Color dark carmine with long pointed buds, the open bloom of large globular form and great substance.

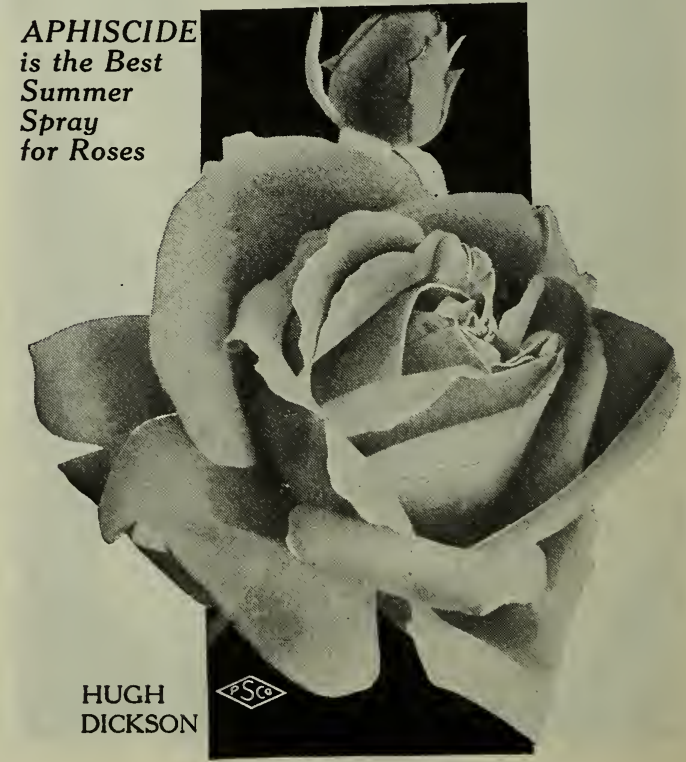




\section{SUPERB GARDEN ROSES-Continued}

FRIEDRICHSRUH (T.)-Blood-red, large, full, of perfect form, and flowers continuously; excellent habit of growth. Awarded gold medal at Dus. seldorf. A valuable addition to the tea section.

JOSEPE HILI-H. T. A rare combination of clear salmon, bright pink and pure gold, large beautifully formed, a distinct rose. Growth very vigorous, flowers borne erect on heavy stiff canes; foliage dark and lustrous.

MY MARYLAND (H. T.)-Beautiful bright pink, with paler edges; delightfully fragrant; robust grower and very free flowering; flowers full and good keeper. This is the most popular rose novelty of the duy, and best pink of its color; specially fine for florists, as well as being one of the grandest garden roses.

WM. SHEAN (H. T.)-Pure bright pink, reined with ochre, large perfect form, pointed bud, of fine substance and a grand exhibition rose. Gold medal N. R. S.

MADAME LEON PAIN-Robust growth; handsome plum-colored foliage; flowers large, full and free in opening; silvery-salmon, center orange-yellow, reverse bright red and sellow.

MADAME MELAINE SOUPERT (H. T.)-Splendid new orange yellow/shaded pink; beautiful longpointed buds, large size, free blooming; s strong. upright grower; best of its color.

LADY ASHTOWN (H. T.)-One of the finest pinks, of a rich, deep, silvery tone; flowers large, perfect form; free blooming; vigorous; Lady Ashtown is one of the finest roses grown.

IADY ROBERTS (T.)-Rich apricot, base of petals coppery red, edges of petals shaded orange, bud long and pointed very beautiful. Gold medal N. R. S. Be sure to order Lady Roberts.

PRESIDENT W. R. SMTTH (Maidensblush)-a superb new rose of American origin, producing elegantly shaped buds and open flowers of much beauty. Of an exquisite silvery pink color and sweetly perfumed.

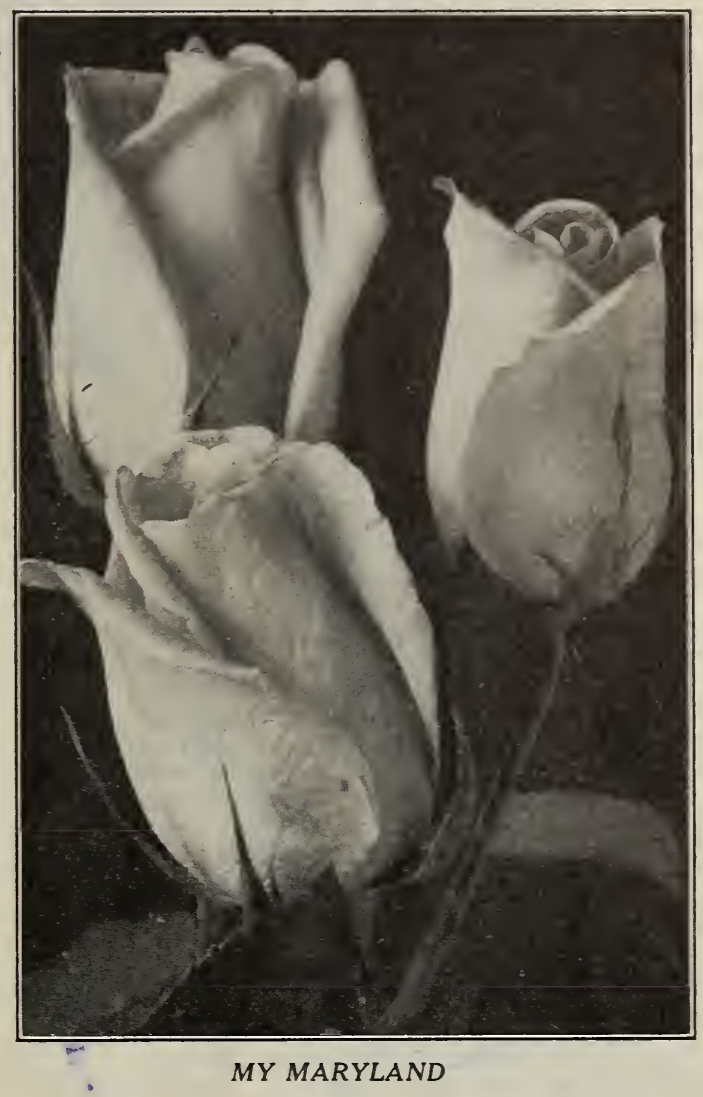

\section{Grand Garden Roses}

Iarge two-jear-old field grown plants,each, 40c; dozen, $\$ 4.00$.

These splendid free blooming Roses are newer varieties that are becoming more plentiful and can be offered at a very low price. In this list you will find many famous prize.winners and some of the most beautiful and popular roses.

BETTY-A very popular new rose of rare new shades of ruddy gold, suffused with golden yellow; blooms of enormous size; delicious perfume; large petals of good substance; foliage massive and beautiful; a true everblooming hardy rose.

COUNTESS OF GOSFORD (H. T.)-Clear salmon pink, base of petals shading to saffron yellow, very vigorous; perpetusl bloomer; a grand bed. ding variety.

FRANZ DEEGAN (H. T.) -A splendid garden rose of unusual beauty and form; strong, healthy grower. The buds are long and pointed. The open flower is broad and full, rarely showing the center. Color, yellow; bright and pleasing.

J. B. CLARK (H. T.)-One of the finest of the new roses. Its glorious flowers sre intense scarlet, shaded blackish crimson, of giant size, finely formed and fragrant; growth vigorous and upright.

EILIARNEY (H. T.)-Color, an exquisite shade of deep shell-pink lightened with silvery-pink. Buds are exceptionally long and beautifully formed; delicate tea-rose fragrance.

MRS. EDWARD MAWLEY (T.)-Beautiful silvery pink, with creamy yellow suffusion at base of petals; a magnificent rose of finest form, extrs long pointed buds; petsls of grest substance, beautifully reflexed; buds solid, flowers full; freeblooming, vigorous grower, and good keeper; a gold medal rose of distinctive form and great value. (See cut.)
IA DETROIFe- besutiful shell-pink shading in - the center to \&. 5 ft rose-pink. Reverse of outer petals creamy-flesh tint, strong, healthy grower; prolific bloomer; delightful tea fragrance.

SOUV. DE CATHERINE GUIIIOT (T.)-Orange ret, tinted coppery carmine on deep gold; a rare color; buds of perfect form, large, full, fragrant; a vigorous, free bloomer; fine exhibition sort.

MADAMP PHIIIIPPE RIVOIRE-H. T. Beautiful apricot yellow and Nankeen yellow center, reverse of petals carmine; large, full and globular, a splendid free blooming Rose.

SOLEIL D'OR (Pern.)-(Golden Sun)-The first of a new type and from which the wonderful Lyon Rose wss developed. A perpetusl bloomer, robust grower, brownish wood, foliage beautiful, bright green snd scented. Flowers very double, most beautiful when full blown, \& superb color, vary. ing from gold and orange yellow to reddish gold and shaded with nasturtium red. Delightfully fragrant.

PRINCE DE BULGARIE (H. T.)-A deep rosyflesh, salmon center; large, full, free-blooming, vigorous rose, easily maintains its great popularity, and is the best of its color.

RICHMOND (H. T.)-The most vivid of everbloom ing red roses; buds and flowers of the most perfect and desirsble form. The best of its color. 


\section{Favorite Hardy Garden Roses}

\section{Two Year old Field Grown Plants}

Prices, each, 35c; $\$ 3.00$ per dozen, unless otherwise marked.

ANNA DE DIESBACH-Beautiful, clear, carmine pink; very large, full and delightfully fragrant.

ANNA OLIVIER (T.) -A splendid ever bloomer. Very beautiful in bud; flesh color shading to blush. Large and fragrant.

AMERICAN BEAUTY-One of the largest, sweetest and best. Color, rich, rosy crimson, shaded and and veined in the most charming manner.

BABY RAMBLER-A Dwarf Crimson Rambler not over 18 inches high, producing large trusses of light crimson flowers; clean dark green foliage; it will flower the year around.

BESSIE BROWN-Color, pure white, sometimes faintly flushed pink.

BELLE SIEBRECHT-A true, solid pink of the richest shade, a rare color. The flowers are sweetly perfumed and large, beautifully formed, of long, tapering shape, with high center.

BARONESS ROTHSCHILD (H. P.)-Flowers of immense size; color bright, rosy pink:

BRIDESMAID-A fine, clear, dark pink color.

CAPTAIN CHRISTY-Color is lovely pale peach, deepening at center to rosy crimson.

CONRAD F. MEYER (Rugosa)-Beautiful silvery pink, of grand form and delicious fragrance, hardy in any climate, and the great beauty of its handsome foliage makes it most valuable for a flowering hedge.

CECIIE BRUNNER-Bright rose, yellowish in center; very sweet; dwarf polyanthus.

DUCHESS DE BRABANT-Color, a soft, rosy flesh, changing to deep rose, shaded amber and salmon; delightful tea scent.

DUCHESS OF AIBANY:Similar to La France, but more vigorous in growth and much deeper in color. The color is a bright rosy pink, exquisitely shaded. One of the best woses for general planting.

ETOILE DE FRANCE-This new crimson rode is of vigorous, healthy growth; color rich, glowing crimson, shaded with vermillion.

ETOILLE DE LYON (T)-Blooms freely, and every flower is a gem, equaling the Marechal Neil in size. Very sweet scented; color, rich golden yellow.

FRAU KARI DRUSCHKI (H. T.)-The White Americaltmbeauty. Makes splendid buds and immense flowers; perfectry touble and delightfully fragrant; large, thick petals ; wright, shming green leaves, elegantly veined; a health vigorous growor; and a constant and abundant bloomer.

GENERAI JACQUEMINOT-Bright, shithing crimson; very rich and velvety.

GLOIRE IYONNAISE-Color, chamois yellow, deener est at the center. passing to creamy white.

VIRGINIA R. COXE or GRUS AN TEPIITZColor, fiery crimson, with a dark velvety sheen, very fragraut. The freest blooming rose in exist-

ence.

KAISERIN AUG. VICTORIA-A beautiful rose with elegant, large pointed buds; delicate creamy white; deliciously fragrant; constant bloomer.

LA FRANCE-Both flowers and buds are of grand size: color, \& silvery rose changing to pink.

LIBERTY (H. T.)-Color, rich, fiery ruby, shaded deep crimson; fragrance exquisite.

LADY BATTERSEA (H.T.) - This variety has long: oval buds, sharply pointed, very striking in form. The color is a bright, cherry crimson; an unusually showy variety.

Each, $40 c$

MABEL MORRISON (H. P.)-Of the purest white; velvety in its appearance; petals thick and shellshaped; very double and rounded.

MADAME CAROLINE TESTOUT-A grand rose of the La France type, but with flowers larger and finer. Color, bright satiny pink; very fragrant and free in bloom. The official Portland "Carnival Rose.'
MADAME ABEL CHATENAY-A free bloomer, beautiful rosy carmine, with darker shadings.

MADAME FRANCISCA KRUGER-Beautiful coppery yellow, deeply shaded.

MADAME JULES GROLEZ-A rampant grower, with very large full flowers of a magnificent satin rose color extra fine.

MAMAN COCHET-This is one of the most beautiful new Tea roses we list. The color is a deep rosy pink, inner side of petals silvery rose.

MARGARET DICKSON-Magnificent form; white, with pale flesh center; petals very large.

MRS. JOHN LAING-Very free flowering; color, a soft delicate pink, with satiny tinge.

MRS. R. G. SHARMAN CRAWFORD (H. P.)Lovely deep rose pink, outer petals shaded pale flesh, base white, a new and unique shade. Large perfect flowers, free blooming; a grand autumn rose.

MILDRED GRANT (H. P.)-Delicate pale pink, shading to silvery white in center; grand giant variety of rare beauty; perfectly formed, pointed buds; full flowers of fine substance; a hardy, strong grower.

MARIE VAN HOUTTE-Of .a fine. faultless strawyellow color; washed and outlined rosy carmine.

PERLE DES JARDINS-A clear golden yellow, an indescribably rich and beautiful shade.

PERIE D'OR (Poly.)-Nankeen yellow with orange center; a dainty and beautiful Rose of the Baby Rambler type.

PAPA GONTIER-Large and semi-double; a vivid cherry red color, shaded yellow, reverse of petals crimson.

PAUL NEYRON-Deep, shining rose, double and handsomely formed; blooms freely, the largest variety in existence.

PRINCE CAMILLE DE ROHAN-Very dark, rich velvety crimson, passing to intense maroon.

RAINBOW-Buds and flowers of large size, color a beautiful shade of deep pink, distinctly striped and mottled with brilliant crimson.

SAFRANO-Bright apricot yellow, tinged orange.

SOUV. DE PIFRIE NOTTING-The bloom is large, perfectly full, of elegant form; has a beautiful long bud; color, orange yellow, bordered in carmine-rose; vigorous, beautiful dark foliage.

SOUV. DE PRESIDENT CARNOT-This is a rose of extraordinary beauty, is elegantly formed, very large, full and deep and deliciously sweet. The color a lovely shell-pink, delicately tinted with golden fawn on rich creamy white.

THE BRIDE-One of the finest white roses. The buds are very large and of exquisite form.

ULRICH BRUNNER-Extra large, bold flowers, full and globular; color rich, glowing crimson.

VISCOUNTESS FOLKSTONE-Flowers borne on strong stems, with thick foliage; color, delicately tinted flesh, almost white.

WHITE IA FRANCE-A pure white La France, having just a breath of rose-tinted blush.

WHITE MAMAN COCHET-White, grand substance, immense size, exquisitely fragrant, and a free bloomer; buds long and pointed.

WINNIE DAVIS (H. T.)-One of the most beautiful of our light pink roses; lovely bright clear color; splendid form; a grand, hardy garden sort.

Oakville, Wash., March 22, 1911.

Gentlemen: My collection of bush roses I got from you two years ago are fine. Ny neighbors are talking of sending for a rose collection. They are certainly a fine lot of flowers. 


\section{ChiMBING}

Price, 1 year, $15 \mathrm{c} ; 4$ sorts $50 \mathrm{c} ; 2$ years, $35 \mathrm{c}$ each.

AAEDS PIIIAR (H. T.)-Rich velvety crimson; fine large full flower, cupped form; a hardy, free-blooming, freegrowing garden rose, of finest quality. CHROMATELLA (CLOTH OF GOLD) (O. T.)-A clear, golden zellow, large, very full and double.

CLIMBING BELLE SIEBRECHT (C. H. T.)-Flowers identical with bush type; vigorous climber; hardy.

Each, 50c

CLIMBING BRIDESMAID (T.)-Beautiful pink; profuse bloomer.

CLIMBING KAISERIN (MRS. ROBT. PEARY)-Flowers fine, ivory white, of heary texture, and large size.

CLIMBING IA FRANCE-Identicsl with the well-known La France; vigorous climber.

CLIMBING METEOR-Rapid grower; rich, dark, velvety crimson flowers.

CLIMBING MADAME CAROLINE TESTOUT-Covered during the whole season with immense globular flowers of the same beautiful shade of pink as seen in the bush sort.

CLIMBING PERLE DES JARDINS-Of vigorous climbing habit; flowers golden yellow, of immense size.

CLIMBING PAPA GONTIER (T.)-A "Native Sport" from the favorite bush Papa Gontier.

GLOIRE DE DIJON-Noted for the great size of its flowers, its delicate tea scent, and its shades of color, being a blending of amber, carmine and cream.

MARECHAL NEII-A magnificent deep golden jellow variety; so famous as to need no description; grown the world over for its immense yellow flowers; the finest rose of its color in existence.

\section{Favorite Collection-Climbihg Roses}

Price: Postpaid, $10 \mathrm{c}$ each; set of 6 sorts, $50 \mathrm{c}$. Two year-old plants, $35 \mathrm{c}$ each.

MADAME AIFRED CARRIERE-Extra large, full flowers, very double and sweet, and a most profuse and persistent bloomer; color, rich, creamy white, faintly tinged pale yellow and blush.

BEAUTY OF GLAZENWOOD-Bronzed jellow or copper and fawn color. One of our grandest climbing roses. Very hardy and a free bloomer. REINE MARIE HENRIETTE-A strong, vigorous grower; flowers large, full, and of fine form; color. glowing crimson, elegantly shsded.

CLIMBING FRAU KARI DRUSCEKI-Grand flower, pure white, identical with the bush type. Free blooming and extremely hardy; has vigorous climbing habit.

\section{Fine Climbers}

\section{Year Old Plants only}

ZEPHRINE DROUHWN (H. C.)-Flowers very largo and double, of a besutiful bright rose; hardy, rapid climber; foliage lururiant, without thorns; a free-blooming, desirable rose.
CAROIINE GOODRICH (CLIMBING JACQUEMINOT) (C. N.) - Free flowering crimson climber.

GLOIRE :DE DIJON AND REINE MARIE HENRIETTE GROWING TOGETHER

GAINSBOROUGH-Graceful flower of dainty shell pink color and satiny finish. Hardy, ever-blooming and a free climber.

WILLIAM A. RICHARDSON-Color, rich coppery Jellow, flushed with carmine; a very beautiful variety, having few equals.

DUCHESS D'AUERSTADT-Same type as Marechal Neil a little deeper in color and much more hardy; a splendid yellow climber. 


\section{The Famous Rambler Roses}

The Rambler Roses are strong, vigorous climbers, growing ten to twelve feet high in one season. They bear immense clusters of beautiful, fragrant flowers.

We specially recommend Flower of Fairfield and Dorothy Perkins. noted.

Price: 1 yr., 15c each. Any four sorts, 50c. Two-year-old plants, 35c each, except where

THE BLUE ROSE-This is the new rose Vellchenblau or Violet Blue that has attracted so much attention in Europe, and is the first rose of its color ever produced. Violet Blue is a vigorous climber of the polyanthus type, flowers medium size, semi-double, borne in large clusters; color on opening is a rosy lilac, quickly changing to a metallic blue, has splen did foliage of a rich green color that does not mildew Choice field grown plants now ready. Fach, 50c

FLOWER OF FAIRFIELD-Everblooming crimson rambler, brilliant crimson, base of petals white, flowering in great profusion perpetually throughout the season. Flower of Fairfield is a true, everblooming, Crimson Rambler, a splendid grower and a great improvement over the old type; strong field grown plants. Fach, 50c

DOROTHY PERKINS-Polyanthus type; color a beautiful bright shell pink, flowers large, very double; petals prettily crinkled; blooms in large clusters of 30 to 40 ; remain in perfect condition.

PHILADELPHIA RAMBLER-An improved type of the old favorite Crimson Rambler; color, deeper, more brilliant and lasting; flowers perfectly double, borne in great profusion, much earlier than the old type; vigorous, luxuriant foliage, not susceptible to mildew.

WHITE RAMBLER-Flowers pure white, sometimes faintly tinged blush, flowers borne in immense clusters; very vigorous.

YELLOW RAMBLER-Same type and growth as Crimson Rambler, except for color, which is a pure, bright yellow.

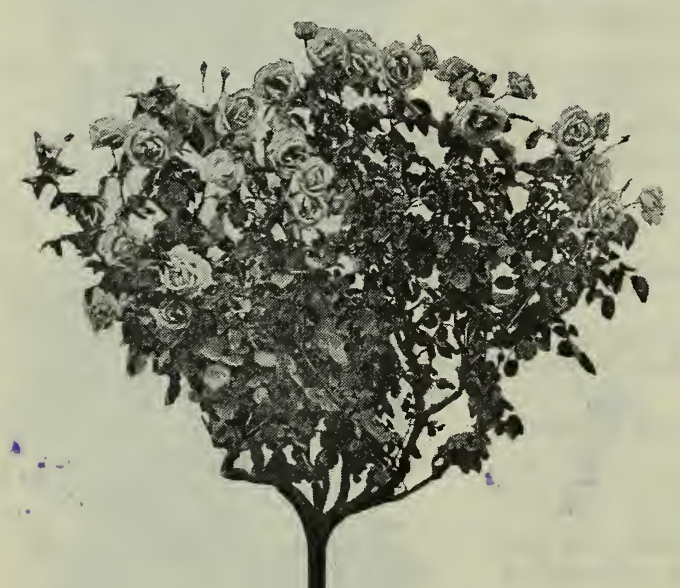

No. 5 is the Best Fertilizer for your Lawn and Roses.
Standard, or Tree Roses

Price of all Tree or Standard Roses, $\$ 1.50$ to $\$ 2.00$ each, according to size of head. Tree roses are budded or grafted on hardy rose stocks about four feet high. They soon make good sized heads forming a small tree, especially desirable for planting as single specimens, in backgrounds or rows along walks or driveways.

Order any color or variety you wish and we will send it or give you as good a substitute as possible. We aim to have the following varieties in stock: La France

K. A. Victoria

Conrad F. Meyer

Countess of Gasfori

Ulrich Brunner

Grus an Teplitz

F. K. Druschki

Baby Rambler Richmond

Baroness Rothschild

Gen. Jack

\section{Moss Roses}

Dorothy Perkins

Glorie de Dijon

Gen. McArthur

Marechal Neil

Mad. Abel Chatenay

Mad. Gabriel Luizot

Wm. Allen Richardson

These old-fashioned Roses are coming into favor and we offer the following as best of their colors. Price, each, 35c; dozen, $\$ 3.00$. BLANCHE MOREAU-Flowers pure white,

large, sweetly perfumed; borne in clusters. Best white moss rose.

CHAPEAU DE NAPOLEON-Splendid rich red, best of its color

CRESTED MOSS-Bright rose, light edging, well mossed.

SAIET-Color, beautiful satin rose; very full and of great beauty; one of the best.

\section{P. S. Co.'s APHISCIDE}

The Best Summer Spray for ROSES

Prices, Qts., 25c; Gal. 65c. Ready for use.

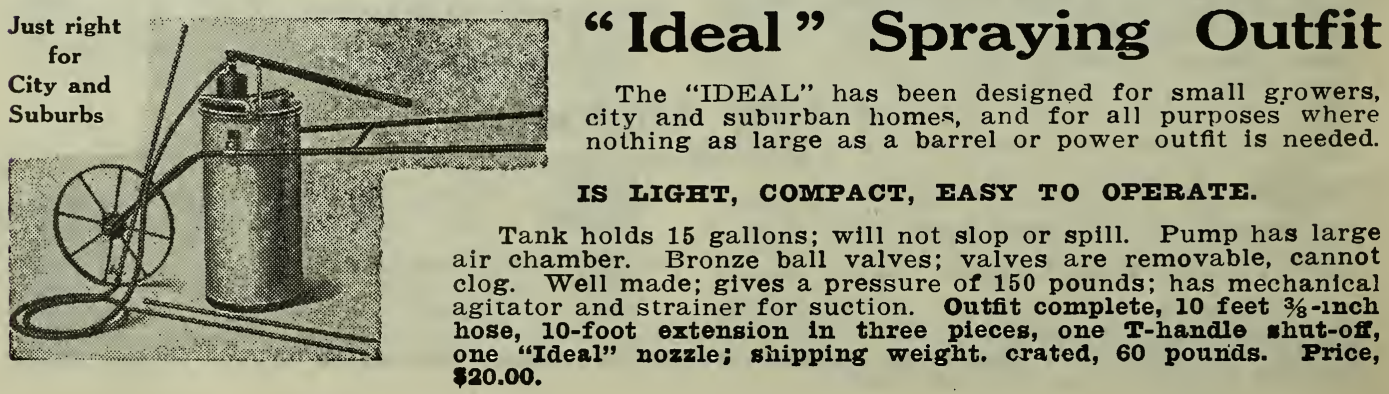




\section{Alphabetical List of Roses \\ rice $\mathrm{Po}$}

Name and Class, Aards Pillar, H. T. American Beauty, $\dot{H}$. $\dot{P}$ Anna de Diesbach, H. P Anna Olivier. T.

Baby Rambler, Poly. Baroness Rothschild. H. i’ Belle Siebrecht, H. T. . Bessie Brown, H. T. Betty, H. T.

Bridesmaid, $\mathrm{T}$.

Blue Rose, Poly.

Cilpt. Christy, H. P

Cecile Brunner. Polr.

Chat. de C. Vougeot. H. T. Com. J. Graveraux. H. T... Conrad F. Meyer, Rug..

Climbing Roses

Countess of Gosford, H. T.

Dean Hole, H. T.

Doroths Page Roberts, $\dot{H} . \mathbf{T}$ Dorothy Perkins, Poly. Duchess de Brabant. T..... Duchess of Portland. H. T. Ducbess of Albanr. H. T... Elizabeth Barnes, H. T . Etoile de France, H. T. Etoile de Lron, T.... Friedrichsruh, T.

Friedrichsruh, T. … $\dot{H}$. Framze Deegan, H. T. . . F. K. Druschki, H. P. . Flower of Fairfield, Poly. Gen. McArthur, H. T. Gen. Jacqueminot, $\mathrm{H}$. P Gloire Lronnaise, $H$. T. . Harr Kirk, H. T... Harr Kirk, H. T...

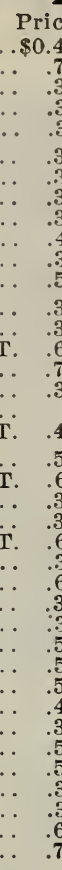

\section{Name and Class.}

$\begin{array}{ccc}40 & 41 & \text { Hon. Ina Bingham, H. T... } \\ 75 & 36 & \text { Hugh Dickson, H. T....... }\end{array}$

3540 Irish Elegance, $\mathrm{S}$.

40 Irish Harmony, $\mathrm{S}$

$\$ 540$ J. B. Clark, H. T.

3540 Jonkheer J, H. T.... H. .40

3540 Joseph Hill, H. T..........

$\begin{array}{lll}40 & 39 & K \\ 35 & 40 & K \\ \end{array}$

5042 Lady Alice Stanles, H. T...

54 Lady Hillingdon, T....

35 Lady Battersea, $\dot{H}$. T.

La Detroit, H. T.

55 La France, H. T.

39 Le Progress, $\ddot{H}$. $\ddot{\mathrm{T}}$

5038 Liberty, H. T.

\begin{tabular}{ll}
60 & 37 \\
\hline & 42
\end{tabular}

42 Mme. Phil. Reroire, $\ddot{H}$. 'T.

Marquise De Sinetr, H. T.

Mme. Segond Webber,

IIme. Leon Pain, $H$. $\mathrm{T}$.

Ime. Melanine Soupert. $\ddot{H}$. $\dot{T}$.

Mme. C. Testout, H T.

Mme. Francisca Kruge

Mam. Cochet, T.....

Mabel Jorrison, H. P.

Margaret Dickson, $H$. $\mathbf{P}$

Marie Van Houtte, T.

Molly Sharman Crawford, $T$.

Mrs. Aaron Ward. H. T.....

Irs. A. R. Waddell, H. $\mathrm{T}$

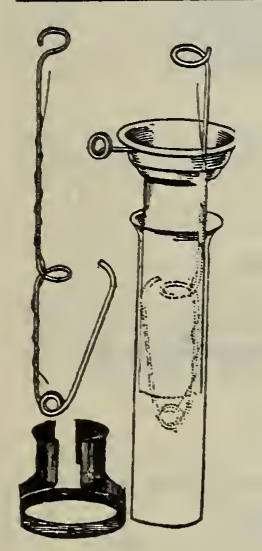

\section{Foster Rose Tubes}

\section{For Rosarians and Cut Flower Exhibitors}

FOR SHOWING ROSES

The Foster Exhibition tubes with adjustable clips, enable you to transfer flowers from one position to another without disturbing their arrangement. A wire holds the flower firmly in any desired position. Tubes afford an ample supply of water close to the rose.

Used at all English shows. Price, each, 35c; doz., \$4.00.
.50
.58 Mrs. Harold Brocklebank, H.

\begin{tabular}{llllll}
50 & 37 & Mrs. David Jardine, H. T.. & .75 & 36 \\
\hline
\end{tabular}

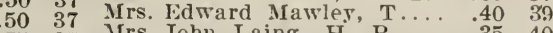

$75 \quad 37$ Mrs. John Laing, H. P.

$40 \quad 39$ ford, H. P. .......... 35 4n

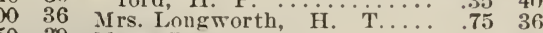

inoss Roses

is $s$ Maryland, H. T...............

40 Papa Gontier, T.............35 40

6 Panl Neyron, H. P...........3. 40

9 Prince de Bulgarie, H. T. . $.40 \quad 39$

Prince . Barie vertscher-

. 39 Pross

39 perlo des

Rason Dor Pes,

Rhea Reid, H. P.

Richmond, $\mathrm{H} . \mathrm{T}$.

9 Rrmblers

Souv de C. Guillot, T

Soliel D'Or, Pern.

Safrano, T. Pa..........

39 Souv. de Pres. Carnot, H.T

40 The Bride, T. Carnot. H.T.

40 The Bride,

40 Tree heses.

40 Virich Brunner, H. P...... 40

40 Viscountess Folkstone, H.T

40 White Maman Cochet. T..

White Killarner, H. T. .

Wm. Shean, H. T.

White La France, H.

Wm. R. Smith, T...

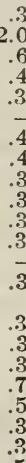

$.35 \quad 4 n$

\section{Flower Pots}

We are agents for the Garden City Red Clay Pots and buy in carload lots. The wholesale trade, florists and nurserymen are requested to send for special prices, stating quantity wanted. They are by far the finest pots offered on this coast.

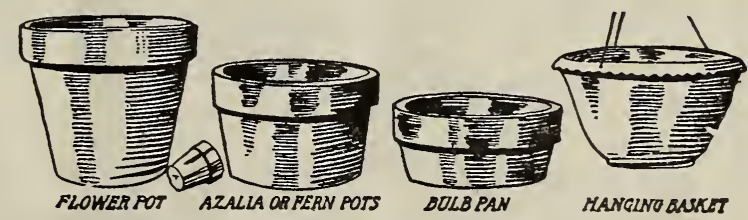

FLOWER, FERN, AZALEA POTS OR BULB PANS (AII SAME PRICE).

Roses received. Thank you very much. I wish to say that I appreciate you way of doing busi ness. I purchased "Gold Dollars" of you last have seen. You may depend on my orders in your line in the future.

Bay City, Ore.,

Dear Sirs: I wish to thank you and tell you how well pleased we were with the condition and promptly.

you came in perfect condition. thanks for the extra plants, which I was pleased to get.
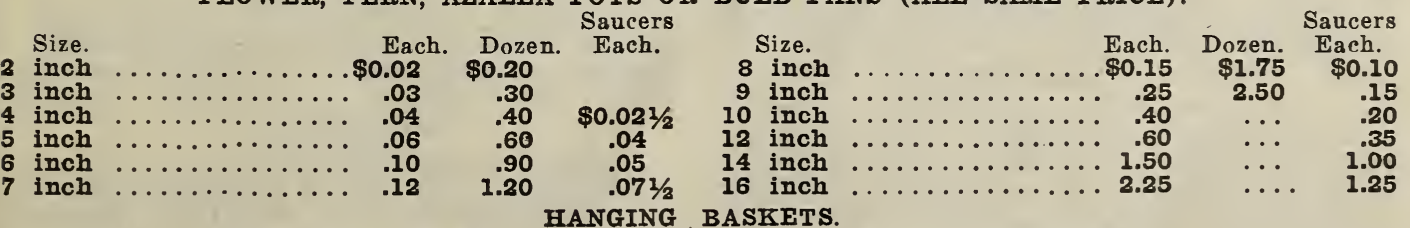

These are well made, having scalloped edge and fancy designs on the lower outside. Better than wire baskets, as plants do not dry out so quickly.

8-inch... Fach, 30c; doz., \$3.40 10-inch. .Each, 40c; doz., \$4.00 12-inch..Fach, 60c; doz., \$7.00

NOTE-At above prices we will pack the pots carefully, but buyer must pay freight or express charges. We buy in carload lots and the wholesale trade, florists and nurserymen are requested to send for special prices, stating quantity wanted.

PAPER FLOWER POTS FOR FLORISTS

Low in price, Molsture Proof, Unbreakable, Light, Convenient.

100.1000

$21 / 2$ inch

100.

$\$ 5.50$

$3 \frac{1}{2}$ inch 


\section{Fruit and Ornamental Trees Shrubs and Plants}

Deliveries can be made from October until June, but orders are accepted at any time for delivery in Season.

PLANTING AND CARE OF STOCK

W

U use every precaution to deliver healthy, vigorous stock, but the measure of your success will depend upon the planting and care given, as careless or ignorant handling kills thousands of fine trees and plants every season. Avoid unnecessary exposure of roots to the air. In the case of evergreens that are "balled," do not remove the burlap. Plant as received, only cut the string around the top, then loosen the burlap after the tree is set. If you cannot plant immediately on receipt, always "heel" in the trees so their roots may be in contact with good soil. An hour's exposure of roots to wind or sun may kill any tree; this is especially true of evergreens. In planting cut off the bruised or broken roots with a sharp knife.

If the soil is good and properly prepared, only a hole large enough to easily take the roots need be dug, but better results can always be obtained by digging out a large space and filling in with good top soil. In setting the trees, do not put deeper than they stood in the nursery, excepting some dwarfs, which go a little deeper. But now comes the important detail, the neglect of which is responsible for many failuresBe sure to pack the earth solidly around the roots. Leaving the ground loose after planting has caused tremendous losses that are generally and unjustly blamed to the nurseryman. Another cause of great loss is the wind working the newly set trees loose from the soil. This kills them. Always stake newly set trees if in a windy situation. After trees are set, make a plan of the grounds, marking the different varieties, then remove the wire labels, as they may damage the growing limb.

\section{KEEPING TREES OVER WINTER FOR SPRING PLANTING}

This can easily be done by following the simple instructions given below:

Select a well-drained spot where the soil is mellow, and dig a trench deep enough to cover the roots well: put in one layer of trees, placing them so they will not be erect but at a decided angle: pack the dirt firmly about the roots, then place the next layer. When trees are all "heeled" in, cover the tops with boughs or bank up the earth over them. Be sure there is no grass or rubbish near to harbor mice. In mild situations where winters are not severe, do not bury or cover the tops; simply "heel in." Trees thus kept are on hand ready for planting as soon as the frost is out of the ground and will be found well preserved and are more sure to grow than later spring planting. Besides, you get better service by ordering in the early fall as stocks are more complete.

If trees are frozen in transit, do not unpack, but set away in a cool cellar and allow them to thaw gradually. Trees or roses that are dried out and shriveled should be buried, tops and all, in moist earth for a few days. This will restore them.

SEE PLANTING TABLES INSIDE BACK COVER

\section{Tree and Plants Delivered in Perfect Condition}

\section{READ THESE UNSOLICITED REPORTS
FROM NEW ZEALAND}

\section{FINEST APPLE TREES}

Gentlemen: The apple trees that I got from you last spring are the finest trees I ever saw. All my neighbors are very liberal in their praise of them also. You will sure get my future orders and also a good many of my neighbors.

\section{"LAMBERTS"}

Gentlemen: Again referring to ours of July 17, the cherry trees sold Mr. Grosbeck. Mr. Grosbeck was in the store again this morning and reports that he has the finest lot of fruit that a person ever got off from trees.

\section{FROM IOWA}

Chillicothe, Iowa, May 23, 1911.

Gentlemen: I received the last collection of roses sent me in good condition. I was well pleased with them. Any order that I can send you in the future I will be glad to do so.

\section{NFW HAMPSFIRE.}

Manchester, N. H.

Gentlemen: Just received your plants today in as good order as if plants had been just dug up. If I get more plants from you, send them by freight, for if you pack them as they were they will keep for weeks.
Gore, Southland, N. Z., July 6, 1911

The apple trees I got of you for shipment to New Zealand arrived in good condition and are all growing splendidly.

\section{FROM MISSOURI}

Anabel, Mo., May 7, 1911.

I want to thank you for the condition of the roses you sent. They arrived in superb condition, were packed splendidly and were planted as soon as received and are making a grand growth. I never got roses before that were so healthy and thrifty and am surprised that they could be so perfectly packed to come so far by mail. Yours truly,

\section{FROM TEXAS}

Beaumont, Texas, February 15, 1911.

Dear Sirs: The plants arrived in splendid shape and certainly hope they will do well here.

\section{FROM NEW YORK.}

Mt. Vernon, N. Y.

Gentlemen: It gives me pleasure to state that the Loganberry and Strawberry plants shipped me arrived in good condition yesterday, and I wish to thank you for your prompt attention. 


\section{FRUIT STOCK}

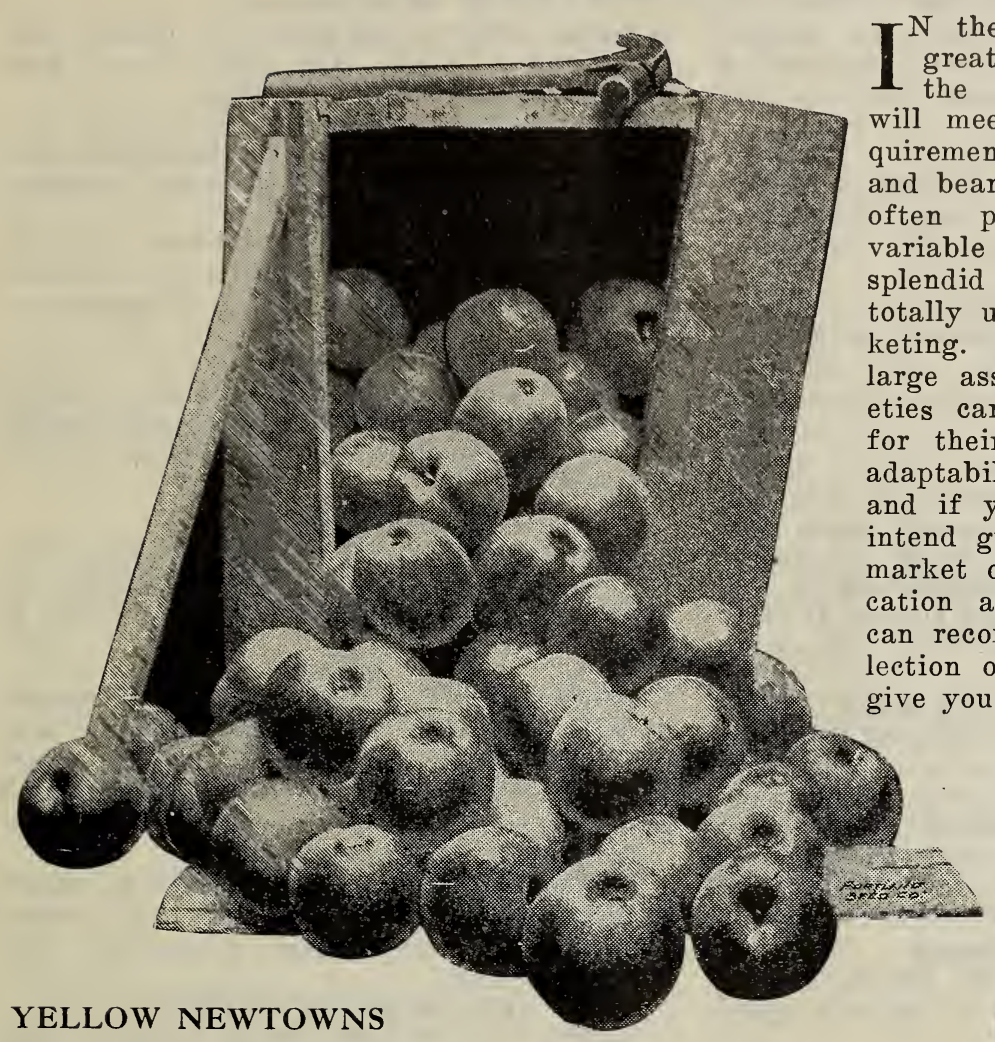

APPLES

Prices of standard commercial varieties except where noted:

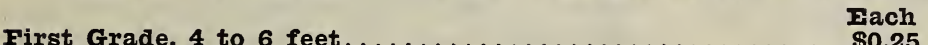

Second Grade, $\mathbf{3}$ to 4 feet. . . . . . . . . . . . . . . . . . .20

\section{SUMMER VARIETIES}

\section{EARLY HARVEST}

Medium size; bright straw color; tender and fine; good tor table and cooking. July.

\section{GOLDEN SWEET}

Large, pale yellow, tender and rich; good for cooking; fine bearer. August.

\section{GRAVENSTEIN}

Large, beautifully dashed with deep red and orange; tender and crisp, with a highly aromatic flavor; tree very vigorous. August.

\section{DWARF FRUIT TREES} make profitable "fillers" for young orchards and are best for Home Gardens. Our stock is largevarieties and quality the finest. (See page 48.)

\section{AUTUMN VARIETIES}

RAMBO

Medium, yellowish white, streaked yellow and red; tender, rich and sub-acid; very productive. September to November.

\section{WAXEN}

Fruit medium; skin pale yellow; flesh crisp, tender, juicy, sharp acid; one of the best for drying. October.

\section{FAII PIPPIN}

Yellowish green; good cooking apple. September.

\section{MAIDEN'S BLUSH}

Medium, well shaped; yellow, with a very distinct red cheek on the sunny side; flesh white; pleasant sub-acid flavor; excellent for table or cooking. September.
Medium, oblong, deep red; excellent for table use; one of the best early apples.

\section{RED ASTRACHAN}

Large, deep crimson, flesh white, moderately juicy, with an agreeable rich acid flavor; very productive. August.

\section{YELLOW TRANSPARENT}

Medium size, roundish, slightly conical; skin pale yellow; flesh tender, juicy, subacid; good; bears at an early age. July.

\section{TWENTY OUNCE}

Large and showy; good, though not highly flavored; flesh coarse, brisk sub-acid. October.

(Snow Apple.) PAMEUSE yellow, with streaks of deep red on sunny side; flesh remarkably white; fine dessert fruit. October to December.

\section{GOLDEN RUSSET}

Medium, dull russet, with a tinge of red; flesh crisp, juicy and highly flavored. September.

GIORIA MUNDI
Large green, fine sauce apple. Last of September. 
ARKANSAS BLACK

Medium, round; yellow where not covered with a beautiful dark maroon, approaching black; flesh firm, fine grained, juicy; a long keeper. December to April.

\section{BALDWIN}

Large, rounded; deep, bright red; very productive; crisp, fine flavor; one of the best and most popular winter apples. November to February.

Medium to large; yellowish, overspread with red; flesh white, tender, juicy; pleasant sub-acid; thrifty, upright grower. October to January.

(Delaware Red). LAWVER sub-acid, very heavy and hard; dark red; handsomest late keeper. December to May.

ORTLEY, OR WHITE BELLEFLOWER

White fleshed, fine grained conical fruit of superior flavor; one of the best. December to April.

\section{HYDE'S KING OF THE WEST}

Large to very large; handsome yellowish green; good quality; a remarkable keeper; a very popular sort in some sections. November. ROXBURY RUSSET

Medium, dull green and russet; flesh greenish white, rich sub-acid flavor. October to January.

\section{RED CHEEK PIPPIN}

Excellent variety; sub-acid flavor; yellowish green color; red cheek; large size; good bearer. Keeps till March.

\section{SPITZENBERG}

Large, oblong; yellowish ground with broken stripes of bright red; flesh yellowish, juicy, delicious rich flavor. November to March.

\section{YELLOW BELLEFLOWER}

Large, oblong, yellow, sometimes a blush in the sun; flesh firm, crisp, juicy, sub-acid; tree a good crower and very productive; succeeds well in this valley. October to January. KING

Large and handsome, striped red and yellow: tree vigorous and productive. November to December. Good mountainous apple.

\section{JONATHAN}

Tree vigorous, long lived and an early bearer. Fruit beautiful red and oblong; fine quality. Valuable as a pollenizer with Spitzenberg and Newtown. October to January. MAMMOTH BLACK TWIG

Very large; bright red, pleasant sub-acid; fine late keeper; fine, vigorous tree. November to January.

\section{NORTHERN SPY}

Large, round, greenish yellow, stripes of purplish red; flesh white, juicy. brisk subacid; valuable for "'top work.', Requires good soil. December.

\section{MCINTOSH RED}

A seedling of the Fameuse; bright red, flesh white, very tender and delicious. Long lived and very productive. Adapted to Montana. November.

\section{RHODE ISLAND GREENING}

Large, greenish yellow; flesh yellow, fine grained, tender, crisp, juicy and aromatic; excellent for cooking and table. October.
ROME BEAUTY
Large, yellow, shaded with bright red; juicy and sub-acid; fine market sort; good bearer. November to February.

\section{WEALTHY}

Medium, whiteish yellow, shaded with deep red; flesh white, tender and juicy. October. WINESAP

Medium yellow ground, streaked with red; flesh yellow, with rich, high flavor; excellent for table and making cider. December to April.

Large and handsome; greenish yellow shaded with dark and light red; tree a strong grower and good bearer. September to November.

\section{WAGENER}

Good size; deep red in the sun; flesh firm and fine grained; good keeper; sub-acid; excellent filler; requires thinning. October to December.

\section{STARK}

Large, greenish yellow, shaded and splashed with dark red; flesh yellowish, juicy, mild sub-acid; a long keeper and profitable market fruit; thrives in California. December to March.

Medium size, pale, whitish yellow, tinged with red; flesh firm; rich and very sweet; best to preserve; vigorous, productive. November to April.

\section{YELLOW NEWTOWN PIPPIN}

Large; skin smooth, golden yellow; flesh firm, crisp, juicy; one of the standard varieties for export. December to May.

\section{GRIMISS GOIDEN}

Very popular. Rich golden yellow; flesh tender, juicy and rich. Tree hardy and vigorous, bearing young. November to December.

DFIICrous
A splendid apple; coming into prominence rapidly. Tree vigorous and hardy and the fruit equals the name in every respect. Fine for market and home use and especially adapted to Eastern Oregon and Washington. Keeps till April.

\section{STAYMAN WINFSAP}

A seedling of the Winesap. Yellow striped with red. Flesh firm, crisp, juicy and very tender and rich, sub-acid. A drougth resister; a profitable market variety. January, May.

\section{IADY APPIT}

A novel, dainty, small flat apple; red cheek. Good Christmas fruit. Tree upright and vigorous.

A cross between Jonathan and Arkansas Black. Color deep, rich red. Tree a young and heavy bearer. November to March.

\section{SAIOME}

Early and annual bearer; very hardy; fruit medium and uniform; quality good. November.

\section{GANO}

Fruit is a bright red on yellow ground, large oblong, smooth. Tree vigorous and prolific bearer. Fine keeper. November to April. 


\section{NEW VARIETIES OF APPLES}

\section{Note prices following each variety. Nice stocky trees.}

\section{WINTERSTEIN}

A winter apple of the Gravenstein type; flesh yellowish, very tender, rich, spicy, subacid, highest quality, with a flavor all its own.

Price, each, 60c

\section{OPALESCENT}

Probably the handsomest apple ever introduced. Color light, shaded to a very dark crimson; skin smooth; susceptible of a very high polish reflecting objects like a mirror; flesh yellowish, tender, juicy and good.

Price, each, $60 \mathrm{c}$

\section{MULTNOMAH (New)}

A grand new sort; a hybrid between the American Pippin and Rome Beauty. Originated by H. A. Lewis. Fruit large; color red, striped yellow; flesh white and fine and of sub-acid flavor; extra long keeper and in its prime from February to June; the coming apple for long distance shipment and Oriental trade.

Price, each, 60c
ONTARIO

A cross between Wagener and Northern Spy. Fruit large to very large; flavor a brisk sub-acid, sprightly, slightly aromatic; season mid-winter to late. Price, each, 60c

\section{CLAYTON}

Winter; large, yellow, striped red; productive. December to January. Price, each, 35c BISMARCK

The apple novelty; everyone should try it; tree of short, stocky growth, thick, healthy foliage; fruit large, handsome, yellowish sometimes shaded red cheek; flesh tender, pleasantly sub-acid; entirely new; seldom failing to bear when two years old. September.

Price, each, 35c

\section{WINTER BANANA}

Fancy market fruit; pale yellow with pink blush. Has a delightful aroma and suggestive banana flavor. Not a good shipper. November.

Price, each, 35c.

\section{CRAB APPLES}

FIORENCE

Nice stocky trees, each, 35c; per 10, $\$ 3.00$
Large, handsome; red striped; early; good annual bearer, juicy and crisp; fine for the home garden. September 1.

\section{MARTHA}

Glossy yellow, shaded to red; fine for cooking and fair for eating fresh; tree handsome, vigorous and hardy. September.

\section{TRANSCENDENT}

Very large, pleasant flavor and good for cider; yellow striped red. Very productive. Adapted to Montana. September.

\section{YELIOW SIBERIAN}

Fruit small, fine golden yellow. Good. August.

HYSIOP
Large, deep crimson; tree hardy, fine for the West. November, January.

\section{RED SIBERIAN}

Yellow with scarlet cheek. Bears young and abundantly. September.

\section{WHITNFY NO. 20}

Tree thrifty, upright grower. Fruits large, striped; flesh firm and juicy. Very good. August.

\section{APRICOTS}

\section{Prices except where noted:}

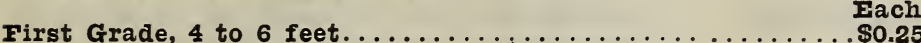

\section{THE LEWIS}

The new Lewis Apricot is the largest, strongest growing, best vieldiny, best flavored apricot we have ever seen, and is perfectly hardy. Grown extensively in the "Goodnoe Hills' district. July, August.

Special prices in large lots. Price, each, 75c

\section{MOORPARK}

Very large, yellowish green, brownish red on the sunny side; flesh bright orange; fine for canning and drying; freestone. July, August.

\section{Per 10 Per 100 Per 1000 $\$ 2.25 \quad \$ 20.00 \quad \$ 180.00$ ROYAI}

Above medium size; sweet, rich, juicy; good dryer and canner. July.

$$
\text { TILTON }
$$

Large; rich color, high flavor; very productive; similar to Royal; later. July.

\section{BIFNHEIM}

Deep orange, sometimes blushed; tender, rich and juicy. Tree vigorous. Good for Pacific Coast. Last of June.

\section{HFMSKIRKE}

Large, flesh bright orange; tender, plum like flavor. July.

\section{NECTARINES}

\section{BOSTON}

Large, deep yellow, bright blush; flesh yellow; very rich and luscious. Best for Oregon. August 1 .

\section{FARIY VIOLET}

Medium; skin pale, shaded violet; flesh white; good. July. 


\section{DWARF TREES}

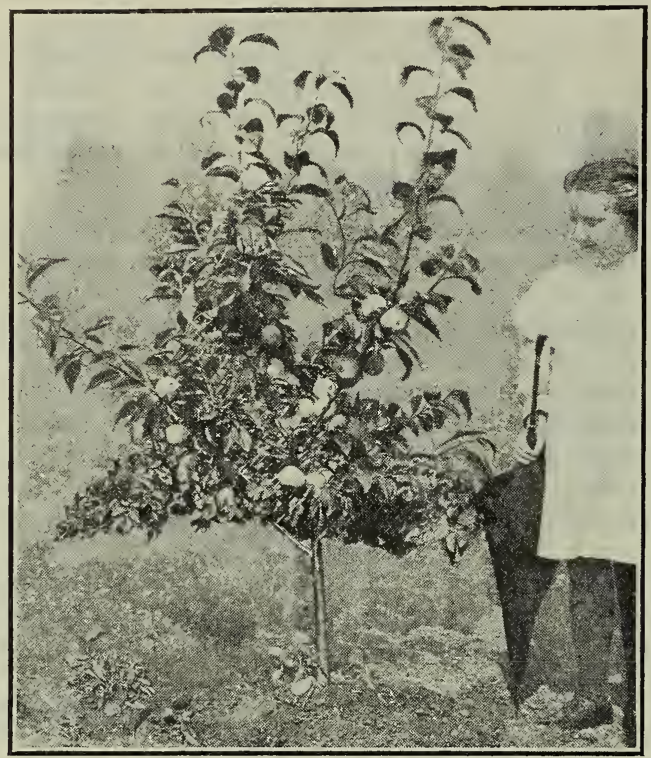

These are ideal for home gardens; come into bearing early and yield large crops of choicest fruits. Forty Dwarf Trees can be planted in a space 50 feet square and will not shade the ground, which can be cultivated between the trees. For best results Dwarf Trees must be planted in good rich soil and be well cared for; they should be pruned back about twothirds of their new growth each spring.

DWARF APPIES

$\begin{array}{ccc}\text { Baldwin } & \text { Jonathan } & \text { Spitzenberg } \\ \text { Red Astrachan Gravenstein } \\ \text { Bismarck } & \text { Rome Beauty } & \text { Wealthy } \\ & \text { Yellow Transparent } \\ & \text { DWARF PEARS }\end{array}$

Bartlett Fall Butter

Beurre de Anjou L. B. de Jersey Shelton

Price, cach, 50c; $10, \$ 4.00 ; 100, \$ 35.00$

"THE AMERICAN APPLE ORCHARD" (Waugh)

214 pages, Postpaid, $\$ 1.15$

A Standard Authority

\section{CHERRIES}

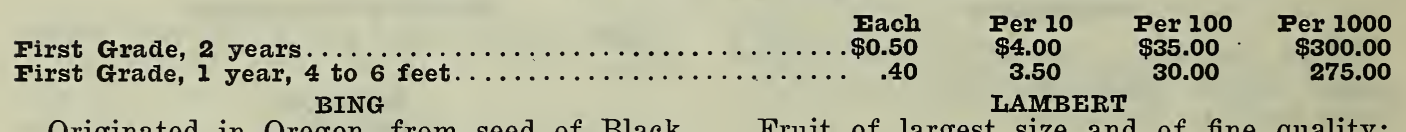

Originated in Oregon, from seed of Black Republican; fruit large, dark brown or black; very fine; late; a good shipping variety. July. BLACK REPUBLICAN (Lewelling)

Seedling, raised by Set $\mathrm{L}$ Lewelling, of Oregon; large size, black, sweet, with purplish flesh; late and a good shipper. June. KENTISH (Early Richmond)

Dark red, juicy; onc of the best sour cherries and unsurpassed for cooking purposes; very productive. Mid-May.

\section{IATE DUKE}

Large, light red; late and excellent, sub-acid. Late July.

\section{. OREGON}

Large, black, solid, free, vigorous and productive; a fine shipper. July.

\section{ROYAL ANN}

(Napoleon Bigarreau.) A magnificent cherry of the largest size; pale yellow, becoming amber in the shade; richly dotted and spotted with deep red, and with a bright red cheek; flesh very firm, juicy and sweet; tree a rapid grower and immense bearer. Judy 1 .
Fruit of largest size and of fine quality; color deep, rich red; flesh firm and of fine flavor; a fine market variety; ripens two weeks later than Royal Ann. Mid-July.

\section{MAY DUKE}

Large, rich, dark red; flesh tender, juicy and sub-acid; an excellent variety, and one of the earliest of its class. May.

\section{MILLER'S LATE}

This new cherry resembles the Late Duke in color, shape and flavor, but it is a larger and later variety, which makes it very valuable and desirable. August. Price, each, 60c NEW GIANT

Claimed by the originator to be equal in every way to the famous Lambert, but to possess the good points of being a larger and later cherry. A strong, vigorous grower; heavy cropper.

Each, \$1.60; large trees, $\$ 1.50$ ROCHALINE (New)

A new German cherry, larger and redder than the Royal Ann; better shipper and more prolific bearer. July.

Each, 60c

Prices except where noted:

\section{QUINCE}

First Grade, 4 to 6 feet.........

Large, yellow; flesh cooks very tender; flavor is most delicious; more productive than the Orange. October.

\section{APPIE OR ORANGE}

Well known standard variety; early; large, golden yellow; good for preserving or flavoring. September.
Per 10 Fach PINEAPPLE

Flavor is suggestive of the pineapple; the fruit resembles the Orange quince; making

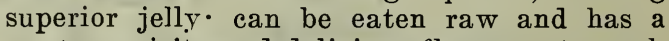
most exquisite and delicious flavor, not equaled by any other quince. September.

Price, select, 1 year, 50c; 2 years, 75c. 


\section{PEARS}

First Grade, 4 to 6 feet, 1 year........................ $\$$. $\$$.

Second Grade, 2 to 4 feet, 1 jear. . . . . . . . . . . . . . . . . 50 at hundred rate -500 at thousand rate.

\section{SUMMER VARIETIES}

\section{BARTLETT}

Large; skin thin, clear, lemon yellow, with soft blush on the sunny side; flesh white, buttery, very juicy and highly flavored; the best summer pear in existence. August, September.

\section{SECKEI}

Rich and highly flavored; its highly concentrated, spicy, honey flavor is unequaled; skin brownish green, russet brown cheek; flesh whiteish, buttery and melting. September, October.

\section{AUTUMN VARIETIES}

BEURRE BOSC

Large, beautiful, russety; highly flavored; fine for shipping. September.

\section{LOUISE BONNE DE JERSEY}

Large, grenish yellow, brownish red in the sun, marked with gray dots; flesh juicy, melting; very prolific. October.

\section{BEURRE CLAIRGEAU}

Large, yellow, shaded with orange and crimson; covered with russet dots; flesh yellowish, buttery, juicy. September.

\section{BEURRE D'ANJOU}

Large, handsome, fine flavor; tree vigorous; heavy bearer; keeps till Christmas. September.

\section{WINTER VARIETIES}

ROOSEVELT (New)

Size very large, shape roundish. Flesh fine texture, juicy, melting. Ground color yellow, clouded with salmon rose. Season October.

\section{IINCOIN COREIISS}

Price, each, $75 \mathrm{c}$

Practically coreless; very late. Fruit should be picked when green. Large, quality good. Fairly hardy and good bearer.

\section{CROCKER BARTIETT (New)}

In shape, oblong, large and of a rich golden color. Skin rather thick but tender; flesh yellowish, buttery, juicy, sub-acid to sweet and very rich. Tree very vigorous, so far unblighted. October. Price, each, 50c; per $10, \$ 4.50$.

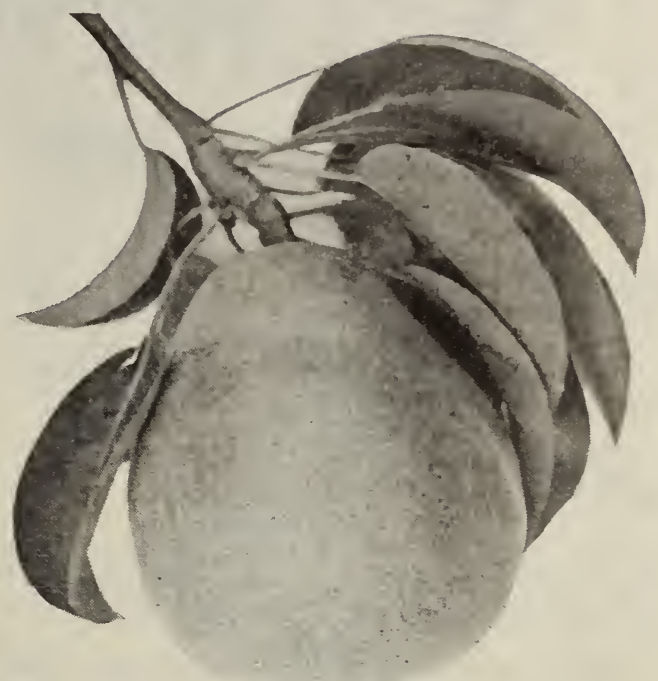

See page 48 for DWARF PEARS.

COMTCE

A splendid commercial variety, being of fine size; good appearance; ships well. October.

\section{FALL BUTTER}

A favorite fall pear; yellow, sweet and juicy. September.

This fine pear originated in Eugene, Oregon. Fruit large, closely resembling the famous Bartlett in shape and appearance, but ripening considerably later; flavor almost identical with the Bartlett; is undoubtedly one of the few pears of recent introduction of real merit. Price, each, 50c; per 10, $\$ 4.50$. BUERRE EASTER

Large, oval, yellow, with red cheek; excellent winter pear; February, October, January. WINTER NELIS

Medium; skin yellowish green, dotted with gray russet; flesh yellowish white; fine grained, of a rich saccharine, aromatic flavor. December.

\section{PRUNES}

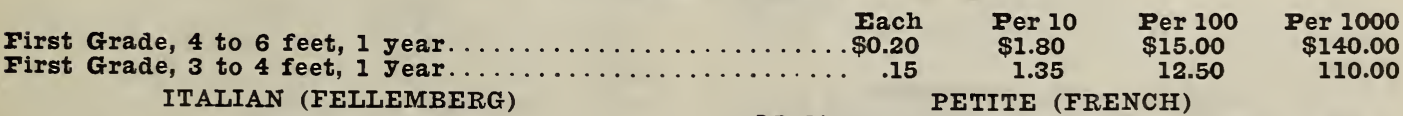

Large, oval, tapering at both ends; dark purple; flesh greenish yellow; separates freely from the stone; best for drying. August.

\section{SILVER}

Seedling of the Coe's Golden Drop; tree vigorous and productive; fruit large and superior; excellent for drying or canning. September.
Medium, egg shaped; violet purple; sweet, rich and sugary; very productive; standard variety for drying. August.

\section{GIANT}

Largest prune known; fruit areraging 11/2 to 2 ounces each; retaining the good qualities of the smaller varieties.

Very large; dark red, juicy and sweet; good shipper. August.

\section{HUNGARIAN}




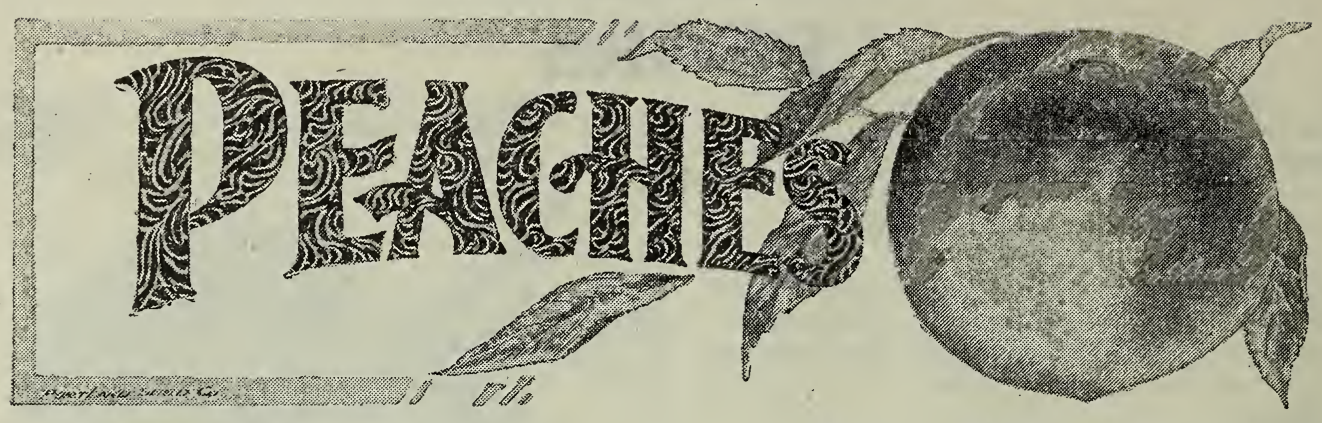

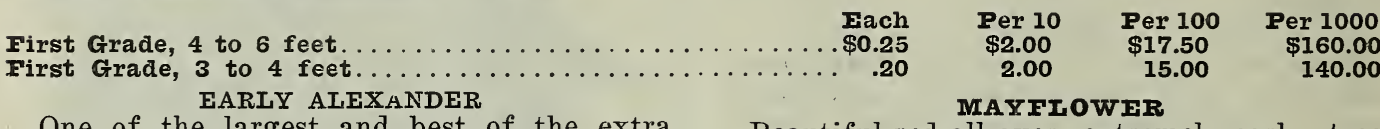

One of the largest and best of the extra early varieties. Almost freestone. July. EARLY CHARLOTTE

Hardy, medium early, excellent flavor; originated in Oregon. Freestone.

EARLY CRAWFORD

Very large, yellow, with red cheek; flesh sweet and excellent; our most popular peach for table and canning; freestone. August.

\section{ELBERTA}

Very large, bright yellow, red cheek; flesh yellow; juicy, sweet; regular bearer; fruit very showy and perfect; freestone. Late July. FOSTER

Large yellow, dark red on the sunny side; very rich, juicy and early; freestone. Late July.

\section{IATE CRAWFORD}

Very large, roundish; yellow, with dark red cheeks; flesh deep yellow; juicy and melting; flavor rich and excellent; freestone; valuable for canning and drying. September. MUIR

Large, pale yellow; very firm and sweet; best for drying; freestone. August.

Beautiful red all over; extremely early; tree hardy and healthy. Should be in every home and commercial orchard. Last of June. Free.

CHAMPION

Large, cream white, slightly blushed. Tree hardy; should be in every orchard. July. Free.

\section{IIEATH'S CIING}

One of the best of the clings. Very large; creamy white, with slight red; flesh white. September.

Very large; yellow, blushed red. Vigorous and strong grower. July and August.

\section{CROSBY}

Medium; rich orange with slight red blush; freestone, pit small, flesh yellow, sweet and juicy. Good shipper; rank grower. Ripens before Crawfords Late.

\section{KRUMMEIT OCTOBIRR}

A magnificent peach; very profitable. Ripens two weeks after Salway, but far better; a good keeper. Free from bitterness, very firm and fine texture. Tree vigorous, hardy. Good for State of Washington. Free.

\section{PLUMS}

Prices except where noted:

\section{First Grade, 2 jears}

First Grade, 1 jear, 4 to 6 feet.

\section{ABUNDANCE}

Fruit large and beautiful; bright cherry; flesh light yellow; juicy, tender; sweet; productive; freestone. June.

\section{BRADSHAW}

Reddish purple, juicy and pleasant; adheres partially to the stone. July.

\section{COLUMBIA}

Largest size, nearly globular; brownish purple; rich, sugary, freestone. August.

\section{DAMSON}

Small, oval, bluish purple; flesh melting, rather tart. Tree very fruitful and hardy. August.

\section{DAMSON-SHROPSHIRT}

Medium size, dark purple; very firm; flesh greenish, juicy and rich. Vigorous. Late September.

\section{SATSUMA (Blood Plum)}

Quite popular; large, dark red from skin to pit, which is small, firm and juicy; tree productive. Early July.

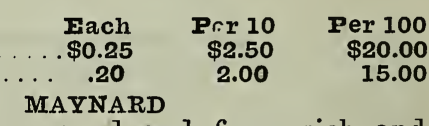

Dull red, large, round and firm; rich and sweet; sturdy, quick-growing, heavy-yielding variety; extra fine; ripens in July. Each, $\$ 1.00$ PEACH

Very large; skin brownish red, slightly coarse grained, but juicy; freestone; very popular. July.

\section{WASHINGTON}

A large plum; skin dull yellow, with a pale crimson blush; flesh firm; very sweet and luscious; freestone. Early August.

\section{YELLOW EGG}

Very large; skin of a deep golden color, but rather a cid; excellent for cooking; very showy. August.

Small round; flesh pale green, melting and juicy; freestone. Mid-July.

\section{BURBANK}

Medium; globular; cherry red, with lilac bloom; flesh yellow; bears very young. Late June. 


\section{GRAPES}

Prices except where noted: 2-yєar Plants...............Fach, \$0.15; per 10, $\$ 1.50$; per $100, \$ 8.00$; per $1000, \$ 70.00$ If wanted in large numbers, write for prices CONCORD

Large, black grape; bunches compact; berries round, sweet and pleasant. August.

\section{DELAWARE}

One of the finest of our native grapes; grows freely and is perfectly hardy; ripens early; berries small, light red. August.

\section{MCKINLEY (New)}

A new carly white grape of great merit; a strong, vigorous grower; thick, healthy foliage, and perfect self-fertilizing blossoms; bunches large and compact; fruit large, near. ly round; very sweet, with no acid around the seeds, and no puckery taste in the skin; skin thin, green at first, then turning to yellow: bears handling and shipping well. August.

Prices, 2-year, each, 25c; 10, $\$ 2.25$ NIAGARA

Bunch medium; berry large, roundish, uniform; skin thin but tough; pale yellow; flesh tender and sweet; vine vigorous and productive; one of the best white grapes. September.

\section{CAMPBELL'S EARLY}

Berries large, nearly round, black, with light purple bloom; flesh rather firm but tender; quality rich, sweet, slightly vinous; a strong and vigorous grower. August.

Price: 1 year, each, $25 \mathrm{c} ; 10, \$ 2.25$.

Price: 2 years, each, 35c; $10, \$ 3.25$.

\section{MOORE'S DIAMOND}

Bunches large; berry greenish white, flesh juicy and almost without pulp.

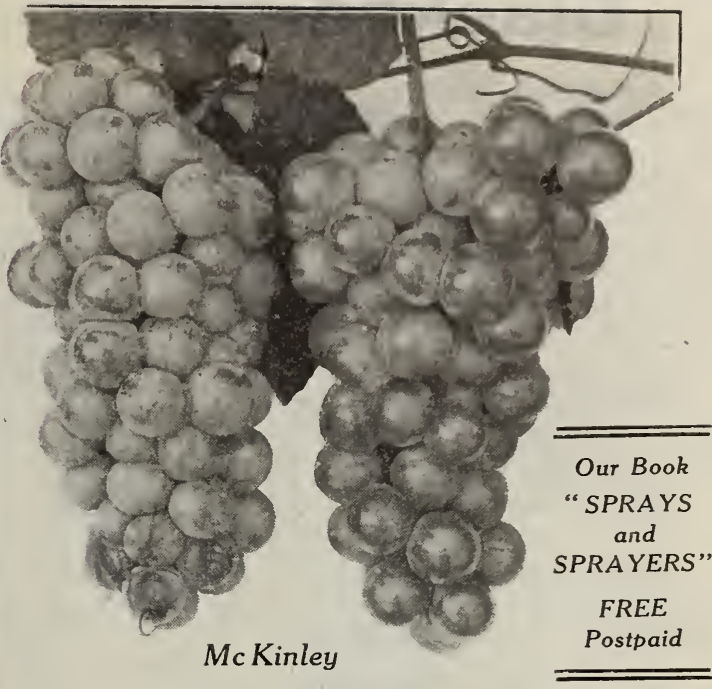

MCPIKE (New)

Bunches are large and compact; grapes of uniform extra large size of a blue black, covered with bloom. Ripens evenly and is of perfect quality; hardy everywhere. September. $\quad$ Price, 2-year, 25c; 10, $\$ 2.25$

\section{MOORE'S EARLY}

Bunch medium; berry large, resembling Concord, but more pulp and is earlier.

\section{POCKIINGTON}

Vine very vigorous, hardy and productive; bunch and berry of good size; color a light lemon yellow; flesh moderately tender, sweet. September.

Price, 2-year, each, 25c; per 10, \$2.25. WOF.DEN

Bunch very large and compact; berry large, black; an improved Concord. Late August.

\section{Thompson's Seedless, Tokay, Muscat, Malaga and other European Varieties, Choice Plants at above Prices}

\section{CURRANTS}

Currants are a profitable easily grown crop, and the market is always good. Prices except where noted............ Fach, \$0.10; Per 10, \$0.75; Per 100, \$6.00; Per $1000, \$ 50.00$

\section{New Varieties} PERFECTION

New; largest and most prolific Currant; bright red, rich flavor, mild sub-acid; no currant can approach in yield or quality this wonderful new currant.

Strong plants, each, 15c; $10, \$ 1.40 ; 100, \$ 12.50$ POMONA

A splendid new red variety; good keeper; has the record for acreage yield. About the size of Perfection and comes a little later.

Strong plants, each, 25c; $10, \$ 2.25 ; 100, \$ 15.00$ BFI工F DF BOSKOOP

A splendid new black currant excelling in quality and productiveness. A hardy, vigorous, grower; the largest and best black currant. Strong plants, each, $75 \mathrm{c}$.

\section{White Currants}

\section{WHIT TRANSPARENT}

The best white currant known. To be classed with the Perfection red. Splendid for market and table use; berries large, having a rich flavor; mild sub-acid. Vigorous and very productive.
L.drge, yellowish white, valuable for the table.

\section{BIACK NAPLES}

Very large, black, rich, tender and fine for jellies and wine. Productive and vigorous.

\section{Standard Varieties} CHERRY

Very large; deep red; fine for preserving; valuable market variety.

\section{FAY'S PROIIFIC}

Bright red, very sweet, stems longer than Cherry and fruit hangs on better than most varieties. To be planted with Cherry.

\section{NORTH STAR}

Strongest grower among red varieties; bunches average four inches in length; extra quality; very productive.

\section{VICTORIA}

Large, bright red bunches, very long; an erect grower; late, productive and very valuable. 


\section{Blackberries}

NEW MAMMOTH

This wonderful new blackberry is a rampant grower, of trailing habit; the foliage is large, thick, of a deep green color. It is enormously productive and exceedingly early, ripening three weeks before other cultivated kinds. Fruit is enormous, specimens measuring $21 / 2$ inches long; seeds small, soft and abundant; cores small and soft. In size and flavor it surpasses all other varieties of black. berries. July 1.

Two-year-old, each, 25c; 10, postpaid, $\$ 2.00$ Ten, by express or freight, $\$ 1.75 ; 100, \$ 15.00$ One year old (tips), ea., 15c; 10, postpaid, $\$ 1.25$

By express or freight, $10, \$ 1.00 ; 100, \$ 8.00$ KITTATINNY

Large, roundish, conical, glossy black, juicy, sweet, excellent when fully ripe. July. Each, 8c; 10, 60c; 100, $\$ 5.00$.

\section{BIOWFRS}

A new variety, said to be the best; very productive and a good shipper; exceedingly sweet. Ripens just after the Erie.July. Price, each, 15c; 10, \$1.25; $100, \$ 10.00$; postpaid, each, $20 \mathrm{c}$; per $10, \$ 1.75$.

\section{FRIF}

Large, coal black, round; standard variety. Vigorous. July. Each, 8c; 10, 60c; $100, \$ 5.00$.

\section{EVERGREEN}

An Oregon introduction; beautiful lacinated foliage, which it retains all winter; berries long, black, sweet, rich and delicious; ripens from July to November. 10 for $\$ 1.25 ; 100$ for $\$ 10.00$ Postpaid, each, 20c; 10, $\$ 1.50$

\section{HIMALAYA GIANT}

An exceedingly strong, rampant grower of a trailing nature; everbearing; an enormous yielder. The berries are large, juicy, coreless, sweet and firm, with a delicious aromatic flavor. Its deep rooting qualities enable it to produce a large, firm berry even in a very dry season. $\quad$ Postpaid, each, 20c; doz., $\$ 2.00$

Freight or Express, each, 15c; doz., $\$ 1.50$

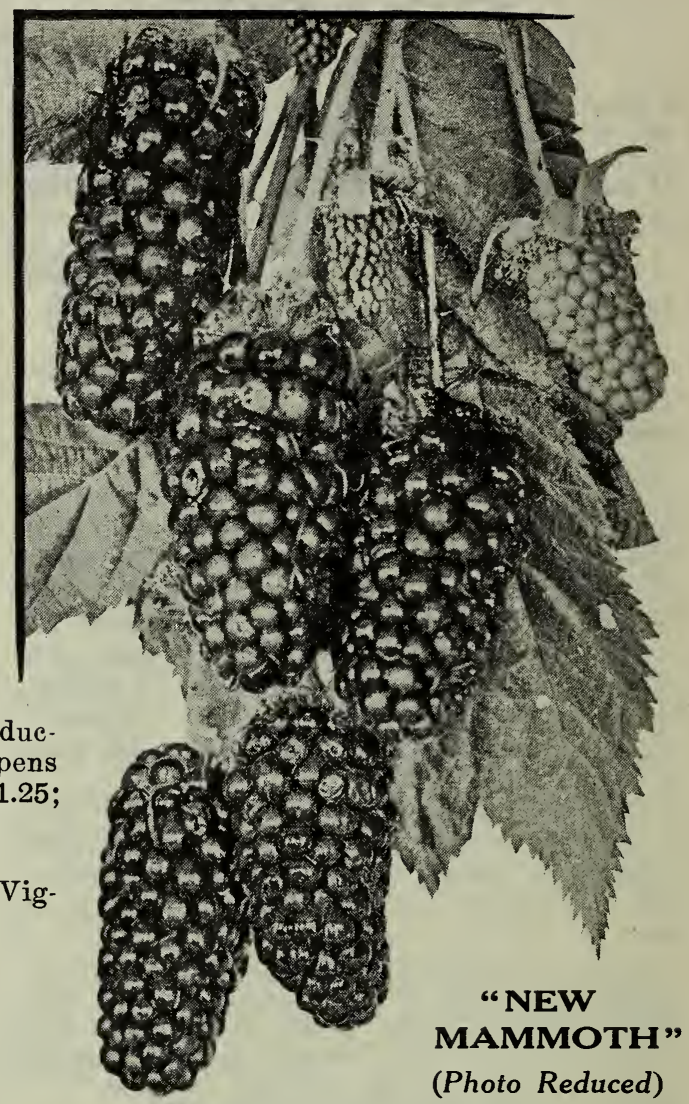

LAWTON

Fruit large; very productive; well and̄ favorably known; Oregon's most popular kind. Each, 8c; 10, 60c; 100, \$5.00.

\section{ELDORADO}

A valuable new variety; fruit large, jet black, melting, sweet and rich; hardy and very productive; fine for Oregon.

Each, 10c; 10, 90c; 100, $\$ 8.00$

Postpaid, each, $15 \mathrm{c} ; 10, \$ 1.25$

\section{Burbank's Phenomenal}

"Larger than the largest berry ever before known.", Bright crimson raspberry color, productive as could be desired, and most delicious of all berries for pies, canning jellies or jams. Sweeter than the Loganberry. Easily grown, stands shipping well, and hardy everywhere.

Compared with the Logan the color and general form are much the same the first season, particularly if the growing conditions have not been favorable, but when once established they have no equal in size, quality or productiveness. July 1.

Price, Each, 25c; per 10, $\$ 2.00$; per 100, $\$ 12.50$.

\section{Logan Berry}

The fruit is generally larger than the blackberry, often an inch and a quarter long; color dark red and produced in immense clusters. It partakes of the flavor of both the blackberry and raspberry, a mild, pleasant, vinous flavor, delicious and peculiar to this berry alone. Fruit ripens early, the bulk being gone before the blackberries or raspberries become plentiful. It is excellent for the table, eaten raw or stewed and is excellent for jelly or jam. June.

Price, each, 15c; per 10, $\$ 1.25$; per $100, \$ 8.00$.

\section{Dewberry}

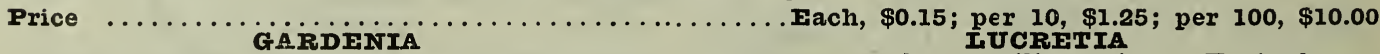

Very popular, trailing vine. Fruit large,

Large glossy black; delicious; heavy bear er; trailing vine. June. soft, sweet and with no hard core. Hardy, good for this Coast. Last of May. 


\section{Raspberries-Red Caps}

Prices except where noted

Per 10, \$0.75; Per 100, \$4.00; Per 1000, $\$ 20.00$

\section{THE IMPROVED SUPERLATIVE}

A New Berry of Great Merit

The color is a soft red crimson. The berry large and firm, with very small, brittle seeds. The healthy, vigorous growth, remarkable productiveness, hardiness, immense size, handsome, uniform shape and rich, luscious flavor make the "Superlative," from the shippers' standpoint, a most desirable berry. It is firm, disease resisting, and earlier than Cuthbert. Each, 20c; 10, \$1.65, postpaid HERE ERT

Three in one; splendid, large, bright red; strong grower and very productive; originated in Canada; should be tried by every planter. Price, strong rlintz, each, 25c; 10, \$2.00.

\section{CUTHEERT}

Deep rich red, large and firm; one of the best market berries. Very strong, hardy and productive; ripens medium to late.

\section{MARIBORO}

Standard, light crimson, large, very firm; should be planted with Cuthbert as commer. cial variety; ripens early.

\section{RED ANTWERP}

Eearlier and about the size of the Cuthbert; rich flavor; bright red, and a good market or home berry for this climate.

\section{GOIDEN QUEEN}

Yellow, large, fine quality; hardy and productive; should be in every home garden.

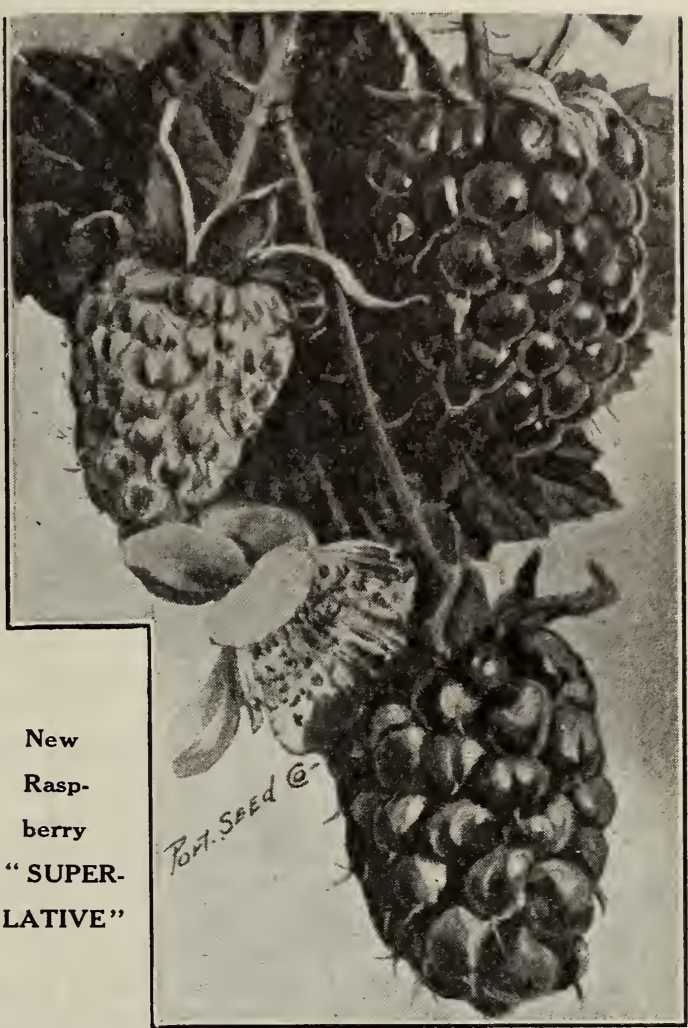

\section{GIANT RHUBARB A ${ }_{\text {PROFITABLE CROP }}^{\text {SUICK and }}$ EASY TO GROW-See page 57}

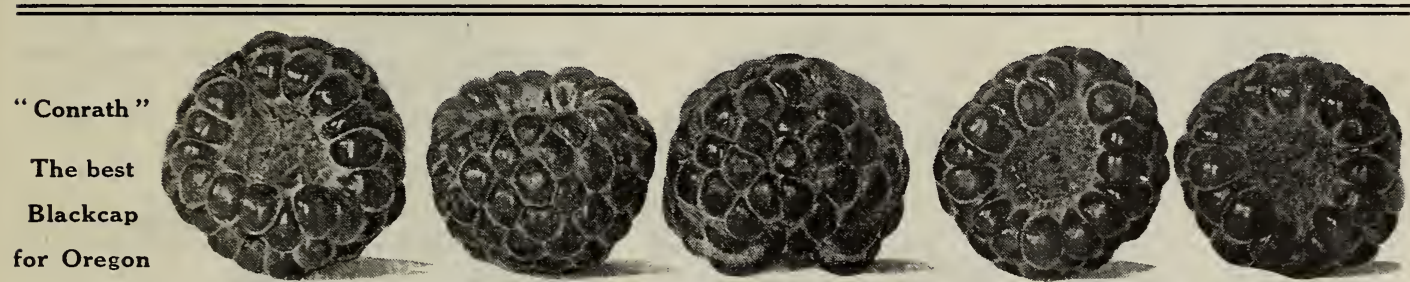

\section{RASPBERRIES - Black Caps}

Prices except where noted:

Choice well rooted plants, each, 10c; per 10, 90c; per 100, \$6.00; per 1000, $\$ 40.00$. CONRATH

The Best Early Blackcap

A black raspberry of superior quality, being ten days earlier than Gregg, coming in with the earliest reds. One-sixth of an acre of Conraths produced 38 24-pound crates, netting the grower $\$ 76$. We especially recommend the Conrath as the best "blackcap", for Oregon. Try it.

Choice, wellrooted plants, each, $15 \mathrm{c} ; 10, \$ 1.25$, postpaid Freight or express, $10, \$ 1.00 ; 100, \$ 8.00$

\section{COIUMBIAN}

Purple-black, large and quite firm. Fine market and canning fruit. Bush hardy and productive.

\section{KANSAS}

Black. Similar to Gregg, ripening earlier. Good commercially; strong grower and productive. Drouth resistant.

\section{CUMBERIANI}

Black; very large; similar to Gregg if not better.

Black, good quality. Not yet thoroughly tested.

MUNGER

Black, very good, juicy and fine for home use.

\section{GREGG}

Of good size, fine quality; very productive and hardy. It takes the same position among black caps as Cuthbert among the red sorts.

\section{PIUM FARMER}

New; very promising as a table and market berry; large black, hardy and productive. Good quality. Strong plants, postpaid, each, $15 \mathrm{c} ; 10, \$ 1.25$. Express or freight, 10, $\$ 1.00$; $100, \$ 8.00$. 


\section{STRAWBERRY PLANTS}

\section{"DIAMOND QUALITY"}

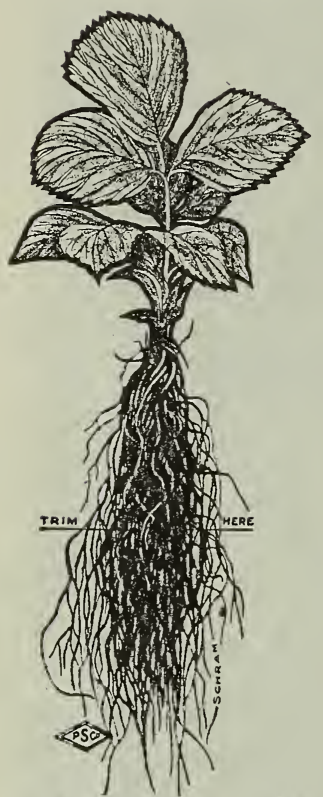

In setting, trim roots as indicated by line in illustration.

A TRAWBERRY PLANTS are a great specialty with us, and our select strains of New Oregon, Gold Dollar, New Acme, Magoon, Clark's Seedling and other Western varieties, many of which were introduced by ourselves, still hold their position as the leading commercial varieties of the Northwest, and are being planted more extensively each season. Thus demonstrating by actual market and growing tests the great superiority of our Western varieties, against the keenest competition from all sections.

Better Strawberries or larger crops are not produced anywhere than right here in the Northwest.

\section{Make No Mistake - Western Varieties ARE Best for WESTERN GROWERS}

"Diamond Quality", Strawberry Plants are large, vigorous and healthy. They are heavily rooted and have large, full crowns; have been carefully grown, and are free from disease and pests. We dig as ordered and pack for shipment in ventilated crates of 500 plants each, crowns up. They are grown from our select strains and are always true to name; no substitution is ever allowed without the full knowledge of the purchaser.

CARE FOR AND FEED YOUR PLANTS.

Neglect is the prime factor in strawberry failures, and most strawberry beds suffer from lack of attention and starvation. Proper fertilization and intelligent culture insure enormous crops of finest fruit and freedom from diseases and pests. White grubs, cutworms, crown miners, etc., can all be controlled by preventive measures. Never set strawberries on or near clover sod or hay fields. such ground should have at least two years cultivation before using for strawberries. Remove the mulch directly after fruiting. This helps to control many evils. For helpful details of care and culture, see our Strawberry Booklet, 32 pages, sent free on request.
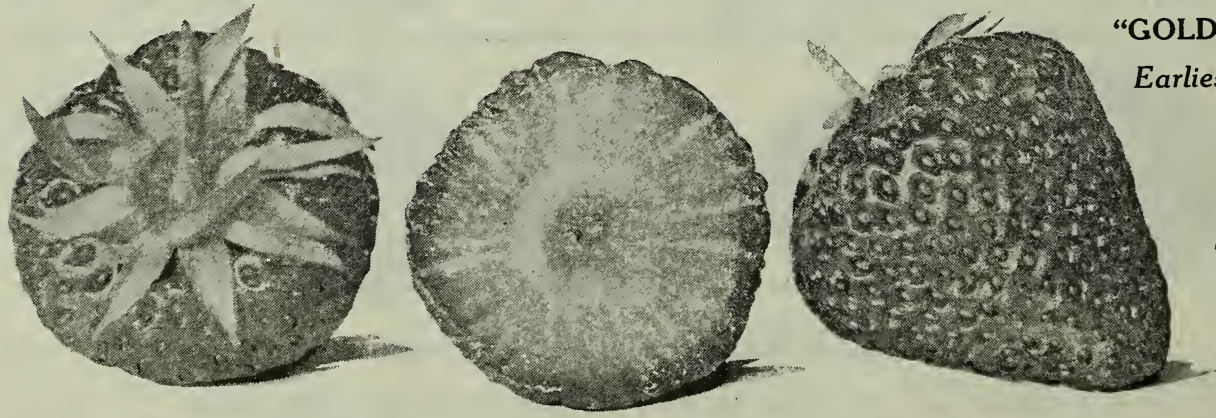

Earliest and Best

\section{Gold Dollar-Extra Early}

No early strawberry has ever been grown that equals our special strain of "Gold Dollars."

Gold Dollar berries are large size, dark red all through and have a fine flavor. Foliage heavy, large and spreading, which protects the blooms from early frosts. Has a perfect bloom, and strong stems that hold the berries up from the ground, which helps to keep color and flavor during the early rainy season.

Gold Dollar Strawberries are the standard early berry in the big markets of the Northwest and are always in demand. They are sure, heavy croppers, keep up their size throughout the season, and command the highest early prices. They are the handsomest, most profitable early strawberry.

Fin - The strawberries here offered have all stood the market test and you will be safe in selecting any one of them that will suit your conditions and requirements. They are the best varisties obtainable.

"Diamond" No. 4 - The Best Fertilizer for Strawberries. Our Sent FREE 


\title{
STRAWBERRY PLANTS - Continued
}
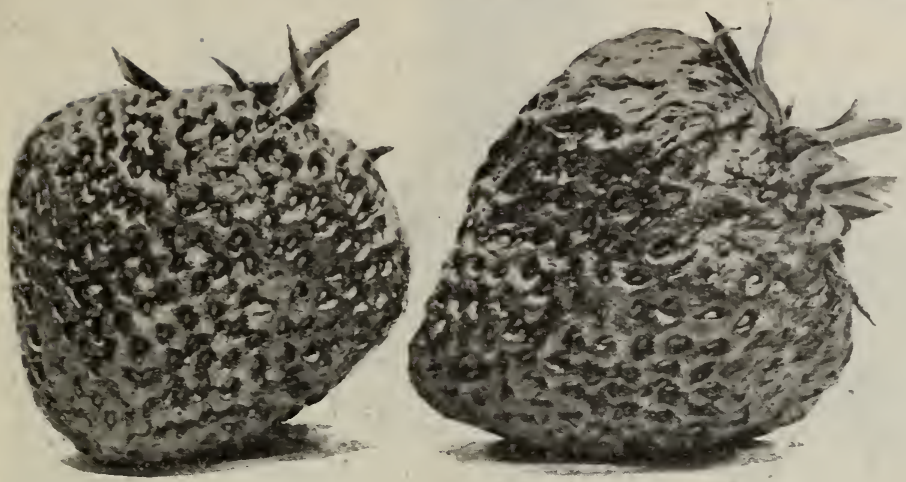

Our Own Introduction

\section{"NEW OREGON"}

\author{
Best, Most Uniform, \\ and Heaviest \\ Yielding Main Crop \\ Strawberry
}

"NEW OREGON" is large, firm and of fine form, averaging 15 to the quart box, color a brilliant, deep, rich red, having a glossy varnished appearance when fully ripe. This dark blood red coloring extends through to the very center, and, no matter how large, the "N⿴囗十 OREGON" is never hollow. When fully ripe "NEW OREGON" has a distinctive flaror suggestive of the wild berry, is crisp and delicious, and will remain on the vine for three days without injury, keeping perfectly for many days after picking; stands handling and long shipments and will hold its color, shape and flavor when canned.

"NFW OREGON" is an early and continuous bearer, being ready for marketing the first half of May in the Willamette Valley and holds up in size and quality throughout the season, which in some localities extends until frost.

"NEW OREGON" is a healthy, vigorous grower with luxuriant foliage, but has a marked characteristic of setting few runners. For this reason plants of the true strain cost a little more than other sorts. We introduced "NFW OREGON" in 1902 and groming tests with every promising variety obtainable have demonstrated its superiority.

Mr. Finnigan, the "Strawberry King," uses the "NFw OREGON" for his fancy pack, anr picked 16,872 boxes from two acres in one season.

TTo be sure of receiving the original strain of genuine "NFW OREGON" Strawberries send your orders directly to our Portland store.

\section{Popular and Best Western Sorts Marshall \\ New Acme}

One of the best all-round strawberries; very large; dark crimson throughout; fine flavor; a fine market and table berry.

\section{Clark's Seedling}

The berry that has made Hood River famous; best shipper; berries large, firm and of delicious flavor; vines bear large crops; is especially adapted to dry soil.

\section{Admiral Dewey}

Color, beautiful dark red, extending to the center; no white core; shape conical, much like Clark's Seedling; of excellent flavor; a very early, abundant and continuous bearer; might be classed as an ever. bearing.

\section{Wilson}

An old standard variety; a heavy bearer of fine, moderate sized berries; sharp acid flavor and the leading sort for canning.

For growers who have a distant market, or who require a firmer berry than any before known "Nep Acme" is specially recommended.

The Acme is a seedling of large size and same general form as the well known "Clark," but of much richer, more brilliant color. The seeds, being very prominent and of a rich, golden yellow, give the berry a strikingly handsome, distinctive appear. ance. It ripens early and is a heary cropper. berries remarkably uniform in size and shape; are also very firm, of finest quality, stand handling better and keep longer than any other strawberry.

\section{Magoon}

Originated near Portland; berry large, fine and excellent; sub-acid flavor; bears heavily throughout the season; especially adapted to Western Oregon and Washington.

\section{Gandy}

A profitsble market sort; its sesson is late to very late, being in its prime when most other sorts are gone. The fruit is large, handsome and uniform, and makes an excellent showing on the market.

$$
\text { By mail, postpaid. }
$$

Dozen 100

.$\$ 0.30$

.25

.25

.30

.30

.25

.25

.30

.25

By express or freight packed in venti-

$\begin{array}{cr}\text { lated crates. } & \\ 100 & 1000 \\ \$ 0.75 & \$ 6.00 \\ .60 & 4.50 \\ .60 & 4.50 \\ .75 & 5.00 \\ .75 & 5.00 \\ .60 & 4.50 \\ .60 & 4.50 \\ .75 & 6.00 \\ .60 & 4.50\end{array}$

Not less than 500 plants of a kind at 1000 rate. Special prices on 3000 or more. 


\section{GOOSEBERRIES}

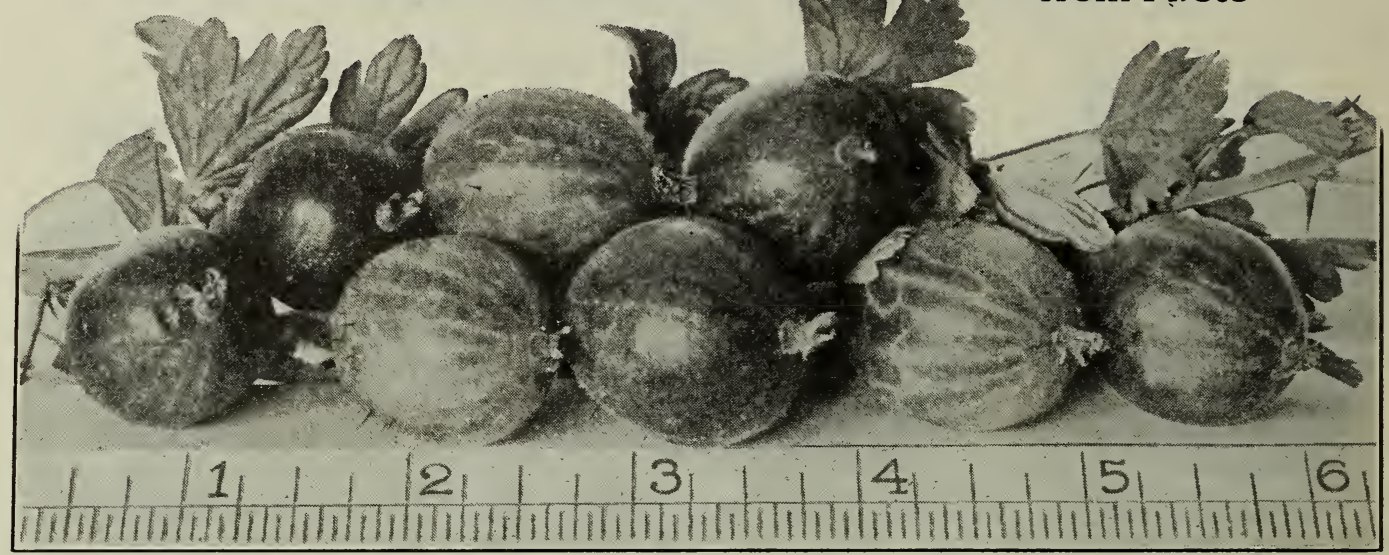

Prices except where noted.........Fach, \$0.10; Per 10, \$0.80; Per 100, \$5.00; Per $1000, \$ 45.00$ OREGON CHAMPION

Berries very large, pale green color; very sweet and fine for table use and pies; bush strong, not very thorny; very prolific bearer; most popular sort we have.

\section{HOUGHTON}

Vigorous grower, abundant bearer; fruit of medium size, pale red, sweet and juicy. RED JACKET (JOSSELYN)

Of large size; smooth, prolific and hardy; of best quality; a wonderful cropper, with bright, clean, healthy foliage.

Each, 15c; 10, \$1.25; 100, $\$ 12.00$

Large, light green; soft juicy and good. Vigorous and very productive.

\section{INDUSTRY}

Very large, dark red, of delicious flavor; the best of all English varieties. Bushes strong, upright and very productive.

Each, 20c; 10, \$1.75; 100, \$15.00

\section{PFARI}

Large, light yellowish green; very hardy and free from mildew; superior in size and quality. Very prolific.

\section{Vegetable Roots and Plants}

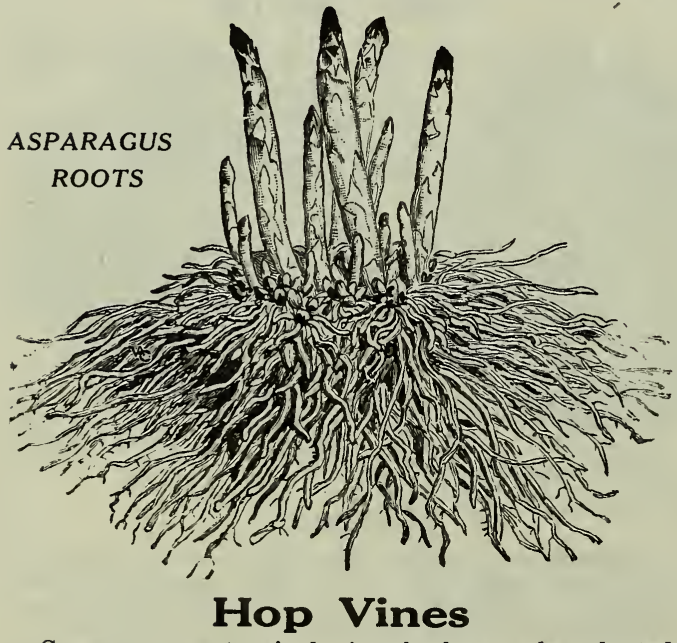

Grown very extensively. for the hops; also planted largely for shade and covering fences, buildings, etc.; rapid growers.

English Cluster-The best sort.

Strong roots, postpaid, 5c each; 40c per dozen. By express, 25c per dozen; $\$ 1.50$ per 100

Write for prices if wanted by the 1000 .

\section{Asparagus}

One of the earliest and finest of spring vegetables; very easily grown. A bed once planted is good for years if properly attended to and well manured.

CULTIVATION - See that the ground is well drained, work it up fine and deep and make it very rich with fertilizer or barnyard manure. Place the plants eight inches apart in rows three feet apart. Spread out the roots in a trench made deep enough to permit their crowns to be covered with three or four inches of mellow earth. Give the bed liberal dressings of fertilizer at intervals, and, except near the sets, three pounds of salt per square yard early every spring. Do not cut for use until the plants have grown two seasons.

We can supply Connover's Colossal, Palmetto and Columbian Mammoth White.

ONE-YEAR-OLD PLANTS-Postpaid, 25c dozen; 75 c per $50 ; \$ 1.00$ per 100 . By express or freight, 20c dozen; 50c per 50; 75c per 100; $\$ 6.00$ per 1000 .

TWO-YEAR-OLD PLANTS-Postpaid, 40c dozen; $\$ 1.00$ per $50 ; \$ 1.50$ per 100 . By express or freight, 25c dozen; 75 c per $50 ; \$ 1.00$ per $100 ; \$ 8.00$ per 1000

\section{Horse Radish}

This useful condiment is easily grown and prefers a rich, moist loam. Plant in rows eighteen inches apart, putting the sets one foot apart, being careful to place the thin end down in the ground. Constant cultivation required: $40 \mathrm{c}$ per dozen. By express or freight, 25c per dozen; $\$ 1.50$ per 100 . Write for prices by the 1000 .

\section{High Grade Fertilizers Cheapest}

A 100-pound bag of high grade commercial fertilizer will contain more soluble and available plant food than 4,000 pounds (two tons) of stable manure of average quality. Fow much easier and cleaner to handle one 100-pound bag than tons of manure, and there are no weed seeds to worry over.

Special Fertilizer Booklet giving complete analysis and price of the different fertilizers which we can supply, together with full information for their application, will be sent on request. This book is of great value to all interested in fertilizers. 


\section{VEGETABLE PLANTS-Continued Rhubarb, or Pie Plant}

This deserves to be ranked among the best early products of the garden. It affords the earliest material for fine pies and fresh table sauce, continues long in use and is valuable for canning.

A deep rich soil is indispensable to secure large, heavy stalks. Plant in rows four feet apart, with the plants three feet distant. Set so that the crowns are about an inch below the surface. Apply annually, in the fall, top dressing of stable manure, and fork under in the spring.

\section{GIANT-BEST HARDY VARIETY}

ONE-YEAR-OLD ROOTS-Postpaid, 8c each; $75 \mathrm{c}$ per dozen By express or freight, 50c per dozen; $\$ 3.00$ per 100.

TWO-YEAR-OLD ROOTS-Postpaid, 15c each: $\$ 1.50$ per dozen. By express or freight, $85 \mathrm{c}$ per dozen; $\$ 6.00$ per 100.

\section{VEGETABLES PLANTS}

We grow large quantities of vegetable plants, and can supply all the kinds listed below, in their proper season, in most any quantity. We have made arrangements this year so that we can supply all vegetable plants in two grades. If you want a quantity of plants write us early.

Transplanted plants are much stronger and better rooted, and are well worth the price, especially in the early part of the season. We can supply most any of the leading sorts. No plants sent C. O. D.

Write for prices in large quantities.

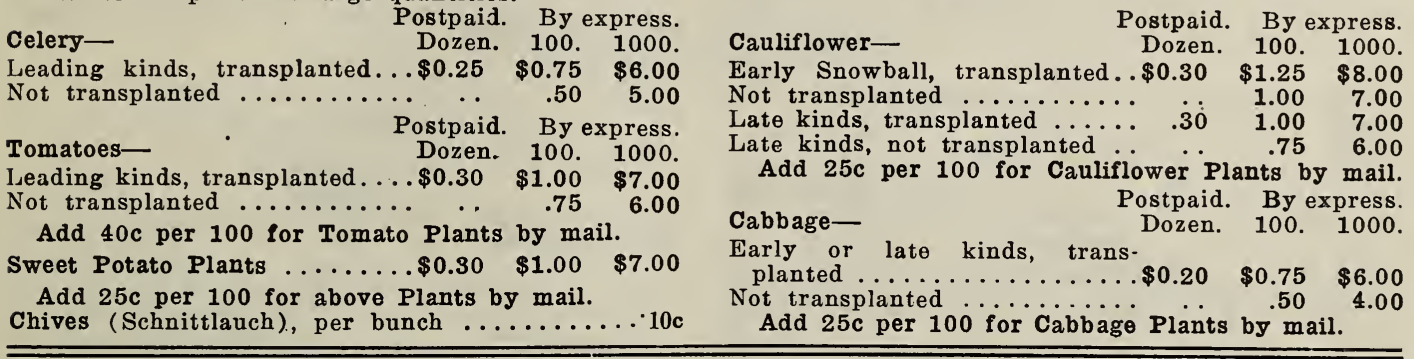

Spraying to be effective must be well done. We recommend the GOUID SPRAY PUMPS as the most efficient and satisfactory sprayers. Complete outfits, all styles, for every requirement, can be furnished on demand. Full information on request.

\section{Spray Calendar-When to Spray, What to use}

\begin{tabular}{|c|c|c|c|}
\hline Insect or Disease. & Plant Attacked. & What to Spray With. & First Spraying. \\
\hline 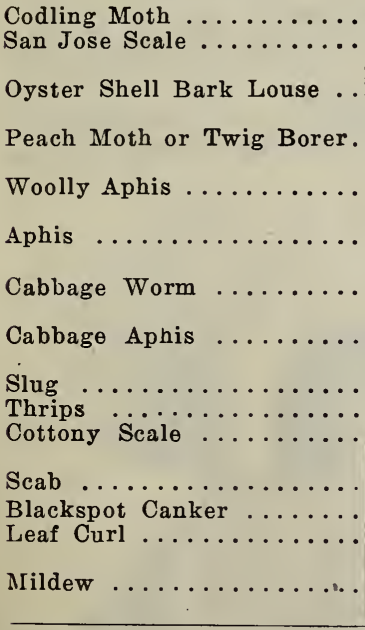 & 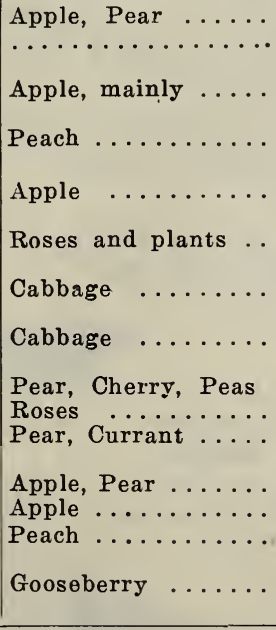 & 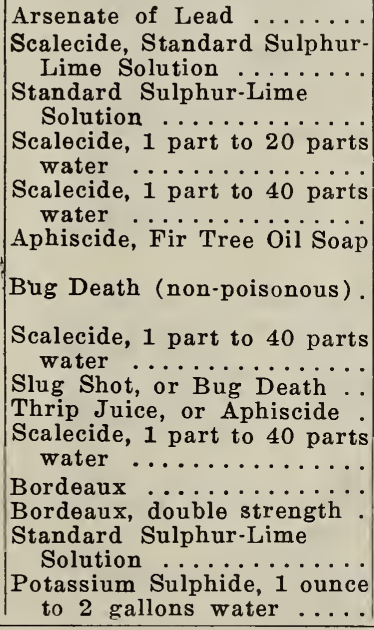 & $\begin{array}{l}\text { Just before calyx cups close. } \\
\text { When leaves are off the tree. } \\
\text { When leaves are off the tree. } \\
\text { When the insects appear. } \\
\text { When the insects appear. } \\
\text { Just as soon as the insects } \\
\text { appear. } \\
\text { Before the worms eat into } \\
\text { the cabbage. } \\
\text { When the insects appear. } \\
\text { When the insects appear. } \\
\text { When insects become cot- } \\
\text { tony (May). } \\
\text { Just before blossoms open. } \\
\text { Immediately after leaves fall. } \\
\text { Before buds burst. } \\
\text { Just as buds burst. }\end{array}$ \\
\hline
\end{tabular}

Q A A barrel of "Scalecide" will spray more trees than 31/3 bbls. Lime and Sulphur, at less expense, with less work, and better results. "SCALECIDE" will not injure your pump or outfit will not harm your skin or eyes.

6 Years of Systematic Spraying with "Scalecide" has resulted in record yields in some of the largest apple and peach orchards of the United States. Interesting literature and sample of "Scalecide" will be sent Free on Request.

SPREADS AND PENETRATES - KILLS ALL SCALE AND FUNGUNS. 
$\mathbf{S}$

PACE will not permit us to more than give the very briefest description of ornamentals in this booklet, but complete descriptions and detailed information covering your plant-

ing problems will be promptly and cheerfully furnished on request, together with such suggestions as we feel will prove helpful to you. We shall be pleased to quote special prices on larger grades than those offered in the list. Such varieties as we have marked with an asterisk $\left(^{*}\right)$ can be supplied in many cases in larger grades and in large quantities.

When large trees are planted, they shou ? be cut down to within 8 feet of the ground and all laterals should be shortened in, thinned out if they are too thick and cut away entirely to about 6 feet of the ground.

We shall be pleased to give quotations to persons desiring large quantities.

Prices of the following are for the 7 to 8 feet grade, excepting where otherwise specified.

\section{Deciduous Trees}

\section{ASH}

American White

Broad, round head and dense foliage. Very fine. Each, 60c; $10, \$ 5.00$.

(See Linden).

\section{BASSWOOD}

Purple Leaved-Foliage is deep purple in the spring, changing to crimson in the fall. 5 to 6 feet, each $\$ 2.00 ; 6$ to 8 feet, $\$ 3.00$

\section{American} $\$ 6.00$

Unequalled for splendor. Each, 75c; 10,

\section{Fern Ieaved}

European variety, shrub-like and very beautiful for the lawn. 4-5 feet, each, \$1:00; per 10, $\$ 7.50$.

\section{*BIRCE}

European White

Silvery white bark and slender drooping branches. Each, 75c; 10, \$6.50.

Cut Leaved

Delicately cut foliage, silvery white bark and drooping branches. Bach, $\$ 1.25 ; 10, \$ 11.00$. CATAIPA

Splendid trees with white flowers and bright green foliage.

\section{CATALPA BUNGTI}

Forms a dense, round, umbrella-like head. Each, $\$ 1.50$.

*CATAIPA WFSTFRN (Speciosa)

Very rapid grower, fine as a quicl shade. Price, 7 to 8 feet, each, $75 \mathrm{c}$.

CRAB-Flowering (Bechtels)

Flowers pink and very fragrant. In appearance a tree of roses. 5 to 6 feet, each, 75c. CORINUS FIORIDA (Dogwood, White Flow-

Flowers white, 3 inches in diameter, blooming before leaves come in spring. Grows 20 to 25 feet high and is very showy. Price, 7 to 8 feet, each, 60c; $10, \$ 5.00$.

\section{* FIM}

\section{American White}

A native of this section: a magnificent tree with drooning branches. Each, 75c; 10, \$6.50.

$$
\text { *IABURNUM (Golden Chain) }
$$

A beautiful small growing tree with long. drooping racemes of fragrant yellow flowers. 5 to 6 feet, each, $75 \mathrm{c}$.

\section{IARCH}

Tree native, rapid growing. Each, 75c; 10,

*Cork Bark

street planting. Young

\section{Purple Ieaved}

Leaves rich purple when young. Each, 75c; $10, \$ 6.50$.

\section{FRINGE TREF}

Small; foliage dark green; bunches of pure white flowers in May. 4 to 6 feet, $\$ 1.00$.

\section{HAWTHORNT}

Double Scarlet

Small tree with spreading branches and crinison flowers. Each, 75c; per 10, \$6.50. Double white

Flowers small, leaves lustrous green color. $75 \mathrm{c} ; 10, \$ 6.50$.

\section{HORSE CHESTNUT}

\section{*White}

Foliage showy, flowers stand in upright panicles. Each, $\$ 1.10 ; 10, \$ 8.00$.

$$
\text { * Red }
$$

Same as above; flowers red. Fach, \$1.10; $10, \$ 8.00$.

\section{IINDEN}

American

Shapely and handsome, foliage large. Fach, $\$ 1.00 ; 10, \$ 8.50$.

Furopean $\$ 1.25$.

See Tulip tree.

\section{IIRIODENQDRON}

\section{IOCUST}

\section{HoCUst}

Rapid grower; fine for street planting. Each, $75 \mathrm{c} ; 10, \$ 6.50$.

Rapid grower, a drougth resister: fine for hedge or wind-break. Each, 75c: 10, $\$ 6.50$.

IMAGNOIIA-Acuminata, Cucumber Tree

Tall, pyramidal tree, showy leaves and yellowish white flowers. Each, $\$ 1.50 ; 10, \$ 12.50$.

\section{TAPT.T}

\section{Ash-Ieaved (Box Flder)}

A rapid grower, fine street tree, foliage ash-like. Fach, $\$ 1.00 ; 10, \$ 8.50$.

*Oregon Soft

A rapid grower, fine for avenues. Leaves large. 6 to 8 feet, $50 \mathrm{c}$ to $60 \mathrm{c}: 8$ to $10 \mathrm{fect}, 75 \mathrm{c}$ to $\$ 1.00$.

Tree large and *Sycamore with handsome foliage. 6 to 8 feet, $50 \mathrm{c}$ to $60 \mathrm{c}: 8$ to 10 feet, $75 \mathrm{c}$ to $\$ 1.00$.

\section{Silver}

A rapid grower, graceful and very beautiful; leaves silvery. 6 to 8 feet, $50 \mathrm{c}$ to $60 \mathrm{c} ; 8$ to 10 feet, $75 \mathrm{c}$ to $\$ 1.00$.

\section{Betchtel's Double Flowering Crab}

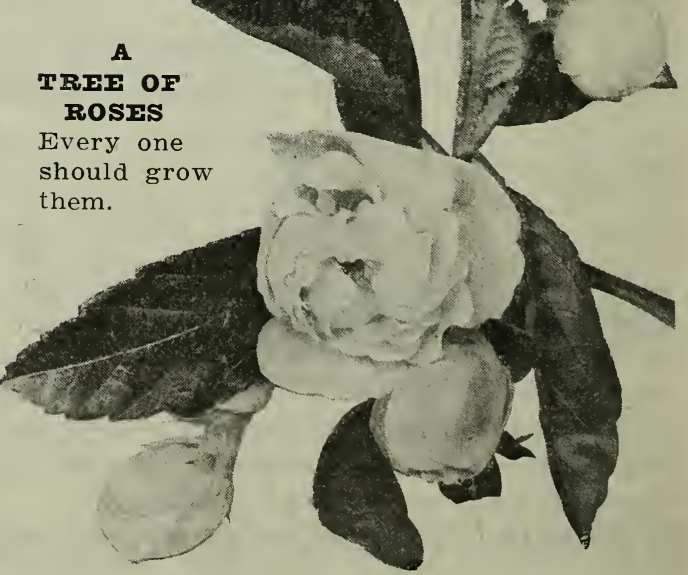




\section{DECIDUOUS TREES - Continued}

\section{* Norway}

Large, growth compact; foliage deep green Handsome. 6 to 8 feet, $50 \mathrm{c}$ to $60 \mathrm{c}$; 8 to 10 feet, $75 \mathrm{c}$ to $\$ 1.00$

Parple Ieaf Sycamore

Purplish green foliage, sycamore-like. 6 to 8 feet, $50 \mathrm{c}$ to $60 \mathrm{c} ; 8$ to 10 feet, $75 \mathrm{c}$ to $\$ 1.00$.

\section{Sugar or $\mathbf{n a r d}$}

A rapid grower; popular in the East, a shapely tree with beautiful autumnal coloring. 6 to 8 feet, $50 \mathrm{c}$ to $60 \mathrm{c} ; 8$ to $10 \mathrm{fe} t, 75 \mathrm{c}$ to $\$ 1.00$.

\section{*MOUNTAIT ASF}

Very ornamental, handsome foliage turning orange red in the fall. Red berries remain on tree most of winter. 75c; 10, \$6.50.

\section{MOUNTAIN ASF-Furopean}

White flowers, then beautiful red berries. Each, 75c; 10, \$6.50.

\section{MUIBFRRY}

\section{Downing's sverbearing}

A rapid grower with good fruit. Fine as a shade tree. $\mathbf{F a c h}, 75 \mathrm{c} ; 10, \$ 6.50$.

$$
\text { * Russian }
$$

Of spreading habit and rapid growth. Fach, $75 \mathrm{c} ; 10, \$ 6.50$.

See Nut Trees.

\section{WAINUT}

\section{OAK}

Low growing, spreading habit and rapid glowth. 75c; 10, $\$ 6.50$.

Scarlet

Pyramidal shape, foliage changes to bright red in fall. Each, 75c; 10, \$6.50.

\section{PFACE-Flowerin}

Blooms in April, flowers highly colored and very attractive. 4 to 6 feet, $50 \mathrm{c} ; 10, \$ 4.00$. POPLAR

* Carolina

A very rapid grower. Each, 60c; $10, \$ 5.00$ PRUNUS PISSARDT

Foliage and fruit entirely red. Plums very good quality. Very attractive. $\$ 1.00 ; 4$ to 6 feet, $75 c$.

\section{SYCAMORT}

Has broad foliage and handsome bark. 4 to

6 fe€t, $75 \mathrm{c}$; $10, \$ 6.50$.

Erect growing tree with mottled trunk. Foliage bright green. Fach, 75c; 10, \$5.50.

\section{TUIIP TREF}

Leaves light, glossy green, fiddle shaped flowers greenish yellow, tulip shaped. Fach $\$ 1.50 ; 4$ to 6 feet, $\$ 1.00$.

\section{Weeping Trees}

\section{ASH-Furopean Weeping}

Splendid arbor tree. $\$ 1.25 ; 10, \$ 11.00$

BABYIONICA or Common
Well known common willow, with drooping branchlets. 5 to 6 feet, each, $60 \mathrm{c}$.

CERRRY-Japanese White

Graceful and very beautiful, hard to equal. 4 to 6 feet, $\$ 1.25$.

rIM-Camperdown Weeping

Vigorous branches, forming a roof-like head. $\$ 1.50$; per 10, $\$ 12.50$.

MAPIE-Wier's Cut-Leaved

Very handsome with cut foliage. feet, $\$ 1.50$.

\section{MULBFRRY-Tea's Weeping}

Very graceful; branches long and slender and drooping parallel to trunk. Fach, $\$ 1.50$. per 10, \$12.50.

\section{WEPPITG WILIOW-Kilmarnock}

A distinct variety, having reddish shoots and large, glossy foliage. They make a most desirable and graceful drooping small tree for lawns. 6 feet and 2-year heads, each, $\$ 1.00$ to $\$ 1.50$.

WIIIOW-Wisconsin

Large, glossy leaves and very pendulous habit. Each, 75c; per $10, \$ 6.50$.

\section{NUT TREES}

\section{Almond (Nut Bearing)}

Almonds can be grown successfully in many sections of Oregon and Washington, and are attracting much attention from commercial orchardists We can supply most of the leading varieties at price listed Special prices on large orders.

Choice trees, 3 to 5 feet, each, $50 \mathrm{c}$

I. X. L.-A vigorous grower and sure cropper, producing nuts of large size and handsome appearance; shell thin; most popular commercial sort.

Hard Shell-A fine hardy variety with large plump kernel of good̉ quality.

\section{NONPARIEL}

Tree beautiful, slightly weeping; nut sweet and shell very thin. Best for the home.

\section{NE PLUS ULTRA}

Large and very long; soft shell; hulls free. Tree heavy and regular bearer.

\section{Butternut}

A beautifully formed tree bearing a rough coated nut of most attractive flavor, well known to the Middle West. Succeeds fairly well in the Pacific States.

Price, each, $50 \mathrm{c}$ to $75 \mathrm{c}$

\section{Chestnut}

American Sweet-Makes a handsome shade tree; full medium size, sweet and well flavored.

7 to 8 feet, each, $75 \mathrm{c}$ to $\$ 1.00$

Spanish-A valuable species, both for ornamental use and fruit. It forms a handsome lawn tree and produces much larger fruit than the American variety.

4 to 6 feet, each, $75 \mathrm{c} ; 7$ to 8 feet, $\$ 1.00$

Mammoth Japanese-A variety we import from Japan; yields much the best and largest fruit.

Each, $75 \mathrm{c}$ to $\$ 1.00$

\section{PARAGON}

Nuts large and handsome, sweet and of good quality. Tree hardy and very productive. 4 to 6 feet, each, $75 \mathrm{c}$ to $\$ 1.00$.

\section{Filberts}

Barcelona-Magnificent large nut from Spain, first quality; can be grown as low standard tree or bush. Each, 35c to 50c

DuChilly-The largest Filbert on Pacific Coast. Nuts are broad, 1 inch by $3 / 4$ of an inch; full fleshed and sweet; best grown as low standard. Each, 35c to $50 \mathrm{c}$

Special prices on large orders. 


\section{NUT TREES - Continued}

\section{Walnuts}

English or French-The cultivation of En. glish Walnuts on the Pacific Coast is very profitable, and many people are now setting out large groves. If you do not care to set out a field of trees, a row set along the driveway, lane, around the fences, or on a sidehill too steep to cultivate will prove a most profitable investment, and wiil require very little attention. They are rapid growers, and will make fair-sized trees in a few years. For those who prefer "second generation," we have a fine lot of one and twoyear-old trees (the best age to plant). These are nut-bearing, second-generation stock, and of the best varieties on the Coast, Franquette, Mayette, Praeparturien, etc.

\section{CAIIFORINIA BIACK}

A rapid grower and very desirable; nut medium size, with hard, smooth shell. Adapts itself easily to different climates.
FRANQUTTE AND MAYFTTE Second generation, soft shell, selected stock; very good, sweet and good tasting. Trees hardy and prolific bearers. Nuts are rich and meaty, finest commercial sorts.

\section{PRICES}

One-year-old, well-rooted, each, 25c; $10, \$ 2.00$ Two-year-old, well rooted, tops 2 feet up, 40c Seedling stock grown from select nuts, 4 to 6 feet, each, $75 \mathrm{c} ; 6$ to 8 feet, $75 \mathrm{c}$ to $\$ 1.00$

\section{FRANOUETTP}

Grafted on California Black

Quite large, elongated oval, and very attractive, kernel full, sweet and of a rich nutty flavor.

GRAFTED STOCK, 4 to 6 feet, $\$ 1.50$ to $\$ 2.00$

Special prices on large lots.

\section{Hickory}

\section{Shellbark}

Popular Eastern variety, tree hardy but slow grower. Nuts medium size, very good. Quality excellent.

Price, 3 to 4 feet, each, 75c

\section{Evergreen Trees}

7 HIS list includes trees that do not shed all their foliage at one time, thereby remaining green after the decidious trees are bare.

ARAUCARIA IMBRICATA-IMonkey Puzzle A fine tree of regular pyramiaal form: leaves bright green, broad, thick, pointed and overlapping each other. 2 to 3 feet, $\mathbf{\$ 2 . 0 0}$.

\section{ARBORVITAT}

*A merican

Native, known as white cedar. Foliage bright green, yellow-green underneath; brown and bronze in winter. 2 to 3 feet, $75 \mathrm{c}$

\section{Golden}

Elegant: habit regular: foliage tinged with gold in spring. 2 to 3 feet, $\$ 1.50$.

\section{weeping}

Weeping variety, branches pendulous and thread-like; foliage light yellowish green. 2 to 3 feet, $\$ 1.50$.

\section{American Variegated Pyramidal}

Pyramidal form, foliage dark green. 2 to 3 feet, $\$ 1.00$.

Fine, with close ascending branches of a fan shaped appearance. 2 to 3 feet, $\$ 1.00$.

\section{CIDAI}

Deodora (Fimalayan or Indian Cedar)

Very handsome; branches drooping; foliage silvery green. Very popular. Vigorous grower. 2 to 3 feet, $\$ 1.50$.

Deodora Variegata (Variegated Cedar)

A fine tree, same as Deodora with silvery white tipped foliage. 2 to 3 feet, $\$ 2.00$.

\section{CIPIJISS}

Graceful and conspicuous; branches horizontal, slightly pendulous, foliage dark green 2 to 3 feet, $\$ 1.25$; per 10, $\$ 10.00$.

$$
\text { Iawson Blue }
$$

Of slender habit with silvery foliage. $11 / 2$ to 2 feet, $\$ 1.00$.

\section{FIR}

Prized for its delightful aroma. $1: / 2$ to 2 feet, $\$ 1.25$.

\section{Turopean}

Splendid; branches spreading, foliage broad and silvery. 2 to $\mathbf{3}$ feet, $\mathbf{\$ 1 . 2 5}$.

Nordman's

Lustrous, deep green foliage; very symmetrical. One of the best. 1 to $11 / 2$ feet, $\$ 1.25$. White

A fine spruce; rapid growth; very hardy. Very attractive. $11 / 2$ to 2 feet, $\$ 1.50$
FPMIOCK-American

Very beautiful and appealing; branches pendant and foliage deep green. 2 to 3 feet, $75 \mathrm{c}$; per 10, $\$ 6.50$.

\section{Holly (Ilex)}

We have a fine lot of Hollies, both seedling and grafted stock. If wanted in quantity, write for special prices. We also have at different times very large fine specimens, with or without berries. Each, from $\$ 10.00$ up

English (Aquifolia) - A beautiful lawn tree, with prickly, dark green foliage; grows moderately fast, and is covered during the winter months with bright red berries. One of the handsomest and most popular evergreen bushes we know of. Holly branches are cut and sold in large quantities for holiday decorations. Berry-bearing plants, per foot, $\$ 1.00$; nice plants, $\$ 2.50$ to $\$ 6.00$; ordinary stock, per foot, $75 \mathrm{c}$; nice plants, $\$ 1.50$ to $\$ 3.00$

\section{Variegated Hollies}

The variegated varieties are remarkably handsome lawn plants. The leaves are variously marked with yellow or white. We offer the following distinct sorts:

Golden Margined - Leaves splashed with pale green; narrow, but irregular; golden edge.

Per foot, $\$ 1.00$ to $\$ 1.50$

Silver Margined-Leaves long, dark green, slightly mottled, and with an irregular, narrowish silvery margin.

Per foot, $\$ 1.00$ to $\$ 1.50$

\section{JUINIPEF}

$$
\text { Irish }
$$

Pyramidal in form, foliage silvery gray; very striking. 2 to 3 feet, $\$ 1.00$ Ied Cedar

Native, with striking form and beautiful color. 2 to 3 feet, $60 \mathrm{c}$; per $10, \$ 5.00$. 


\section{EVERGREEN TREES Continued}

\section{Swedish}

Similar to Irish, upright; one of the best. 2 to 3 feet, $\$ 1.00$.

\section{PIN}

Austrian

Well known and widely planted, especially at seashore: growth rapid; quite hardy. 2 to 3 feet, $\$ 1.00$.

\section{Scotch}

Robust growth: branches pendulous; leaves bluish green. 3 to 4 feet, $75 \mathrm{c}$; per 10, $\$ 6.50$. SPRUCA

A lofty, rapid grower; branches drooping. Fine for hedge or windbreak. 2 to 3 feet, $\$ 1.25$.

Norway Variegated Golden
Foliage golden yellow, vigorous. feet, \$2.00.
SPRUCE-Colorado Blue

The most beautiful of spruces; foliage silvery blue. $11 / 2$ to 2 feet, $\$ 2.50$.

\section{Douglas}

somewhat similar to our hemlock; rapid grower. 2 to 3 feet, $\$ 1.50$.

\section{YEW}

Finglish

Slow growth, densely branched, head spreading, dark green leaves. 2 to 3 feet, $\$ 1.00$.

Upright. deep, dark green foliage. 2 to 3 feet, $\$ 1.50$.

\section{Variegated}

Same as Irish, but with part of foliage striped and margined with silvery white. 2 to 3 feet, $\$ 1.50$.

\section{Evergreen Shrubs}

\section{PRIVET (Evergreen)}

One of our best heage plants; has small, pointed, evergreen leaves; grows rapidly and compactly; stands severe pruning, and can be kept in fine shape with little care.

1-year-old plants, 12 inches, each, $5 c ; 50, \$ 1.75 ; 100, \$ 3.00 ; 2$-year-old plants, $11 / 2$ to 2 feet, each, $10 \mathrm{c} ; 50, \$ 3.50 ; 100, \$ 6.00$

\section{Rhododendron}

Grafted Varieties-Magnificent, June and July flowering, evergreen shrubs; the finest and most hardy of all evergreens; they prefer a somewhat shady situation. There are many varieties, the flowers of which are produced in great abundance and in shades of the following colors: White, blue, purple, cherry, lilac, mauve and crimson.

Choice plants, $1 \frac{1 / 2}{2}$ to 2 feet and according to number of buds, $\$ 1.50$ to $\$ 3.00$

Ponticum-Flowers purple, often spotted on the upper lobe, and freely produced in short terminal corymbs.

\section{BROOM - Scotch}

bright bright yellow pea-shaped flowers. 3 to 4 feet, 50c.

White Flowering

75c. superior as Scotch; upright; branches leafless, throughout the summer; larger, nicer flower; very desirable. 3 to 4 fiet: 'itc.

\section{FUONYMUS - Jap.}

Dense, upright; leaves dark green (hedse) 2 to 3 feet, $50 c$.

Gold (and silver). 3 to 4 feet, $\$ 1.00$.

\section{IAURISTINUS}

Many white flowers in winter; fine hedge. Price, 2 to 3 feet, $75 \mathrm{c}$ each.

\section{IAUREI}

Portugal

Dwarfish, leaves dark green, flowers very sweet. 2 to 3 feet, \$1.25; per 10, \$10.00.

$$
\text { English }
$$

Leaves broad, shining; flowers in clusters, creamy white. Purple berries. 2 to 3 feet, $\$ 1.00$.

MARONIA-Aquifolia (Oregon Grape)

Shining, purple, prickly leaves; bright flowers, yellow: berries blue-black. 2 to 3 feet, 75c (Balled).

\section{Deciduous Shrubs}

\section{AITHEA-Rose of Sharon}

Flowers delicate, bell shaped, blooming at different times during summer. 3 to 4 feet, Grandiflora Superba

Double, delicate blush, carmine center. 3 to 4 feet, each, $50 \mathrm{c}$; $10, \$ 4.00$.

$$
\text { Flegantissima }
$$

Double white. 3 to 4 feet, each, 50c; 10 , $\$ 4.00$.

\section{Meehani}

Leaves variegated, single lilac-pink flowers. $60 \mathrm{c}$.

\section{FIOWFRING AIMOND-White}

Same, though white flowers.

\section{FLOWFRING ALMOND-Pink}

Well known early dwarf shrub Double clear pink little roses festoon the gracefully bending branches. 2 feet, $50 \mathrm{c}$.

\section{AZAIrA MOIIIS}

Very bushy, a young and proficient bloomer. Colors, red, orange and yellow. \$1.00.

$$
\text { BARBERRY-Purple Ieaved }
$$

Having purple foliage, very pretty. Clamp, $25 \mathrm{ceach}$.

\section{CURRANT-Flowering}

Graceful ;flowers and berries red. Very desirable for shady spots. 3 to 4 feet, 50 c.

$$
\text { IOFPYSUCKIF-Upright }
$$

Very beautiful. 3 to 4 feet, 50c. For others, see vines.

\section{DOGWOOD}

\section{Cornus Florida.}

White flowering dogwood. See decidious trees.

\section{DEUTZIA-Pride of Rochester}

Tall, very beautiful. Flowers double white. 3 to 4 feet, 50c; 4 to 6 feet, $65 \mathrm{c} ; 6$ to 8 feet, $75 \mathrm{c}$.

\section{TIPR-Cut Teared}

Deep, cut foliage. 4 to 6 feet, 50c.

$$
\text { FUONYMUS-Furopean }
$$

Strawberry or Spindle Trer-A small tree bearing medium sized scarlet berries. 4 to 5 feet, 50c.

\section{FIIBFRT-Purple Ieaved}

Leaves and husks purple, very ornamental Nuts good. 3 to 4 feet, $75 \mathrm{c}$.

\section{FORSYTHIA (Golden Bell)}

Most common; deep green foliage. Fine in partial shade. 5 to 6 feet, $50 \mathrm{c}$.

\section{CAIYCANTHUS-Floridus}

Flowers reddish brown, sweet scented. Leaves broad, dark green, making graceful masses. 2 to 3 feet, 50c; per 10, \$3.50.

\section{ETDEANGFA}

\section{Paniculata Grandiflora}

Heads extra large; cream color in bud, then turning pure white, finally changing to bronze. 1 to 2 feet, $75 \mathrm{c}$. 


\section{Deciduous Shrubs}

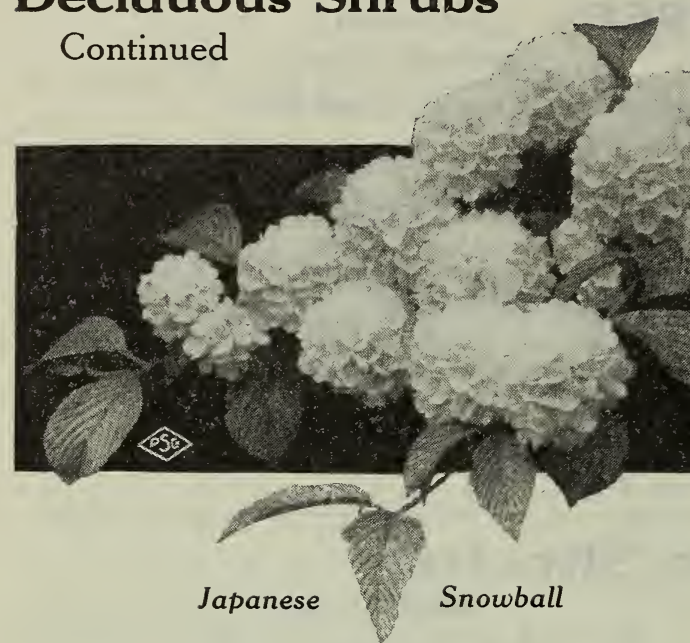

NEW HYDRANGEA

Arborescens Alba Grandiflora (known as "Snowball Hydrangea") -A grand addition to the summer flowering shrubs-flowers July and August. The flowers are large, similar to snowball in appcarance, conspicuously white; fine for single specimen or cut flowers.

Each, $\$ 1.00$

Paniculata Grandiflora.-One of the most desirable flowering shrubs; attains a height of 4 to 5 feet, flowering from July to November bearing immense panicles of bloom, a foot or more in length; color, creamy white with pink flush. Prune back in early spring, about half of previous year's growth; flowers are borne on the new wood. Hardy everywhere; good for cemetery planting.

2 to 3 feet, each, $25 \mathrm{c}$ to $50 \mathrm{c} ; 3$ to $4 \mathrm{feet}, 75 \mathrm{c}$ Tree shaped, each, $\$ 1.00$

\section{IIIACS}

Common Purple (Syringa Vulgaris)

Very fragrant, an old favorite. 3 to 4 feet, 50c; per 10, \$4.50.

\section{Common white}

(Syringa Vulgaris)

Same as above, flowers white. 3 to 4 feet, 50c; per 10, \$4.50.

\section{FINE NAMFD VARIFTIFS}

Grafted Standards, $6 \mathrm{ft}$. $\$ 1.25$ each.

Choice plants, 3 to 4 feet, each, 75c.

$$
\text { CIAs. } \mathbf{x} \text {-Single }
$$

A strong rapid grower; trusses large and loose, color reddish purple.

\section{MARIF IF GRAYM-Single}

Flowers large, beautiful creamy white; bush dwarf.

\section{Pale lilac.}

\section{MICFEI BUCFNER-Double}

PRES. GREVY-Double Ma

Magnificent; beautiful blue panicla; very

IUDWIG SPAFTH-Single

Very fine; trusses large; deep purple. IMME. IFMOINE-Double

White color: fine for winter forcing.

PRES. CARNOT-Double

Fine, lavender, with white center, late flowering.

\section{MOCK ORANGP (Philadelphus)}

3 to 4 feet, $50 \mathrm{c}$; per $10, \$ 4.00$

$$
\text { Grandiflora }
$$

Flowers large and slightly fragrant. Slender twig habit. Price, 3 to 4 feet, each, 50c; per $10, \$ 4.00$.

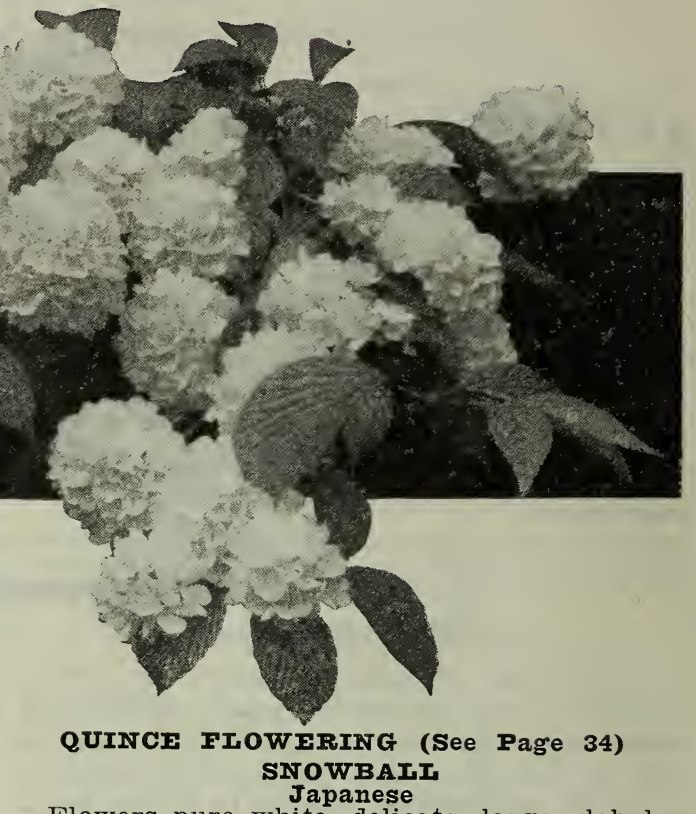

Flowers pure white, delicate, large globular heads, in May. 2 to 3 feet, 75c. See cut. Commoin

Flowers globular, pure white, in May. 3 to 4 feet, each, 50c; per 10, $\$ 4.00$.

\section{SCOTCF IROOM}

Rapid growing, hardy; trusses of yellow flowers in May. $50 \mathrm{c}$

\section{SMOKB TRFT}

Low growing and shrubby, flowers feathery, appearing like a cloud of smoke. $75 \mathrm{c}$ to $\$ 1.00$.

\section{Spiraeas}

Queen Alexandra-Soft, beautiful pink, free flowering, vigorous; a valuable new variety.

Peach Blossom-Dainty new pink of great beauty; good grower, free bloomer.

Anthony Waterer-A handsome shrub, that blooms about the close of June; flowers red. Clumps, each, $75 \mathrm{c}$

Billardi-Produces fine, rose-colored flowers, and blooms nearly all summer.

Strong clumps, each, 60c

Prunifolia, Bridal Wreath-The pretty double white flowers are in bunches of twos and threes, and usually expand about May 1.

Clumps, each, $75 \mathrm{c}$

Thunbergii-Of graceful habit; branches are slender and somewhat drooping; foliage yellowish-green; flowers small, white, appearing early.

Clumps, each, $\$ 1.00$

Van Houtte-The grandest of all the Spireas. It is a beautiful ornamental for the lawn at any season, but when in flower it is a complete fountain of white bloom, the foliage hardly showing. Perfectly hardy and an early bloomer.

2 to 3 feet, $60 \mathrm{c}$ to $75 \mathrm{c}$

\section{TAMARIX}

Elegant, fine flowering and handsome foliage. Flowers carmine-red. August, September. 3 to 4 feet, 50 c.

\section{WEIGEIIA}

Flowers white; bush tall and very graceful. $75 c$.

Flowers light pink, shrub compact and shapely. 75c.

Flowers red, one of the best. Slightly dwarf. $75 c$.

Leaves become silvery white. 75 . 


\section{Climbing Vines}

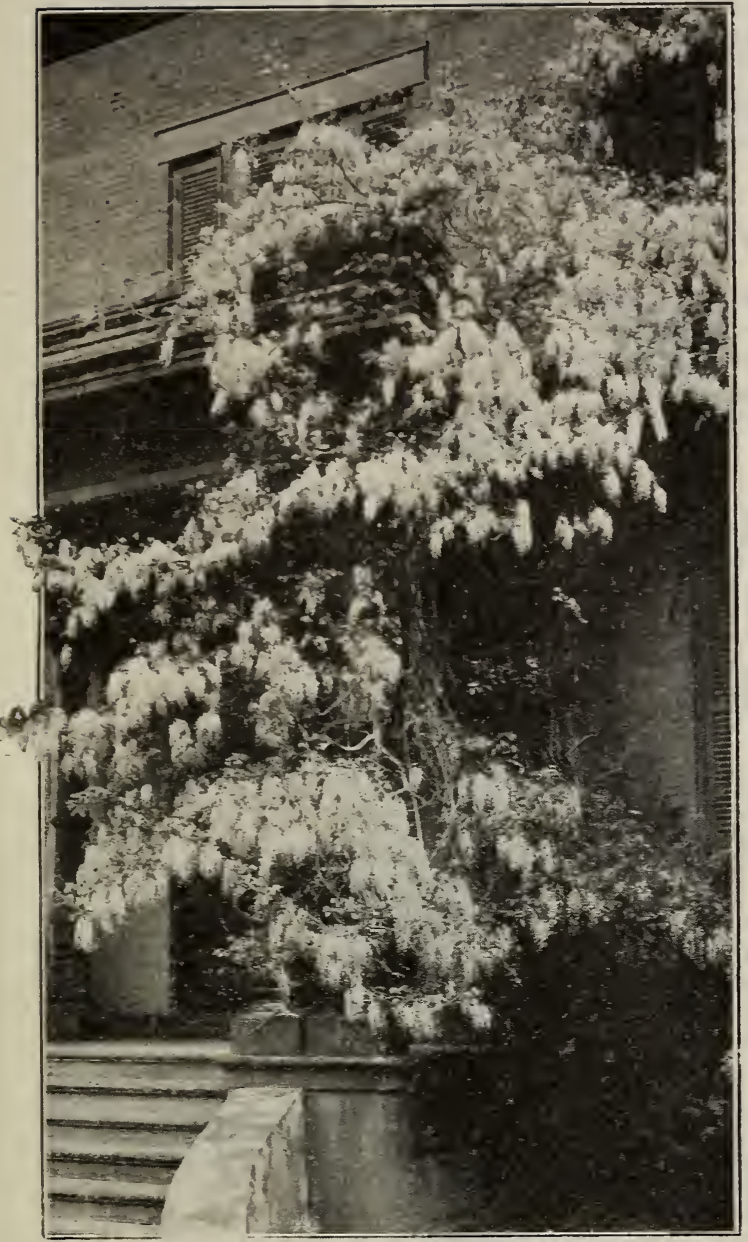

Wistaria

\section{AMPEIOPSIS}

Veitchii (Boston I $\mathbf{V}$ )

Leaves glossy green, coloring bronze in fall; flowers small; berries deep blue. 35c. Quinquefolia (Virginia Creeper)

Common American Ivy 35c.

BIGNONIA GRANDIFIORA (Trumpet Vine) Strong climber; decidious; flowers orangescarlet. $50 \mathrm{c}$.

$50 \mathrm{c}$

Evergreen, clinging; flowers canary yellow.

One of the most beautiful and useful climbers adapting themselves to every requirement. Their magnificent flowers, borne in greatest profusion in beautiful shades of lavenders, purples, reds and white, make them especially attractive. Clematis requires a rich loamy soil, but manure should not touch the roots. Cut out the weak and surplus branches in the spring, and tie the vine up well to its support. We offer the best of the hardy large flowering varieties.

Ramona-Beautiful lavender; best of its color

Montana-White, anemone-like flowers, May to July; very hardy, rapid grower.

Henry-Fine, large, creamy white flowers; a strong grower and very hardy.

Jackmani-Intense violet-purple, with a rich velrety appearance; distinctly veined. The most popular and finest Clematis we have.

Mad. Ed. Andre-A beautiful, new variety; flowers red, large and abundant.

Choice plants of above sorts, each, 60c; Large plants, each, $75 \mathrm{c}$ to $\$ 1.00$, postpaid

Clematis Paniculata-A strong, rapid and vigorous grower; it produces sheets of medium-sized, pure white flowers of the most pleasing fragrance; it is perfectly hardy and well adapted for covering trellises or fences.

Choice plants, each, $25 \mathrm{c}$ to $50 \mathrm{c}$; large, $40 \mathrm{c}$ to $60 \mathrm{c}$ Belgian

Flowers yellow, blotched with red above;

looms all summer, fragrant. $\mathbf{E a c h}, 50 \mathrm{C}$

Japanese

Evergreen; fragrant flowers, white changing yellow. rach, 35c.

\section{Hall's}

Evergreen, very popular; white turning to ing yellow. Fach, 50c.

IVY-Inglish

Large, thick, shining, leathery leaves. Each, $35 c$.

\section{JASMIII}

\section{Nudiforum}

Branches drooping, enveloped with bright yellow flowers before leaves appear. $\mathbf{3 a c h}$ $50 \mathrm{c}$.

Gardenia Flowered-Cape Jasmine

Free blooming, pure white flowers, star shaped; foliage delicate; evergreen. Fach, 50c.

\section{Wistaria}

W. Sinensis-Chinese Wistaria-One of the most elegant and rapid growing of all climbing plants; grows 15 to 20 feet in a season; has long pen. dulous clusters of pale blue flowers in May and June and in autumn.

Choice plants, each, $35 \mathrm{c}$ to $50 \mathrm{c}$; large, $75 \mathrm{c}$ to $\$ 1.50$

W. Multijuga-Similar to above, but flowers are darker.

W. Brachybotrys-White flowering. Each, $75 \mathrm{c}$ to $\$ 1.50$

Sach, $75 \mathrm{c}$ to $\$ 1.50$

\section{PORTLAND SEED COMPANY'S "Diamond" Fancy Lawn Mixture}

TO have a grood lawn the soil must be fine and rich, and well leveled. Then the best seed obtainable should be used. Plant any time from september until late spring, depending upon the weather and soll conditions. Raking in the seed is advisable, and rolling greatiy improves the turf. In watering jour lawn soak it deeply and not too often, as light watering every day brings the roots close to the surface, where they quickly burn or dry out. You must not expect to make a fine lawn with cheap seed. The best lawn grass mixture will cost more at first than the poorer substitute, but it will be found much cheaper and more satisfactory in the end. Our "Diamond Quality" Fancy Mized Grass Seed is prepared from the choicest recleaned Grass Seeds that have been carefully selected for their fineness and deep rooting, close growing habits and seasonable qualities, producing an ideal dense, velvety turf of lasting quality that remains green throughout the $y$ ear.

Price, per 1b., 45c., postpaid; freight or express, per 1b., 35c.;

Sow 1 pound to 400 square feet, 10 to 15 pounds to a 50-foot lot.

WRIT US FOR SPECIAI MIXTURES FOR TERRACES, SEADY PLACES, DRY OR WPT I. XID. 
See Our General Catalug for

\section{"Diamond Quality" SWEET PEAS}

FINEST, EARLIEST FLOWERS are produced from FALL PLANTINGS of our select varieties. Full information on request.

Join the OREGON SWEET PEA SOCIETY and win our handsome Solid Silver Challenge Cup (value \$60.00).

\section{INDEX}

A

\begin{abstract}
Allium
Anemones

Amaryllis

Araucaria

Aspidistra

Aucuba

Arborvitae

Ampelopsis

Almond

Althea

Asparagus

Azalea
\end{abstract}

Ash

B

Bulbs Tables

Begonias, Tuberou

Begonias, Rex

Bedding Plants

Bleeding Hearts

Bamboo

Berberry

Beech

Birch

Berries

Broom

C

Calla Lilies

Chinese Sacred Lily

Crocus

Cyclamen Buibs

Cyclamen Plants

Chinodoxa

Caladiums

Cannas

Camellia

Cryptomeria

Cedrus

Cyprus

Climbing and Trailing Plants. 6

Clematis $\ldots \ldots \ldots \ldots \ldots \ldots .63$

Chestnut

Crab, Flowering

D

Daffodils

Dahlias

Daphne

Draecena

Dogwood

$\ldots \ldots 24-25-26$

$\begin{array}{lll} & \mathbf{E} \\ \text { Erythronium } & \ldots \ldots \ldots \ldots \ldots & 17\end{array}$

Eranthus-Hyemalis $\ldots \ldots \ldots .17$

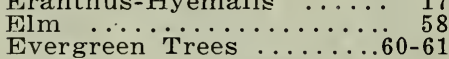

$\underset{\text { Evergreen Trees }}{\text { Evergren Shrubs } \ldots \ldots \ldots 60-61}$

$\mathbf{F}$

Feathered Hyacinths .... 14

Flower Pots $\ldots \ldots \ldots \ldots \ldots \ldots \ldots$. 43

FOR ALPHABETICAL LIST OF ROSES

Fritillaria Imperialis ..... 16

Ferns and Fern Balls.... 32

Filbert $\ldots \ldots \ldots \ldots \ldots \ldots, 59.6 \%$

Fruit Trees $\ldots \ldots \ldots \ldots \ldots$ 44-56

Grape Hyacinths $\ldots \ldots \ldots, 14$

Gladioli ............... 2

Geraniums

Grass Seed

Grass, Crimson Fountain.. 29

II

Hyacinths $\ldots \ldots \ldots \ldots \ldots 3-4-5$

House Plants ...........32-34

Hydrangea ........ 35-61-62

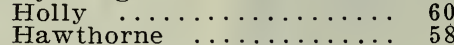

Hawthorne ............ 58

Himalaya Giant Berry ... 52

Hon Vines $\ldots \ldots \ldots \ldots \ldots \ldots{ }^{2}{ }^{2}$

Horseradish

Hyacinth Glasses ........ ${ }_{2}$

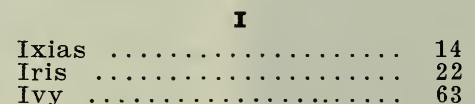

J

Jonquils …........ 12

Juniper ...........60-61

Jasminum ........... 63

Leucojum

I

Lilies $\ldots \ldots \ldots \ldots$ 18-19-20-21

Lily of valley .......

Lilac-Tree ........... 34

Lilac $\ldots \ldots \ldots \ldots \ldots \ldots \ldots 62$

Lauristinus ........... 61

Laburnum (Golden Chain). 58

Linden $\ldots \ldots \ldots \ldots \ldots \ldots .5 \%$

Locust $\ldots \ldots \ldots \ldots \ldots \ldots \ldots$

Maple ...........

Magnolia .............35-58

Mahonia Aquifolia

(Oregon Grape) …... 61

Mulberry A $_{\text {. }} \ldots \ldots \ldots \ldots$ 50-59

Mountain Ash $\ldots \ldots \ldots \ldots \ldots .6 \%$

Moss $\ldots \ldots \ldots \ldots \ldots \ldots \ldots . . \ldots \ldots$

N
Narcissi $\ldots \ldots \ldots \ldots$ 10-11-12-13-14
Nut Trees $\ldots \ldots \ldots \ldots \ldots .69-60$

$\mathbf{0}$

Oxalis $\ldots \ldots \ldots \ldots \ldots \ldots, 17$

Ornithogalum $\ldots \ldots \ldots \ldots \ldots$
Oak $\ldots \ldots \ldots \ldots \ldots$
Paeonies ........... 28

Perennials $\ldots \ldots \ldots \ldots \ldots \ldots .30$

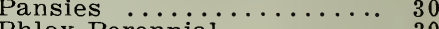

Phlox-Perennial $\ldots \ldots \ldots \ldots . . . .30$

Pampas Grass .......... 29

Parrots Feather ......... 29

Palms .............. 38

Persimmon $\ldots \ldots \ldots \ldots \ldots \ldots{ }^{3} 34$

Prunus $\ldots \ldots \ldots \ldots \ldots \ldots \ldots \ldots \ldots \ldots \ldots$ 35-59

Pine ............. 61

Privet $\ldots \ldots \ldots \ldots \ldots \ldots \ldots \ldots, 61$

Poplar $\ldots \ldots \ldots \ldots \ldots \ldots \ldots, 5 \% \ldots$

Pruning Tools .......... 35

Plant Stakes ........... 35

Q

$\mathbf{R}$

Ranunculus .......... 17

Roses ................. to 43

Rose Tubes .......... 43

Rubber Plant .......... 34

Rhododendron ........ 61

Rhubarb ............ 57

Raffia ............... 35

$\mathbf{s}$

Scilla ............. 17

Snowdrops $\ldots \ldots \ldots \ldots \ldots \ldots{ }_{14}$

Shrubs-Deciduous $\ldots \ldots 6$ 61-62

Sparaxis ............. 17

Spruce ............ 61

Strawberries ......... $54-55$

Spray Calendar ........ 57

Sprayer-"Ideal" ......... 42

Snowball ............. 62

Sciadopitys Verticillati .. 34

Spiraea ............ 62

St. Johns-Wort .......... 29

Tulips ..........6.

Tulip Beds $\ldots \ldots \ldots \ldots \ldots \ldots \ldots \ldots, 6-8$

Tritelia Uniflora .......... 17

Trumpet Vine .......... 47

Tulip Tree .......... 59

Tamarix ...............6. 62

Tree Paeony ........... 28

Trees-Deciduous ….....58-59

Tritoma ("Red Hot Poker") 47

Thuja Obtusa ........... 34

Vegetable Roots and

Plants ...........56-57

$\mathbf{w}$

Water Lilies .......... 29

Wistaria $\ldots \ldots \ldots \ldots \ldots$ 6 63

Walnuts ........... 59

Weigelia Wrees $\ldots \ldots \ldots \ldots \ldots .6 \% 60$

$\mathbf{Y}$
Yucca $\ldots \ldots \ldots \ldots \ldots \ldots \ldots \ldots$

HOLLIES FOR HEDGES Extra choice, all sizes up to 5 feet. 


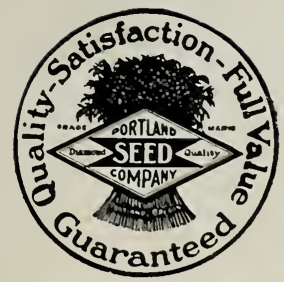

"DIAMOND

QUALITY

We are the largest dealers and carry the most complete stock of Fertilizers in the Northwest. They are of guaranteed analysis, conforming to the standards required by the State Laws of Oregon.

Ask for our Special Fertilizer Catalog, containing valuable information on the use and application of Fertilizer.

\begin{tabular}{|c|c|c|c|c|c|c|}
\hline FERTILIZER & Nitrogen & $\begin{array}{c}\text { Available } \\
\text { Phosphoric } \\
\text { Acid }\end{array}$ & Potash & $\begin{array}{l}\text { Per } \\
100 \\
1 \mathrm{bs} .\end{array}$ & $\begin{array}{l}\text { Per } \\
224 \\
\text { lb. } \\
\text { Bag }\end{array}$ & $\begin{array}{l}\text { Per } \\
\text { Ton }\end{array}$ \\
\hline 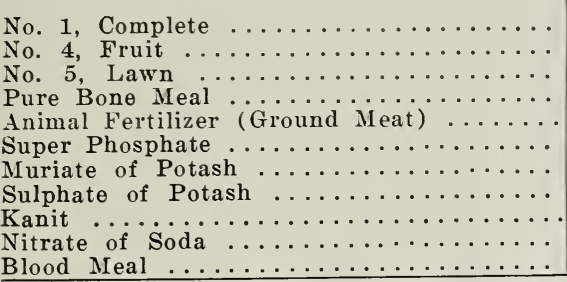 & 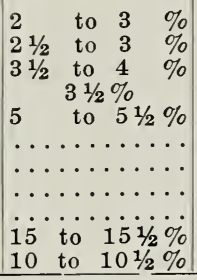 & 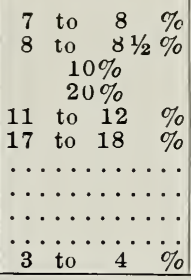 & 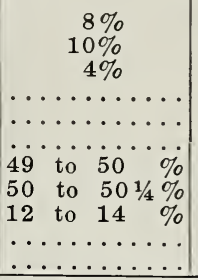 & $\begin{array}{c}\$ 1.90 \\
2.00 \\
2.25 \\
1.85 \\
1.75 \\
1.60 \\
3.25 \\
3.50 \\
1.50 \\
3.25 \\
3.25 \\
\end{array}$ & $\mid$\begin{tabular}{|c|}
$\cdots$ \\
$\cdots \cdots$ \\
$\cdots \cdots$ \\
$\cdots \cdots$ \\
$\cdots 6.50$ \\
7.25 \\
$2.50 \mid$ \\
$\cdots \cdots$ \\
$\cdots \cdots$
\end{tabular} & $\begin{array}{r}\$ 36.00 \\
38.00 \\
35.00 \\
32.00 \\
29.00 \\
54.00 \\
60.00 \\
20.00 \\
55.00 \\
\ldots\end{array}$ \\
\hline
\end{tabular}

We are general agents for the German Kali Works, and can supply their Potash in any quantity. Write for prices on car lots.

BEST FERTILIZERS FOR SPECIAL PURPOSES.

\begin{tabular}{|c|c|c|c|}
\hline & $\begin{array}{c}\text { POUNDS } \\
\text { PER ACRE }\end{array}$ & $\begin{array}{l}\text { FERTILIZER } \\
\text { TO USE }\end{array}$ & WHEN TO APPLY. \\
\hline 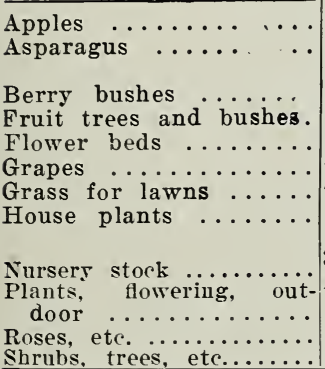 & 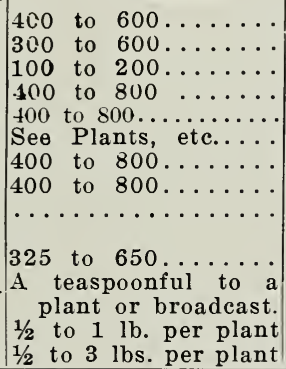 & 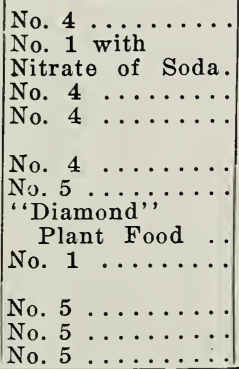 & $\begin{array}{l}\text { Fall or early spring. } \\
\text { Spring. } \\
\text { Fall or Winter preferred, or early spring. } \\
\text { Fall or Winter preferred, or early spring. } \\
\text { Fall or early spring. } \\
\text { Apply fiill or spring, broadcast. } \\
\text { Directions on each package. } \\
\text { Early spring. } \\
\text { Worked in the top soil when cultivating or } \\
\text { making beds. } \\
\text { Fall, winter or spring. }\end{array}$ \\
\hline
\end{tabular}

\section{PLANTING TABLES}

\section{DISTANCES RECOMMENDED FOR PLANTING.}

Apples (Standard) $\quad \ldots \ldots \ldots \ldots 25$ to $40 \mathrm{ft}$. each way Pears (Standard) ..............20 to $35 \mathrm{ft}$. each way

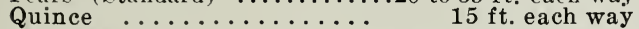

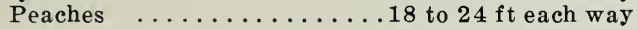

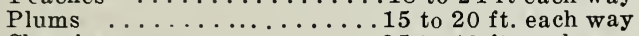
Cherries ............25 to $40 \mathrm{ft}$. each way

Blackberries ......... $6 \mathrm{ft} . \mathrm{x} 4 \mathrm{ft}$.

Raspberries .......... $6 \mathrm{ft.} \times 3 \mathrm{ft}$.

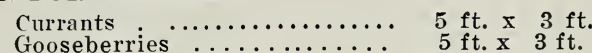

Strawberries (hills) $\cdots \cdots \cdots \cdots, 36$ in. $x 18$ in.

Strawberries (matted rows).. 48 in. $x 12$ in.

Grapes ................................. 8 to 10 x $12 \mathrm{ft}$.

Asparagus ........... $4 \times 1 \mathrm{ft}$.

Rhubarb ............ $4 \times 2 \mathrm{ft}$

NUMBER OF PLANTS PER ACRE AT VARIOUS DISTANCES.

In planting trees the greater distance should be given in the richer soils.

\begin{tabular}{|c|c|c|c|c|c|c|c|}
\hline TANCE & APART. & $\begin{array}{l}\text { Square } \\
\text { Method. }\end{array}$ & $\begin{array}{c}\text { Triangu- } \\
\text { lar. }\end{array}$ & DISTANCE APART. & & $\begin{array}{l}\text { Square } \\
\text { Method. }\end{array}$ & $\begin{array}{c}\text { Triangu- } \\
\text { lar. }\end{array}$ \\
\hline oot apar & t each way & $\ldots \ldots 43,560$ & 50,300 & 15 feet apart each way & & 193 & 223 \\
\hline et apart & t each way & $.10,890$ & 12,575 & 16 feet apart each way & & 170 & 196 \\
\hline feet apart & t each way & - 2,722 & 3,143 & 20 feet apart each way & & 108 & 125 \\
\hline feet apart & t each way & $\ldots \ldots \ldots 1,210$ & 1,397 & 25 feet apart each way & & 70 & 81 \\
\hline 9 feet apart & t each way & $\ldots \ldots$ & 620 & 30 feet apart each way & & 48 & 55 \\
\hline 0 feet apar & t each way & $\ldots \ldots$ & 502 & 40 feet apart each way & & 27 & 31 \\
\hline
\end{tabular}

RULE SQUARE METHOD-Multiply the distance in feet between the rows by the distance the plantg are apart in the rows; this gives the number of square feet for each plant or hill; divided into the number of feet in an acre $(43,560)$ gives the number of plants or trees to an acre.

RULE TRIANGULAR METHOD-Divide the number required to the acre "square method" by the lecimal .866. The result will be number of plants required to the acre by triangular planting.

\section{LEWIS PLANTING BOARD}

When your stakes are placed, where the trees are to be set, take an inch board 6 inches wide and 6 feet 6 inches long, bore a $3 / 4$ inch hole in the center of each end and cut a notch in the side at center that your trees will fit into. Now take two small stakes 12 inches long that will slip easily through the end holes, place the center notch around the stake where the tree is to stand, place a small stake through each of the holes in the ends, now lift your board leaving the small stakes in the ground, dig the hole, replace the board over the stakes and set the tree in the notch, plan it in this position and your orchard will "line up " perfectly. 


\section{"DIAMOND QUALITY" NURSERY STOCKS GROWN IN OREGON}

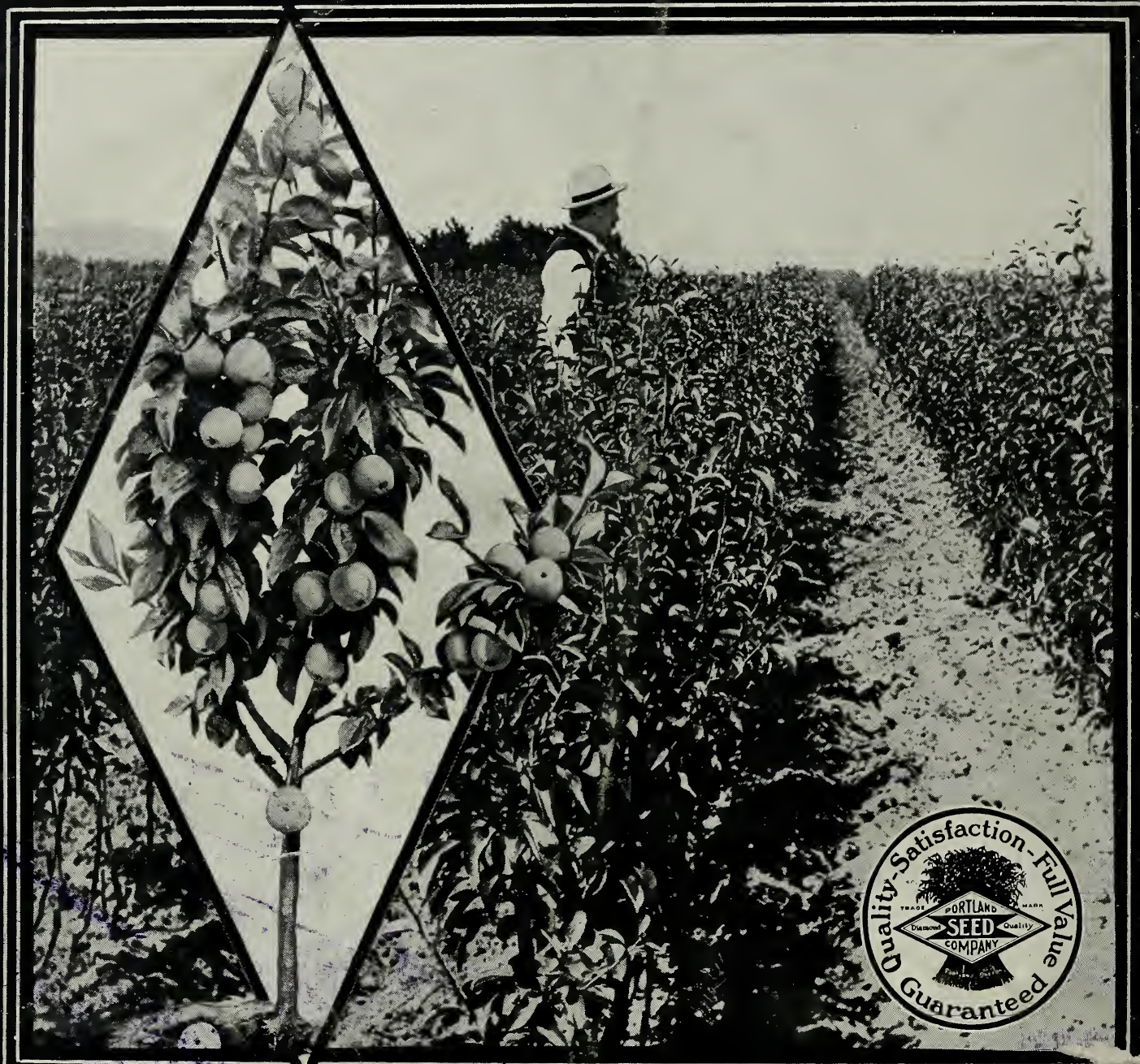

TWENTY-FIVE THOUSAND DWARF FRUIT TREES, TWO YEARS OLD-(Photo July, 1911) - Dwarf Frees are best for Home Gardens See hage 48

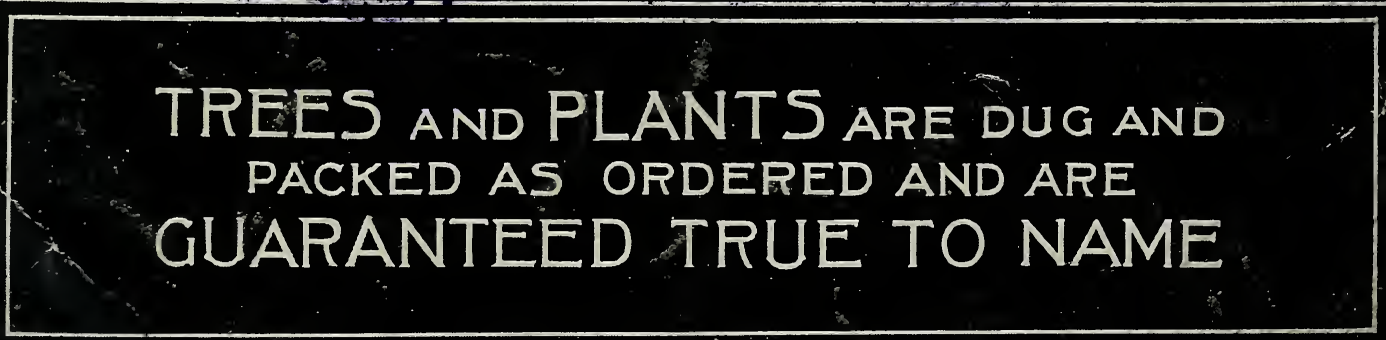

